\title{
ANÁLISE DE ALTERNATIVAS ESTRUTURAIS PARA EDIFÍCIOS EM CONCRETO ARMADO
}

Augusto Teixeira de Albuquerque

Dissertação apresentada à Escola de Engenharia de São Carlos, da Universidade de São Paulo, como parte dos requisitos para obtenção do título de Mestre em Engenharia de Estruturas.

ORIENTADOR: Prof. Dr. Libânio Miranda Pinheiro

São Carlos

1999 
Class. TESE

108202

Ficha catalográfica preparada pela Seçāo de Tratamento da Informação do Serviço de Biblioteca - EESC/USP

Albuquerque, Augusto Teixeira

Análise de alternativas estruturais para

A345a edifícios em concreto armado / Augusto Teixeira de Albuquerque. -- São Carlos, 1998.

Dissertação (Mestrado) -- Escola de Engenharia de São Carlos-Universidade de São Paulo, 1998.

Área: Engenharia de Estruturas.

Orientador: Prof. Dr. Libânio Miranda Pinheiro.

1. Concreto armado. 2. Sistemas estruturais. 3. Projeto - custos. I. Título. 
Candidato: Engenheiro AUGUSTO TEIXEIRA DE ALBUQUERQUE

Dissertação defendida e aprovada em 08-02-1999 pela Comissão Julgadora:

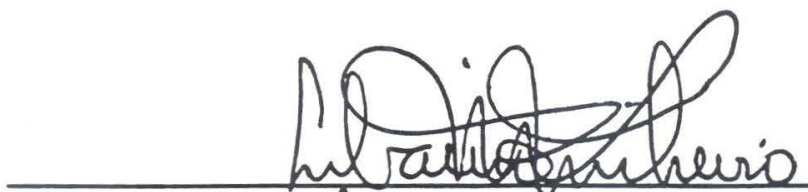

Prof. Doutor LIBÂNIO MIRANDA PINHEIRO (Orientador)

(Escola de Engenharia de São Carlos - Universidade de São Paulo)

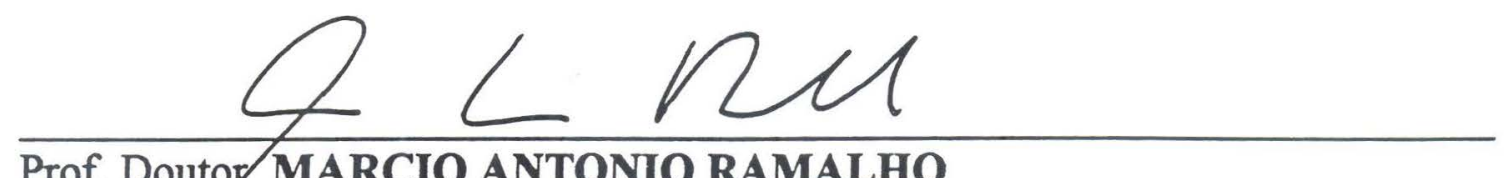

\section{Prof. Doutor MARCIO ANTONIO RAMALHO}

(Escola de Engenharia de São Carlos - Universidade de São Paulo)
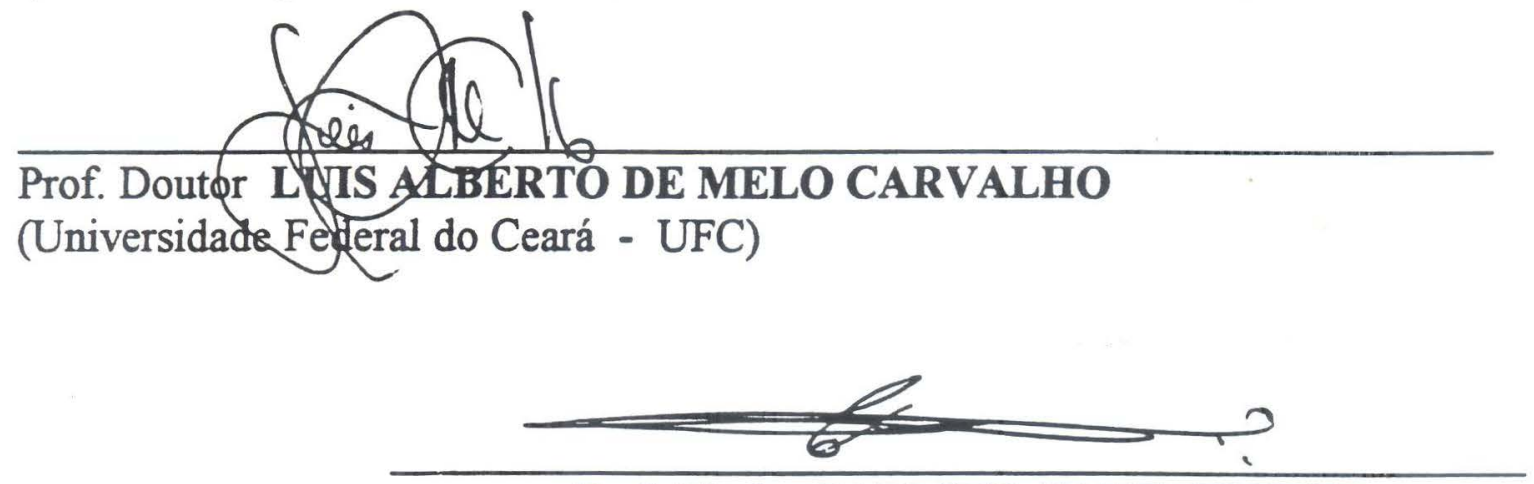

Prof. Titular CARLITO CALIL JUNIOR

Coordenador da Área de Engenharia de Estruturas

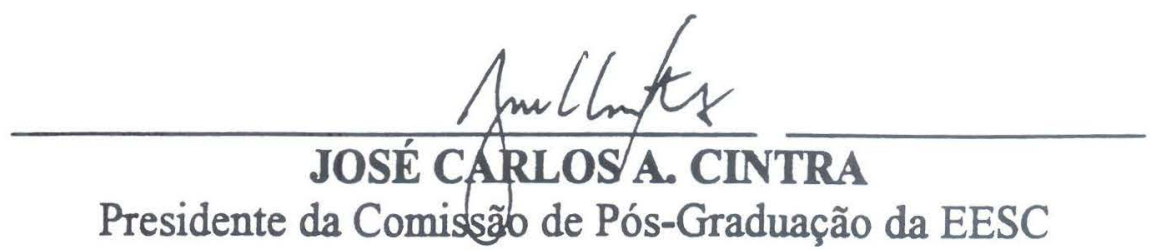




\section{AGRADECIMENTOS}

Aos meus pais, pelo apoio total e irrestrito em todas as fases da minha vida, pela educação e pelo exemplo de vida.

À minha esposa Luciana, que esteve ao meu lado, sempre incentivadora, em todos os momentos.

Ao professor Libânio Miranda Pinheiro, pela orientação objetiva e dedicada, pela confiança depositada e pela amizade.

Aos engenheiros Adízio Lima, Argemiro Brito Monteiro da Franca, Carlos Fujita, Dácio Carvalho, Hélder Martins e Luis Alberto Carvalho, pelas valiosas contribuições.

Aos professores, colegas e funcionários, em especial à bibliotecária Maria Nadir Minatel, do Departamento de Engenharia de Estruturas da EESC-USP.

Ao professor Francisco Fausto de Albuquerque (tio Fausto), pela zelosa e atenciosa correção gramatical.

Aos amigos Alex Sander Clemente de Souza, Flávio Craveiro Cunto e Osvaldo Gomes de Holanda Junior, pelo apoio desde minha chegada a São Carlos.

À CAPES e à FAPESP, pelas bolsas de mestrado. 


\section{SUMÁRIO}

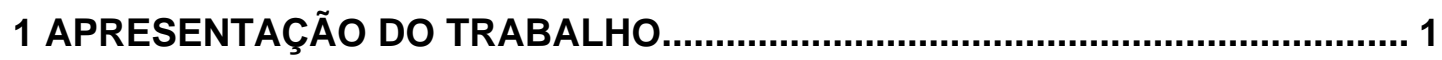

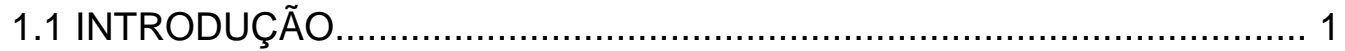

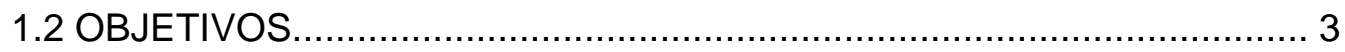

1.3 APRESENTAÇÃO DO EDIFÍCIO-EXEMPLO.................................... 4

1.4 AÇÕES CONSIDERADAS ........................................................... 4

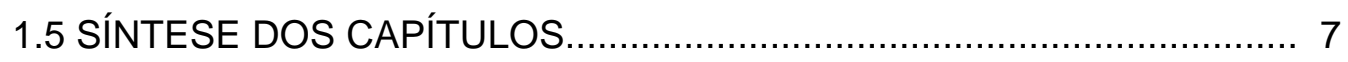

2 ETAPAS DO PROJETO ESTRUTURAL..................................................... 9

2.1 CONCEPÇÃO DA ESTRUTURA.................................................. 9

2.2 CARREGAMENTO DA ESTRUTURA ............................................. 10

2.3 PRÉ-DIMENSIONAMENTO......................................................... 10

2.3.1 Lajes........................................................................... 10

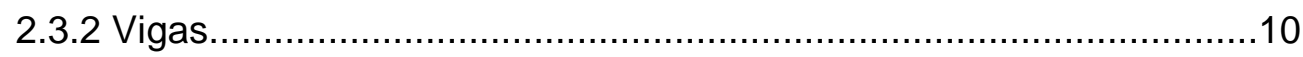

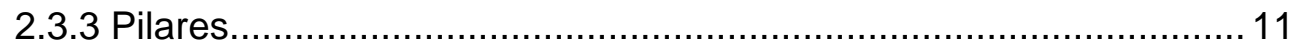

2.4 VERIFICAÇÃO DOS PARÂMETROS DE INSTABILIDADE.................. 11

2.5 DETALHAMENTO DO PROJETO..................................................14

2.6 VERIFICAÇÃO DOS CONSUMOS.................................................14

2.6.1 Espessura média..................................................................14

2.6.2 Taxa de aço...................................................................... 14

2.6.3 Taxa de aço II.................................................................... 15

2.6.4 Taxa de forma........................................................................ 15

2.7 RECOMENDAÇÕES PARA ESTRUTURAÇÃO ............................. 15

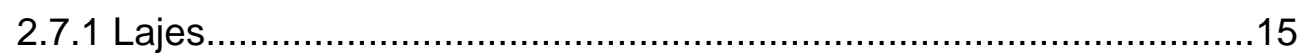

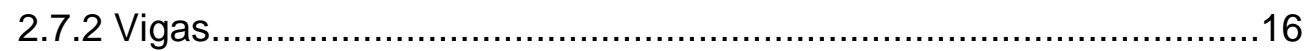

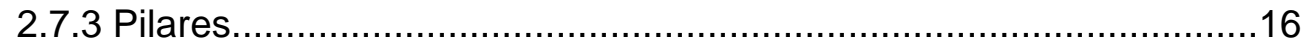

2.8 QUALIDADE DA SOLUÇÃO ADOTADA............................................17

2.9 SOBRE O SOFTWARE TQS ....................................................... 19

3 ESTRUTURA CONVENCIONAL COM LAJES MACIÇAS.................................. 21

4 ESTRUTURA CONVENCIONAL COM LAJES NERVURADAS............................ 24

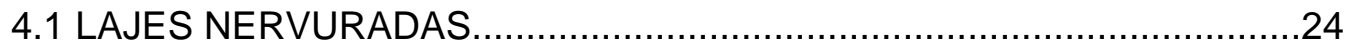

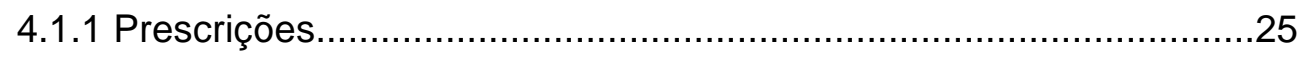

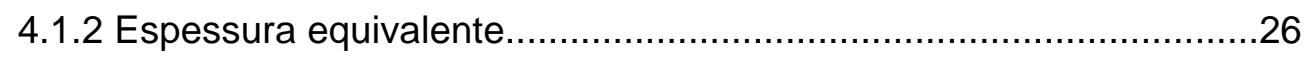

4.1.3 Processo simplificado........................................................ 
Analogia de grelha................................................................... 29

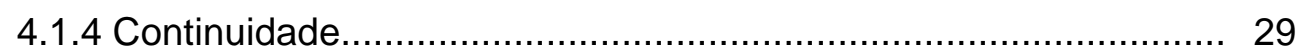

4.2 LAJES PRÉ-MOLDADAS ..............................................................

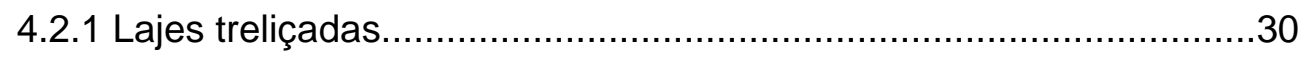

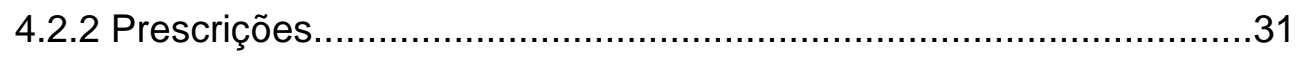

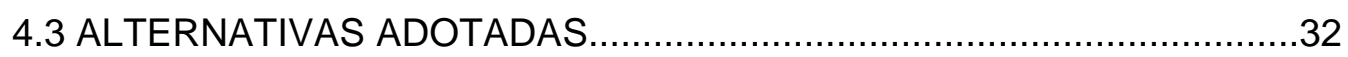

4.3.1 Alternativa utilizando caixotes de propileno................................... 34

4.3.2 Alternativa utilizando tijolos como material inerte........................... 37

4.3.3 Alternativa utilizando lajes pré-fabricadas................................... 39

5 ESTRUTURA COM LAJE LISA NERVURADA..............................................44

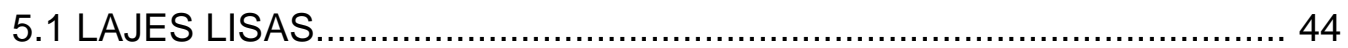

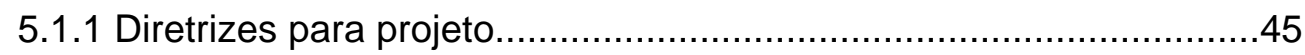

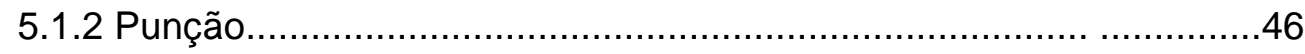

5.1.3 Modelo de cálculo das lajes lisas...............................................48

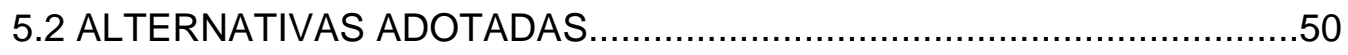

5.2.1 Alternativa utilizando caixotes de propileno...................................53

5.2.2 Alternativa utilizando tijolos como material inerte........................... 55

6 ESTRUTURA UTILIZANDO PROTENSÃO.................................................... 57

6.1 PROTENSÃO COM MONOCORDOALHAS ENGRAXADAS................. 57

6.1.2 Método do balanceamento de cargas......................................... 59

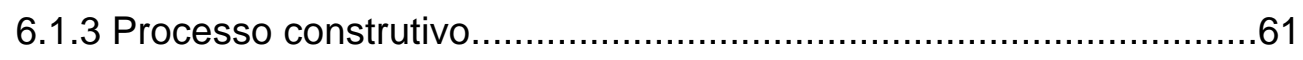

6.1.4 Exemplo de utilização............................................................62

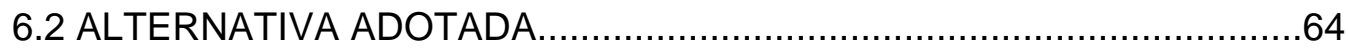

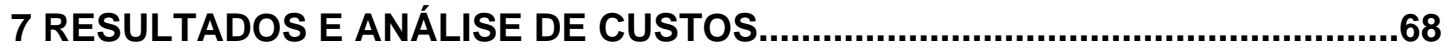

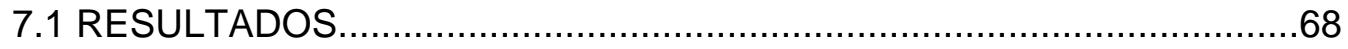

7.2 ANÁLISE DE CUSTOS............................................................

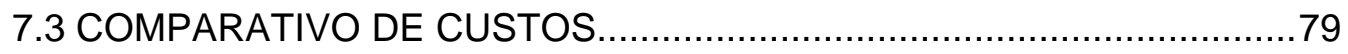

7.4 VERIFICAÇÃO DE PARTE DOS RESULTADOS ............................... 79

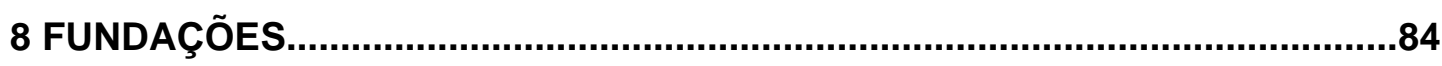

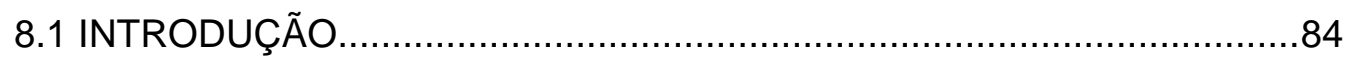

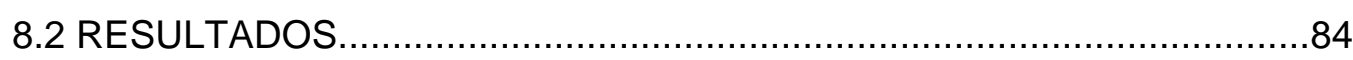

8.3 COMPARATIVO DE CUSTOS .................................................95

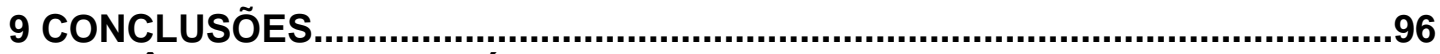

REFERÊNCIAS BIBLIOGRÁFICAS

BIBLIOGRAFIA COMPLEMENTAR 


\section{RESUMO}

ALBUQUERQUE, A.T. (1998). Análise de alternativas estruturais para edifícios em concreto armado. São Carlos, 1998. 97p. Dissertação (Mestrado) - Escola de Engenharia de São Carlos, Universidade de São Paulo.

Embora muitas vezes a escolha do sistema estrutural de um edifício seja influenciada por imposições arquitetônicas, por rotinas construtivas ou ainda pela infra-estrutura da região, cabe ao engenheiro de estruturas buscar, dentro das condições impostas, a alternativa estrutural que garanta maior economia.

Com este trabalho pretende-se estabelecer uma relação entre os índices de consumo de materiais (concreto, aço e forma) e os respectivos custos, dentre vários sistemas estruturais em concreto armado. Para tal será analisado um edifício residencial, adotando-se várias opções, entre as quais: estrutura convencional com lajes maciças, lajes nervuradas e lajes pré-fabricadas, estrutura com laje lisa nervurada e estrutura com laje protendida, utilizando monocordoalhas engraxadas.

Para que o levantamento de custos de cada alternativa seja o mais real possível, serão levados em consideração: materiais, mão-de-obra, tempo de execução e equipamentos necessários.

Palavras-chave: concreto armado; sistemas estruturais; projeto - custos. 


\begin{abstract}
ALBUQUERQUE, A.T. (1998). Structural alternatives analisysis in reinforced concrete buildings. São Carlos, 1998. 97p. Dissertação (Mestrado) - Escola de Engenharia de São Carlos, Universidade de São Paulo.
\end{abstract}

Despite the fact that many times the choice of the structural system of a building is influenced by architectural especifications, constructives processes or regional capability, the structural engineering has to look for, according to the conditions, the alternative that guarantees the lower cost.

This work aims to establish a relation between the material consumption (concrete, stell and formwork) and the structural system cost, among the structural alternatives in reinforced concrete. It will be analised a residential building, considering some options: two-way slab systems with beams, waffle slabs, precast slabs, flat plate waffle slabs and prestressed slabs with unbonded tendons.

In the cost computation, for each alternative it will be considered: materials, equipment, construction time and workmanship.

Keywords: reinforced concrete; structural systems; project - costs. 


\section{APRESENTAÇÃO DO TRABALHO}

\subsection{INTRODUÇÃO}

Os primeiros edifícios com estrutura de concreto armado foram concebidos utilizando-se lajes maciças e, posteriormente, lajes pré-moldadas. Apresentavam distâncias relativamente pequenas entre pilares, da ordem de quatro metros. Agiam como fatores limitantes: a resistência do concreto, várias hipóteses simplificadoras na modelagem estrutural e o comportamento do próprio sistema estrutural. Com a evolução da tecnologia de construção e da informática, foi possível o emprego de concretos mais resistentes, análises mais refinadas para o cálculo e a utilização de novas opções estruturais: lajes nervuradas, lajes lisas e protensão em estruturas usuais de edifícios, por exemplo. Essas evoluções permitiram uma diversificação maior das peças de concreto e possibilitaram soluções mais arrojadas para os edifícios.

Ao fazer a concepção estrutural, o engenheiro tem de ter em mente vários aspectos, tais como: manter a estética e a funcionalidade do projeto arquitetônico, idéia aproximada dos esforços atuantes na estrutura, métodos construtivos e custos. A escolha do sistema estrutural de um edifício, em geral, é influenciada por imposições arquitetônicas, por rotinas construtivas ou ainda pela infra-estrutura da região. Mesmo assim, o engenheiro de estruturas tem de buscar, entre todas as possibilidades, a estruturação mais econômica para o seu projeto.

De acordo com COSTA (1997), a evolução do processo construtivo começa pela qualidade dos projetos, e entre os projetos elaborados para a construção civil, destaca-se o estrutural. $O$ projeto estrutural, individualmente, responde pela etapa de maior representatividade no custo total da construção (15\% a $20 \%$ do custo total). Justifica-se então um estudo prévio para a escolha do sistema estrutural a ser adotado, pois sabe-se que uma redução de $10 \%$ no custo da estrutura pode representar, no custo total, uma diminuição de 2\%. Em termos práticos, $2 \%$ do custo total corresponde à execução de toda etapa de pintura ou a 
todos os serviços de movimento de terra, soleiras, rodapés, peitoris e coberta juntos.

O conceito de estrutura econômica também evoluiu ao longo dos anos. Em um primeiro instante, havia uma preocupação de se trabalhar com as seções mais esbeltas possíveis; hoje em dia a atenção está voltada para a padronização das formas, que facilita a produtividade da mão-de-obra e o reaproveitamento, e para os processos construtivos que serão usados. Isso porque houve uma conscientização dos projetistas de que o custo de uma estrutura não se resume ao do concreto e do aço, tendo de ser levados em consideração também a forma (representa em média $30 \%$ do custo da estrutura), o tempo de execução (retorno financeiro), outros materiais necessários e ainda a mão-de-obra empregada.

Segundo AALAMI (1994), "a economia é alcançada através de repetições, simplicidade dos detalhes, formas razoáveis e provisões para uma fácil instalação."

Segundo ABECE (1998), "a padronização dos materiais é, sem dúvida, pré-requesito importantíssimo para a otimização dos processos construtivos. No contexto internacional, ela é condição básica para o alcance de menores custos, alta produtividade e melhor qualidade. Além disso, é através dela que atingiremos alto grau de industrialização nas obras, transformando-as, como ocorre em outros setores da economia, em uma linha de montagem, obtendo-se a partir daí ganho de escala, melhor produtividade da mão-de-obra e mais competitividade.

Especificamente nas estruturas de concreto armado, a padronização de elementos traz benefícios intrínsecos que propiciam grandes ganhos, não só na execução da estrutura, mas também para o contexto global da obra. Isso ocorre porque com a estrutura padronizada, todos os outros elementos que serão construídos sobre ela seguem automaticamente o padrão pré-estabelecido no projeto estrutural."

Vários trabalhos têm sido feitos isoladamente sobre os sistemas estruturais usuais. Nota-se porém uma carência na literatura técnica de comparações entre eles, que sirvam de subsídio aos profissionais e ao meio acadêmico, para a concepção estrutural. Nota-se também que vários trabalhos abordam fatores econômicos apenas em função dos consumos de um determinado sistema estrutural, quando na realidade o custo tem de ser composto de uma 
maneira mais complexa, levando-se em consideração: mão-de-obra, tempo de execução e recursos necessários à execução.

Diante disso, neste trabalho pretende-se elaborar uma comparação de quantitativos e de custos, para servir de referência ao se fazer um anteprojeto. Não se pretende indicar uma solução ideal, mas apresentar resultados para um determinado edifício e também demonstrar a viabilidade deste tipo de estudo para o dia-a-dia dos escritórios, já que se dispõe de softwares poderosos, que minimizam o tempo de cálculo, de detalhamento e de orçamento dos projetos, viabilizando a análise de diversas alternativas.

A partir de um edifício-exemplo, serão concebidas diversas opções para o projeto estrutural, entre as quais: estrutura convencional com lajes maciças, nervuradas e pré-moldadas, estrutura com vigamento somente nas bordas (lajes lisas) e estrutura utilizando protensão. Cada alternativa será analisada, dimensionada e detalhada por inteiro, considerando lajes, vigas, pilares e fundações, levando-se em conta todas as ações atuantes, inclusive o vento. Para tal será utilizado o software TQS, que é usado em vários escritórios de projeto de estruturas do país.

\subsection{OBJETIVOS}

Os principais objetivos deste trabalho são:

- Fazer, para cada opção estrutural adotada, uma pequena revisão bibliográfica, descrevendo suas características, vantagens e desvantagens;

- Estabelecer alguns critérios para uma estruturação econômica;

- Estabelecer relações entre os consumos (concreto, aço e forma) e os custos das várias opções. Nos custos serão levados em consideração: consumo de materiais, recursos necessários para execução, tempo de execução e mão-de-obra. 


\subsection{APRESENTAÇÃO DO EDIFÍCIO EXEMPLO}

O edifício-exemplo foi cedido gentilmente pelo escritório Dácio Carvalho Projetos Estruturais S/C Ltda. Trata-se do projeto do Condomínio Costa Marina, de autoria do escritório Roger Freire Arquitetura e Engenharia, e de propriedade da construtora Colmeia Ltda, todos situados em Fortaleza/CE.

Trata-se de um edifício residencial, com dois apartamentos por pavimento (cada um com área útil de $105 \mathrm{~m}^{2}$ ), e, a partir da arquitetura do pavimento-tipo, foram feitas pequenas modificações, com o intuito de deixar os apartamentos simétricos, como se indica na figura 1.1. Para o estudo foi considerado hipoteticamente que o edifício tem vinte pavimentos, todos iguais ao tipo, e com uma distância de piso a piso igual a 2,88m, resultando em uma edificação com altura total de 57,6m.

Embora tenha importância considerável para a concepção estrutural, não foi considerada a existência de outros pavimentos como: coberta, mezanino, pilotis e subsolo. Esses pavimentos influenciam principalmente a posição dos pilares, que atravessam todos os pavimentos, e definem, por exemplo, a disposição das vagas de garagem, do hall de entrada, do salão de festas e da caixa-d'água.

\subsection{AÇÕES CONSIDERADAS}

De acordo com a revisão da NB-1 (1997), devem ser consideradas todas as ações que possam produzir efeitos significativos para a segurança da estrutura em questão, levando-se em conta os possíveis estados limites últimos e os de serviço.

"Ações permanentes são as que ocorrem com valores praticamente constantes durante toda a vida da construção. Também são consideradas como permanentes as ações que crescem no tempo tendendo a um valor limite constante. As ações permanentes são consideradas com seus valores representativos mais desfavoráveis para a segurança."

"As ações permanentes diretas são constituídas pelo peso próprio da estrutura e pelos pesos dos elementos construtivos fixos e das instalações permanentes." 


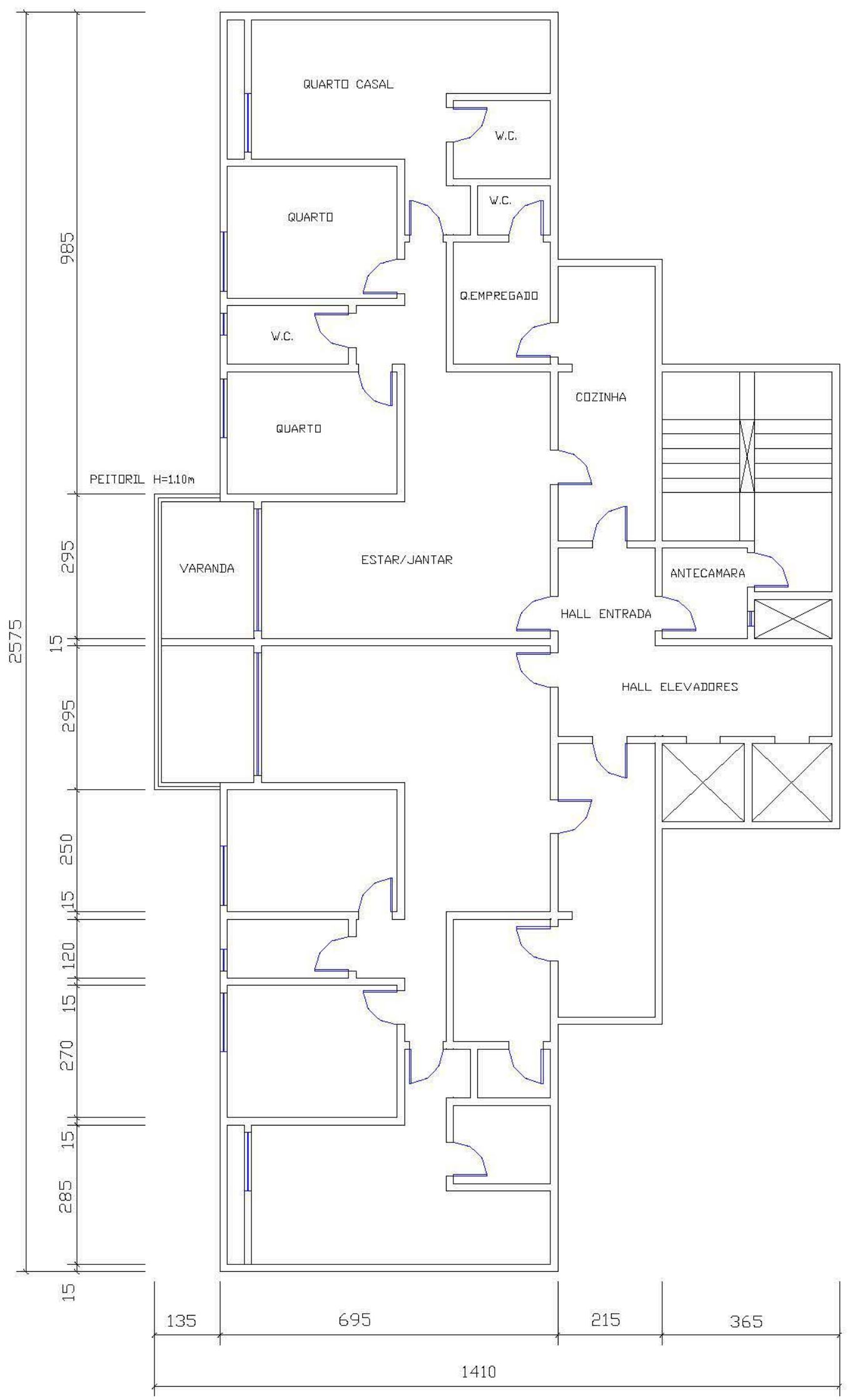

FIG. 1.1 - Pavimento-tipo do Condomínio Costa Marina (unidades: cm). 
"As ações permanentes indiretas são constituídas pelas deformações impostas por:

- retração do concreto;

- fluência do concreto;

- deslocamentos de apoio;

- imperfeições geométricas;

- protensão."

"As accões variáveis diretas são constituídas pelas cargas acidentais previstas para o uso da construção, pela ação do vento e da chuva, devendo-se respeitar as prescrições feitas por normas específicas."

Apresentam-se em seguida os valores de pesos específicos, cargas acidentais e características do vento, que serão utilizados para a composição das ações.

De acordo com a norma NBR 6120 (1980) - Cargas para Cálculo de Estruturas de Edificações, utilizaram-se como pesos específicos dos materiais em $\mathrm{kN} / \mathrm{m}^{3}$ :

- Tijolo cerâmico furado

- Concreto armado 25

- Areia com umidade natural. 17

Utilizaram-se como cargas acidentais em $\mathrm{kN} / \mathrm{m}^{2}$ :

- Pisos residenciais (dormitório, sala, copa, cozinha e banheiro) $.1,5$

- Pisos residenciais (despensa, área de serviço e lavanderia)... $.2,0$

- Escadas sem acesso público.

Ao longo dos parapeitos e balcões devem ser consideradas aplicadas uma carga horizontal de $0,8 \mathrm{kN} / \mathrm{m}$ na altura do corrimão e uma carga vertical mínima de $2 \mathrm{kN} / \mathrm{m}$. 
De acordo com a prática já exercida em vários escritórios, utilizou-se em todas as lajes uma carga permanente de $1 \mathrm{kN} / \mathrm{m}^{2}$ referente a revestimento e pavimentação.

As ações do vento foram avaliadas de acordo com a NBR 6123 (1987) - Forças Devidas ao Vento em Edificações, e, para o cálculo da velocidade característica do vento, adotou-se:

- Velocidade básica $\mathrm{V}_{0}=30 \mathrm{~m} / \mathrm{s}$, por se tratar de uma edificação na cidade de Fortaleza/CE;

- Fator topográfico $S_{1}=1,0$, considerando-se que o terreno seja plano ou fracamente acidentado;

- Rugosidade do terreno, dimensões da edificação e altura sobre o terreno: $\mathrm{S}_{2}=0,92$; em se tratando de centro de grande cidade, classifica-se como categoria $\mathrm{V}$, e como classe $\mathrm{C}$ porque é uma edificação na qual a maior dimensão excede $50 \mathrm{~m}$;

- Fator estatístico $S_{3}=1,0$; grupo 2: edificações para hotéis e residências;

- Coeficiente de arrasto, altura da edificação $H=20 \times 2,88=57,6 \mathrm{~m}$, medida dos lados em planta $\ell_{1}=25,70 \mathrm{~m}$ e $\ell_{2}=14,05 \mathrm{~m}$; consultando as figuras 4 e 5 da norma, ventos de baixa e alta turbulência respectivamente, adotaram-se valores médios: $C_{a}=1,20$ (direção $Y$, direção principal) e $\mathrm{C}_{\mathrm{a}}=1,0$ (direção $\mathrm{x}$, direção secundária), figura 1.2.

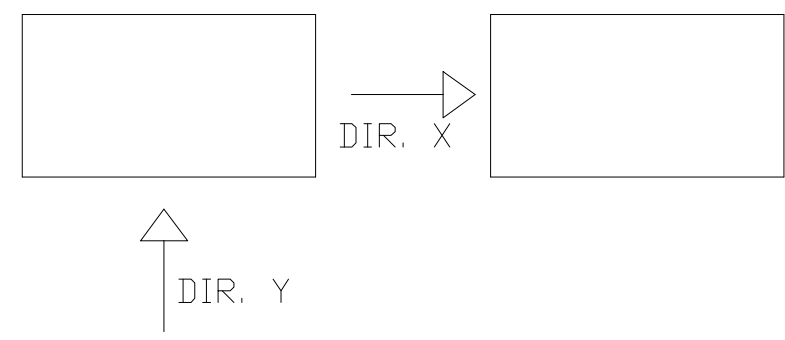

FIG. 1.2 - Direções de atuação do vento.

\subsection{SÍNTESE DOS CAPÍTULOS}

Alguns aspectos sobre as etapas de um projeto estrutural serão abordados no capítulo 2, apresentando-se comentários sobre pontos que foram considerados no desenvolvimento do trabalho, entre os quais: estruturação, pré- 
dimensionamento, parâmetros de instabilidade, sistema de contraventamento e avaliação da estrutura.

O capítulo 3 apresenta o edifício-exemplo concebido com uma estrutura convencional formada por lajes maciças, além de comentários e indicações de vantagens e desvantagens desse sistema.

Os capítulos 4 a 6 são semelhantes ao capítulo 3, considerando-se respectivamente os seguintes sistemas estruturais: estrutura convencional formada por lajes nervuradas, estrutura formada por laje lisa com viga de borda e estrutura formada por laje lisa protendida com monocordoalhas engraxadas.

O capítulo 7 apresenta um quadro comparativo entre os consumos e os custos de todas as estruturas analisadas.

O capítulo 8 acrescenta à analise o consumo e os custos das fundações.

E por fim o capítulo 9 apresenta as conclusões do trabalho. 


\section{ETAPAS DO PROJETO ESTRUTURAL}

\subsection{CONCEPÇÃO DA ESTRUTURA}

"O problema tem como característica fundamental a complexidade, por causa do número de variáveis presentes e da multiplicidade de soluções possíveis" (CORRÊA, 1991).

De posse do projeto arquitetônico, em geral se faz um estudo de soluções estruturais, que serão analisadas por uma equipe multidisciplinar. $O$ arquiteto apresentará restrições para manter a funcionalidade e a estética do seu projeto, o engenheiro de instalações posicionará as tubulações, o construtor indicará os recursos técnicos disponíveis para a construção e o incorporador estabelecerá a viabilidade financeira do investimento. Esses diversos fatores irão balizar o engenheiro de estruturas, na elaboração do projeto estrutural definitivo. Essa fase, de suma importância, surgiu recentemente com a introdução dos conceitos de qualidade total e se chama compatibilização de projetos.

Segundo ABECE (1998), "algumas reuniões entre o arquiteto e o engenheiro calculista trazem benefícios imensos, pois é através dessa interação que algumas dificuldades, normalmente encontradas entre a arquitetura e a estrutura, podem ser rapidamente solucionadas, gerando economia e ótimos resultados para toda a construção."

É importante lembrar que a estruturação segue alguns critérios. Geralmente se inicia pela locação dos pilares no pavimento-tipo, que segue a seguinte ordem: pilares de canto, pilares nas áreas comuns a todos os pavimentos (região da escada e dos elevadores), pilares de extremidade (situados no contorno do pavimento) e finalmente pilares internos.

Ao fazer a locação de pilares, o projetista já deve preocupar-se paralelamente com o posicionamento da caixa-d'água, com a formação de pórticos para suportar os esforços do vento e com a possibilidade de superposição das 
fundações. Além de tudo isso, deve-se verificar se os pilares não estão interferindo na arquitetura dos outros pavimentos (garagem, pilotis, mezanino etc), por exemplo, se permitem a realização de manobras e estacionamento dos carros ou se não afetam as áreas sociais.

A colocação das vigas vai depender do tipo de laje que será adotada, já que as vigas delimitam o contorno das lajes. Devem-se colocar as vigas no alinhamento das alvenarias e começar definindo as vigas externas do pavimento. Além daquelas que ligam os pilares que constituem os pórticos, outras vigas podem ser necessárias, para dividir um painel de laje com grandes dimensões.

Com o posicionamento das vigas as lajes ficam praticamente definidas, faltando apenas, caso existam, as lajes em balanço.

\subsection{CARREGAMENTO DA ESTRUTURA}

Depois da estrutura concebida, colocam-se as ações verticais atuantes nos pavimentos, conforme exposto no capítulo 1.

\subsection{PRÉ-DIMENSIONAMENTO}

Depois da estrutura carregada, passa-se ao pré-dimensionamento dos elementos estruturais principais: lajes, vigas e pilares. Vale salientar que, nessa fase, normalmente se considera a estrutura submetida apenas ao carregamento vertical.

\subsubsection{Lajes}

Deve-se calculá-las de início, já que elas só serão dimensionadas para os carregamentos conhecidos (cargas verticais).

\subsubsection{Vigas}

Procura-se deixar uma certa folga, principalmente naquelas vigas onde se sabe que vão absorver maiores esforços do vento. É importante lembrar que a situação ideal de projeto é o domínio 3. 


\subsubsection{Pilares}

Ao se fazer o pré-dimensionamento dos pilares, também se deve deixar uma reserva para os esforços do vento. No edifício calculado neste trabalho, como os esforços do vento seriam bastante significativos, a porcentagem máxima admitida para armadura fora da região de traspasse foi de 2,3\%.

\subsection{VERIFICAÇÃO DOS PARÂMETROS DE INSTABILIDADE}

Com o pré-dimensionamento concluído, processa-se o pórtico espacial e calculam-se os parâmetros "gama" e "alfa"; se os valores não forem aceitáveis, volta-se para a fase de concepção ou de pré-dimensionamento e aumenta-se a rigidez do edifício. Para aumentar a rigidez pode-se rever a posição dos pilares ou aumentar as dimensões das vigas e dos pilares que formam os pórticos; caso não seja suficiente podem-se inserir núcleos rígidos ou pilaresparede.

Segundo PRADO (1995), a simples inclusão de núcleos rígidos ou pilares-parede como a solução mais rápida não deve ser feita antes do estudo das demais alternativas, por eles terem um grande consumo de concreto e de aço, além da dificuldade de execução.

Se os valores dos parâmetros estiverem satisfatórios, faz-se a envoltória de esforços (verticais e horizontais) para vigas e pilares e passa-se para a próxima fase.

É importante lembrar que os parâmetros de instabilidade têm de ser verificados nas duas direções, isso porque a direção secundária muitas vezes, devido à falta de pórticos, apresenta resultados piores que os da direção principal.

Estruturas de contraventamento

As peças que suportam os esforços horizontais são ditas de contraventamento, sendo responsáveis principalmente por receber os esforços do vento. Em geral exercem esse papel: pilares, pilares-parede e pórticos.

Pórticos são conjuntos formados por vigas e pilares, conectados de modo a permitir a interação de forças e momentos (CORRÊA, 1991). Aparecem em todos os sistemas estruturais apresentados no desenvolvimento deste trabalho. Nos sistemas estruturais que apresentam lajes apoiadas diretamente sobre os 
pilares, esses pilares irão contribuir isoladamente na estrutura de contraventamento, já que a contribuição da laje não justifica o incremento no modelo.

A estrutura de contraventamento será analisada como um pórtico espacial por técnica discreta, as lajes serão consideradas como diafragmas rígidos e a rigidez de torção de vigas e pilares será desprezada, estando de acordo com a revisão da NB-1 (1997). "A laje de um pavimento poderá ser considerada como uma chapa totalmente rígida em seu plano, desde que não apresente grandes aberturas e cujo lado maior do retângulo circunscrito ao pavimento em planta não supere em três vezes o lado menor. A rigidez de torção de vigas e pilares em geral pode ser desprezada ao se analisar a estrutura de contraventamento submetida a ações horizontais."

O fato de a laje ser considerada como chapa rígida permite que ela, ao receber os esforços do vento provenientes das paredes, que são elementos perpendiculares à atuação do vento, distribua as ações de acordo com a rigidez de cada pórtico.

A verificação da estabilidade global do edifício é feita através da análise de sua estrutura de contraventamento. Na prática usual concebem-se estruturas que não precisem de considerações dos esforços de segunda ordem. Para isso a estrutura deve ser classificada como estrutura de nós fixos. Segundo a revisão da NB-1 (1997), "as estruturas onde os deslocamentos horizontais dos nós são pequenos, e, por decorrência, os efeitos globais de $2^{\mathrm{a}}$. ordem são desprezíveis (inferiores a $10 \%$ dos respectivos esforços de $1^{\text {a }}$. ordem), são chamadas estruturas de nós fixos. Nessas estruturas basta considerar os efeitos locais de $2^{a}$. ordem."

Dois processos são permitidos para classificar a estrutura como de nós fixos: o parâmetro de instabilidade $\alpha$ e o coeficiente $\gamma_{z}$. O parâmetro de instabilidade $\alpha$ classifica uma estrutura como de nós fixos se:

$$
\begin{aligned}
& \alpha=H_{\text {tot }} \sqrt{N_{k} / E_{c} I_{c}} \leq \alpha_{1} \\
& \alpha_{1}=0,2+0,1 \cdot n \Rightarrow n \leq 3 \\
& \alpha_{1}=0,6 \Rightarrow n \geq 4
\end{aligned}
$$


n : número de andares;

$\mathrm{H}_{\text {tot }}$ : altura total da estrutura;

$\mathrm{N}_{\mathrm{k}}$ : somatório de todas as forças verticais;

$\mathrm{E}_{\mathrm{C}} \mathrm{I}_{\mathrm{c}}$ : rigidez equivalente.

O coeficiente $\gamma_{z}$ classifica uma estrutura como de nós fixos se:

$$
\gamma_{\mathrm{z}}=\frac{1}{1-\frac{\Delta \mathrm{M}_{\mathrm{tot}, \mathrm{d}}}{\mathrm{M}_{1, \mathrm{tot}, \mathrm{d}}}} \leq 1,1
$$

$\Delta \mathrm{M}_{\mathrm{tot}, \mathrm{d}}$ : soma dos produtos de todas as forças verticais atuantes na estrutura, com seus valores de cálculo, pelos deslocamentos horizontais dos respectivos pontos de aplicação, obtidos da análise de $1^{\mathrm{a}}$. ordem;

$\mathrm{M}_{1, \mathrm{tot}, \mathrm{d}}$ : momento de tombamento, ou seja, a soma dos momentos de todas as forças horizontais, com seus valores de cálculo, em relação à base da estrutura.

VASCONCELOS (1987) propõe que o valor limite para $\alpha$ seja calculado pela expressão:

$$
\alpha_{\lim }=\frac{1}{\sqrt{1,2}} \cdot\left(0,88-0,44 \cdot 10^{-0,144 n}\right)
$$

O valor de $\alpha_{\text {lim }}$ calculado por essa expressão converge para 0,8 quando $n \geq 13$, que coincide com os resultados apresentados em vários edifícios projetados pelo escritório Dácio Carvalho Projetos Estruturais S/C Ltda, que, por diversas vezes, quando o edifício apresentava o valor de $\gamma_{z}$ próximo a 1,1, o valor de $\alpha$ se encontrava próximo de 0,8 . Esta prática já vem sendo aceita em vários escritórios, aparecendo mesmo como recomendação nos cadernos de critérios de projeto da construtora ENCOL.

Durante vários anos, muitos projetistas usaram a relação flechaaltura para aferir a estabilidade global das estruturas. De acordo com as conclusões apresentadas por CARMO (1995), essa relação é o valor máximo para que não seja afetado o funcionamento dos elementos estruturais, não podendo ser 
utilizada como parâmetro de instabilidade já que não apresenta nenhuma relação com eles.

Entretanto, segundo o ACl 435.3R-68 (1984), diversos projetistas e pesquisadores, o valor limite para a relação flecha-altura $(a / H) 1 / 500$ é satisfatório.

\subsection{DETALHAMENTO DO PROJETO}

Com as envoltórias obtidas do item 2.4, serão detalhadas as vigas e os pilares. Pode-se nesta fase encontrar alguma dimensão de viga ou de pilar que não satisfaça o esforço solicitante; volta-se neste caso para o item 2.3 e continuase a rotina de cálculo.

\subsection{VERIFICAÇÃO DOS CONSUMOS}

Para se fazer uma avaliação da estrutura, serão calculados os seus quantitativos (volume de concreto, massa de aço e área de forma) e os índices: espessura média, taxa de aço, taxa de aço II e taxa de forma.

\subsubsection{Espessura média}

É a relação entre o consumo total de concreto e a área estrutural (somatório das áreas das plantas de forma) do edifício.

$$
\text { Espessura média }=\frac{V\left(m^{3}\right)}{A\left(m^{2}\right)}
$$

$\mathrm{A}=20 \times 254 \mathrm{~m}^{2}$ (área estrutural do edifício-exemplo).

\subsubsection{Taxa de aço}

É a relação entre o consumo total de aço e o consumo total de concreto.

$$
\text { Taxa de aço }=\frac{P(k g)}{V\left(m^{3}\right)}
$$




\subsubsection{Taxa de aço II}

É a relação entre o consumo total de aço e a área estrutural do edifício.

$$
\text { Taxa de aço } I I=\frac{P(k g)}{A\left(m^{2}\right)}
$$

\subsubsection{Taxa de forma}

É a relação entre o consumo total de forma e a área estrutural do edifício.

$$
\text { Taxa de forma }=\frac{F\left(m^{2}\right)}{A\left(m^{2}\right)}
$$

\subsection{RECOMENDAÇÕES PARA ESTRUTURAÇÃO}

Como já foi dito na Introdução, a padronização das formas é perseguida pelos projetistas de estrutura. Alguns critérios têm sido adotados por grande parte dos projetistas e algumas construtoras têm elaborado normas internas, no que diz respeito às dimensões das peças. Obviamente essas diretrizes são apenas indicações, não devendo ser seguidas obrigatoriamente em todos os casos.

\subsubsection{Lajes}

Um bom número seria no máximo duas espessuras diferentes por pavimento; em alguns casos seriam aceitas três espessuras diferentes, não se levando em consideração as lajes em balanço.

A construtora ENCOL adota como gabarito para espessuras de lajes por pavimento:

\begin{tabular}{|lc|}
\hline \multicolumn{2}{|c|}{$\mathrm{N}^{\circ}$ de espessuras por pavimento } \\
\hline 1 & ótimo \\
\hline 2 & bom \\
\hline$>2$ & desaconselhado \\
\hline
\end{tabular}


Ainda recomenda a construtora ENCOL que as lajes não sejam rebaixadas, exceto em caso excepcional de detalhe arquitetônico.

\subsubsection{Vigas}

A altura ideal é $60 \mathrm{~cm}$, isso porque resiste a esforços consideráveis e também não causa nenhum transtorno à arquitetura; procura-se manter todas as vigas externas com a mesma altura. Para algumas vigas internas (vigas que recebem escadas ou poço de elevador, por exemplo) pode-se adotar altura de $40 \mathrm{~cm}$ ou $50 \mathrm{~cm}$. De acordo com a revisão da NB-1 (1997), a largura mínima para as vigas é $12 \mathrm{~cm}$, e em casos especiais de concretagem admitem-se $10 \mathrm{~cm}$. Se necessário, aumenta-se a largura da viga em múltiplos de $5(15 \mathrm{~cm}, 20 \mathrm{~cm}$ etc) ou em função da largura dos tijolos ou blocos utilizados.

A construtora ENCOL recomenda que as dimensões das vigas devem ser uniformizadas por pavimento, segundo o gabarito:

\begin{tabular}{|lc|}
\hline & $N^{0}$ de seções por pavimento \\
\hline 2 & ótimo \\
\hline 3 & bom \\
\hline$>3$ & desaconselhado \\
\hline
\end{tabular}

\subsubsection{Pilares}

Variações nas dimensões do pilar nos diversos pavimentos, além de dificultar a forma, às vezes aumenta o consumo de aço. Por isso adotam-se em média variações de pilar a cada dez pavimentos. É usual também fazer uma variação no nível do primeiro pavimento-tipo, isso porque os pilares na base recebem solicitações maiores e os pés-direitos do subsolo, pilotis e mezanino geralmente são maiores.

Procura-se fazer um agrupamento dos pilares com ações semelhantes, evitando número exagerado de seções. Considera-se que cinco seções por pavimento tipo é um número razoável. Quando possível, deve-se manter, nos pavimentos-tipo, a menor dimensão do pilar com $20 \mathrm{~cm}$, para não se sobressair muito da arquitetura. 
De acordo com a revisão da NB-1 (1997), "a seção transversal do pilar não deve apresentar dimensão menor que $20 \mathrm{~cm}$. Em casos especiais, permite-se a consideração de dimensões entre $20 \mathrm{~cm}$ e $12 \mathrm{~cm}$, desde que se multipliquem as ações a ser consideradas no dimensionamento por um coeficiente majorador $\gamma_{n}$, de acordo com a expressão:

$\gamma_{n}=1,75-0,75 \frac{b}{20}$

b: menor dimensão da seção transversal do pilar.

A Construtora ENCOL recomenda ainda que se utilizem pilares com seções retangulares ou quadradas, evitando-se a utilização de seções $L, U$ ou $T$, que têm uma forma de difícil execução.

\subsection{QUALIDADE DA SOLUÇÃO ADOTADA}

Diversas construtoras criaram critérios para aferir a qualidade do projeto estrutural. LARANJEIRAS (1995) elaborou, para a Construtora Suarez, normas internas sobre condições a serem observadas na execução de projetos de estruturas de concreto armado de edifícios. Um dos itens dessa norma interna é sobre a qualidade da solução adotada, que será apresentado a seguir:

"A solução estrutural adotada deve atender às exigências de qualidade impostas pelas seguintes condições:
a) segurança e durabilidade;
b) arquitetônicas;
c) funcionais;
d) construtivas;
e) estruturais;
f) integração com os demais projetos;
g) econômicas. 
As condições de segurança e durabilidade referem-se à necessidade da estrutura de:

- resistir a todas as ações e outras influências ambientais passíveis de acontecer durante as fases de construção e de utilização;

- comportar-se adequadamente sob as condições previstas de uso, durante determinado tempo de sua existência.

A segurança e a durabilidade dependem ambas da qualidade dos detalhes da armadura (emendas, dobramentos, ancoragens, ligações entre elementos, furos, etc.), com vistas a evitar rupturas localizadas e a favorecer boas condições de adensamento do concreto.

As condições arquitetônicas impostas ao projeto estrutural são, obviamente, as constantes do projeto arquitetônico.

As condições funcionais referem-se às finalidades e ao uso previsto para a estrutura, e implicam a compatibilização das ações a adotar; dos vãos; da rigidez ou da deformabilidade das peças; da estanqueidade, etc.

As condições construtivas implicam a compatibilização do projeto estrutural com os métodos, procedimentos e etapas construtivas previstas.

As condições estruturais referem-se basicamente à adequação das soluções estruturais adotadas, caracterizada pela escolha apropriada das características dos materiais; do sistema estrutural para resistir às ações verticais e às ações horizontais; do tipo de fundação; da estrutura de laje com ou sem vigas, nervuradas, pré-fabricadas; dos apoios, articulações, ligações entre os elementos estruturais, etc.

As condições de integração com os demais projetos elétrico, hidráulico-sanitário, ar condicionado, etc, referem-se à necessidade de prever rebaixos, furos, shafts ou dispor as peças estruturais de modo a viabilizar e compatibilizar a coexistência da estrutura com os demais sistemas.

As condições econômicas referem-se à necessidade de otimizar os custos de investimento (construção), associados ao de manutenção da estrutura em uso, e de compatibilizar esses custos com os prazos desejados." 


\subsection{SOBRE O SOFTWARE TQS}

O software permite que os dados de entrada, relativos à geometria $\mathrm{e}$ ao carregamento do pavimento, sejam fornecidos graficamente. Com esses dados já se pode fazer uma distribuição de ações das lajes para as vigas e dessas para os pilares.

No nível do pavimento têm-se opções de várias análises: viga contínua, discretização através de elementos de barra e de placa. É importante salientar que a modelagem da estrutura é de inteira responsabilidade do engenheiro, já que o software não tem discernimento de qual é o melhor modelo matemático para representar o modelo físico.

Um arquivo-texto contendo informações sobre as características do vento (velocidade básica, fatores e coeficiente de arrasto) e do pórtico espacial é editado pelo usuário. Esse arquivo é processado anteriormente ao processamento do pórtico que fornece: parâmetros de instabilidade $\left(\alpha\right.$ e $\left.\gamma_{z}\right)$ e esforços em vigas e pilares. Caso os parâmetros estejam satisfatórios, transferem-se os esforços para vigas e pilares, caso contrário volta-se para a entrada de dados para efetuar as alterações desejadas.

Passa-se então ao detalhamento da estrutura, onde são emitidos relatórios de cálculo e desenhos, que podem ser editados graficamente ou refeitos se necessários.

É importante salientar que em todas as fases existe um arquivo de critérios onde o projetista vai impor a modelagem para o cálculo, de acordo com sua vontade, tendo assim um pleno controle sobre o processamento e o detalhamento.

Modelos adotados para as alternativas

Todas as análises serão feitas considerando o comportamento elástico-linear do pavimento.

Os pavimentos das estruturas convencionais (laje-viga-pilar) serão analisados por grelha só de vigas, com as lajes isoladas, e os pavimentos com lajes lisas, todo o pavimento será discretizado por grelha, ou seja, a laje será incorporada ao modelo. 
Nos apoios foram considerados trechos rígidos com um único nó no centro de apoio e foram adicionados elementos tipo mola para simulação das características de deformabilidade do apoio. A constante de mola usada foi uma indicação prática $2 \mathrm{El} / \ell$, que é um valor menor que a pior situação na fase construtiva $3 \mathrm{El} / \ell$. Considerou-se que o trecho rígido tem como características geométricas a largura do pilar e a distância entre os pavimentos.

Segundo CORRÊA (1991), "observa-se que a adoção desses trechos rígidos está de acordo com a hipótese da manutenção da seção plana do pilar e incorpora a consideração de excentricidades na aplicação de forças no pilar. No ponto de apoio, que deve ser um nó no modelo, são aplicadas as condições de contorno ou a ligação a elementos do tipo mola para a simulação de apoio flexível."

De acordo com CORRÊA (1991), outra aplicação interessante consiste em desprezar o efeito da torção em vigas de concreto armado em que tal efeito não é fundamental para o equilíbrio da estrutura. Ainda afirma que a consideração de $1 \%$ do momento de inércia a torção produz resultados satisfatórios. Esse valor deve ser alterado para 10\% quando houver trechos curtos. 


\section{ESTRUTURA CONVENCIONAL COM LAJES MACIÇAS}

Entende-se como estrutura convencional aquela em que as lajes se apoiam em vigas (tipo laje-viga-pilar). A laje maciça não pode vencer grandes vãos, devido ao seu peso próprio. É pratica usual adotar-se como vão médio econômico das lajes um valor entre $3,5 \mathrm{~m}$ e $5 \mathrm{~m}$. Esses limites foram respeitados sempre que possível na estruturação indicada na figura 3.1.

Nas lajes maciças devem ser respeitados os seguintes limites mínimos para a espessura:

a) $5 \mathrm{~cm}$ para lajes de cobertura;

b) $7 \mathrm{~cm}$ para lajes de piso;

c) $10 \mathrm{~cm}$ para lajes que suportem veículos de peso total menor ou igual a $30 \mathrm{kN}$;

d) $12 \mathrm{~cm}$ para lajes que suportem veículos de peso total maior que $30 \mathrm{kN}$.

Algumas desvantagens desse sistema são:

- devido aos limites impostos, apresenta uma grande quantidade de vigas, fato esse que deixa a forma do pavimento muito recortada, diminuindo a produtividade da construção;

- os recortes diminuem o reaproveitamento das formas;

- apresenta grande consumo de concreto, aço e formas.

E as principais vantagens são:

- a existência de muitas vigas, por outro lado, forma muitos pórticos, que garantem uma boa rigidez à estrutura de contraventamento;

- há uma grande contribuição das mesas na deformação das vigas; 


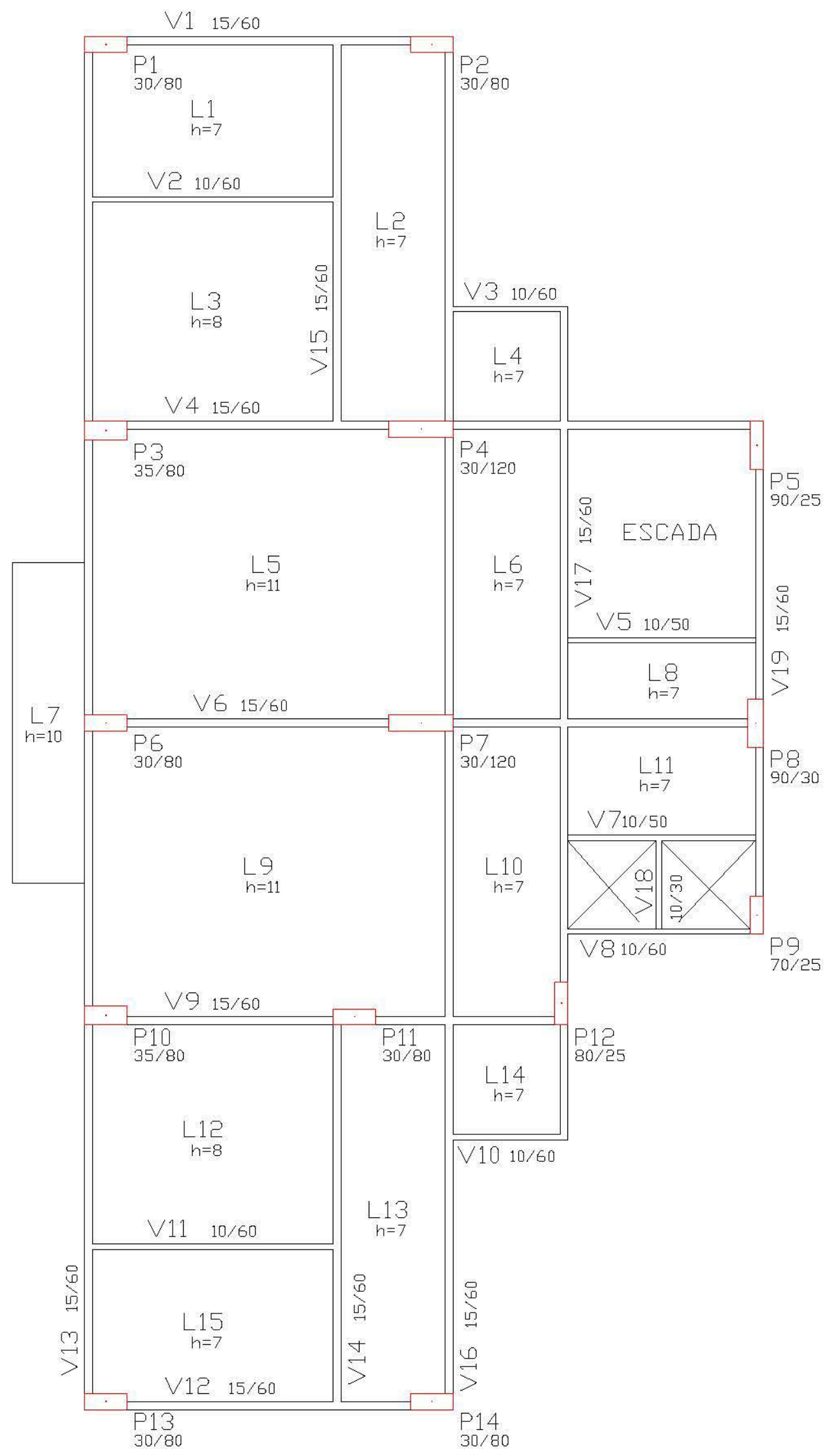

FIG. 3.1 - Forma da estrutura convencional com lajes maciças. 
- foi durante anos o sistema estrutural mais utilizado nas construções de concreto, por isso a mão-de-obra já é bastante treinada.

A resistência do concreto nessa alternativa será $f_{c k}=35 \mathrm{MPa}$ (vigas e pilares) e $\mathrm{f}_{\mathrm{ck}}=20 \mathrm{MPa}$ (lajes).

Os resultados relativos à estrutura com lajes maciças estão indicados nas tabelas $3.1,3.2$ e 3.3 .

TABELA 3.1 - Consumos de materiais.

\begin{tabular}{|c|c|c|c|}
\cline { 2 - 4 } \multicolumn{1}{c|}{} & $\begin{array}{c}\text { VOL. CONCRETO } \\
\left(\mathrm{m}^{3}\right)\end{array}$ & $\begin{array}{c}\text { AÇO } \\
(\mathrm{kg})\end{array}$ & $\begin{array}{c}\text { ÁREA DE FORMA } \\
\left(\mathrm{m}^{2}\right)\end{array}$ \\
\hline LAJES & 366,0 & 18.389 & $4.234,6$ \\
\hline VIGAS & 244,6 & 36.888 & $3.535,0$ \\
\hline PILARES & 206,8 & 21.277 & $1.872,0$ \\
\hline TOTAL & 817,4 & 76.554 & $9.641,6$ \\
\hline
\end{tabular}

TABELA 3.2 - Índices.

\begin{tabular}{|c|c|c|c|}
\hline $\begin{array}{c}\text { ESP. MÉDIA } \\
(\mathrm{cm})\end{array}$ & $\begin{array}{c}\text { Tx. DE AÇO } \\
\left(\mathrm{kg} / \mathrm{m}^{3}\right)\end{array}$ & $\begin{array}{c}\text { Tx. DE AÇO II } \\
\left(\mathrm{kg} / \mathrm{m}^{2}\right)\end{array}$ & $\begin{array}{c}\text { Tx . FORMA } \\
\left(\mathrm{m}^{2} / \mathrm{m}^{2}\right)\end{array}$ \\
\hline 16,09 & 93,66 & 15,07 & 1,90 \\
\hline
\end{tabular}

TABELA 3.3 - Deslocamentos e parâmetros de instabilidade.

\begin{tabular}{|c|c|c|}
\cline { 2 - 3 } \multicolumn{1}{c|}{} & Direção $Y$ & Direção $X$ \\
\hline Deslocamento $(\mathrm{cm})$ & 5,60 & 2,82 \\
\hline$\gamma_{z}$ & 1,06 & 1,07 \\
\hline$\alpha$ & 0,57 & 0,64 \\
\hline
\end{tabular}




\section{ESTRUTURA CONVENCIONAL COM LAJES NERVURADAS}

\subsection{LAJES NERVURADAS}

As lajes nervuradas são por definição um conjunto de nervuras solidarizadas por uma mesa de concreto (figura 4.1). $O$ fato de as armaduras serem responsáveis pelos esforços resistentes de tração permite que a zona tracionada seja discretizada em forma de nervuras, não comprometendo a zona comprimida, que será resistida pela mesa de concreto. Segundo a revisão da NB-1 (1997), "são as lajes moldadas no local ou com nervuras pré-moldadas, cuja zona de tração é constituída por nervuras entre as quais pode ser colocado material inerte."

A vantagem principal desta utilização é a redução do peso próprio da estrutura, já que o volume de concreto diminui, e ainda há um aumento na inércia, já que a laje tem sua altura aumentada.

Para a execução destas nervuras pode-se utilizar material inerte como forma perdida ou pode-se utilizar forma reaproveitável, na forma de caixotes. Tijolo cerâmico, bloco de cimento e bloco de EPS (isopor) são os mais utilizados como materiais inertes e os caixotes na sua maioria são feitos de propileno ou de metal.
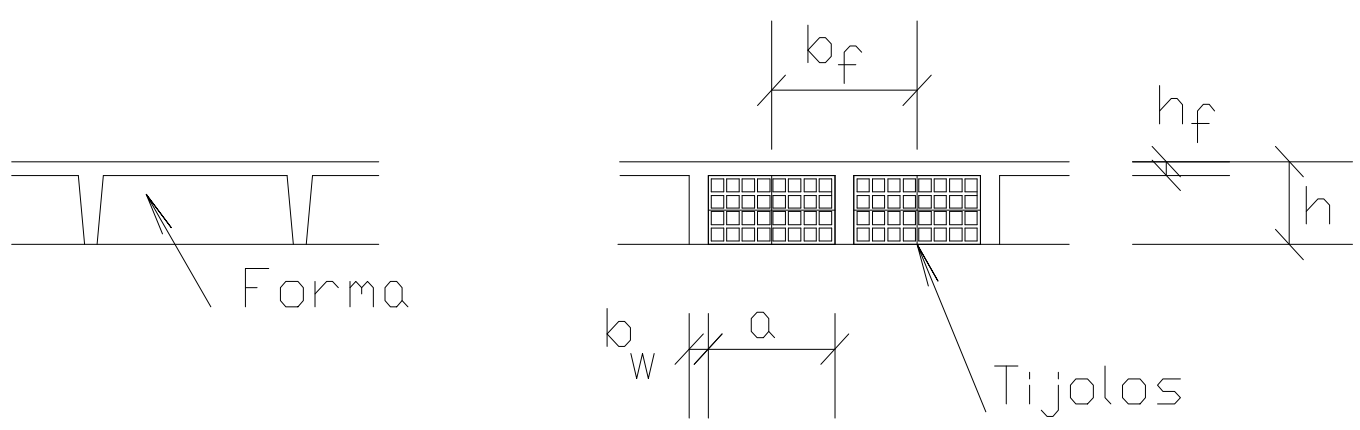

FIG. 4.1 - Seções transversais de lajes nervuradas. 
Segundo BOCCHI (1995), a prática usual consiste em fazer painéis com vãos maiores que os das lajes maciças, apoiados em vigas mais rígidas que as nervuras.

\subsubsection{Prescrições}

De acordo com a norma NB-1/78, item 3.3.2.10, são válidos para as lajes nervuradas os itens 3.3.2.1, 3.3.2.3 e 3.3.2.8, desde que sejam obedecidas as prescrições do item 6.1.1.3.

a) Item 3.3.2.1 da NB-1/78: permite o cálculo como placa no regime elástico, processo simplificado.

b) Item 3.3.2.3 da NB-1/78: especifica os vãos teóricos a serem adotados.

c) Item 3.3.2.8 da NB-1/78, sobre armadura nos cantos das lajes retangulares livremente apoiadas nas quatro bordas: armaduras que irão resistir ao momento volvente.

d) Item 6.1.1.3 da NB-1/78:

- distância livre entre nervuras não deve ultrapassar $100 \mathrm{~cm}$;

- espessura da nervura não deve ser inferior a $4 \mathrm{~cm}$ e a da mesa não deve ser menor que $4 \mathrm{~cm}$ nem que $1 / 15$ da distância livre entre nervuras;

- apoio das lajes deve ser ao longo de uma nervura;

- lajes armadas numa só direção, são necessárias nervuras transversais sempre que haja cargas concentradas a distribuir ou quando o vão teórico for superior a $4 \mathrm{~m}$, exigindo-se duas nervuras no mínimo se esse vão ultrapassar $6 \mathrm{~m}$;

- em nervuras com espessura inferior a $8 \mathrm{~cm}$, não é permitido colocar armadura de compressão na face oposta à mesa.

e) Outras prescrições da NB-1/78, de acordo com ANDRADE (1977), são indicadas para se tratar a laje como placa: 
- a resistência da mesa à flexão deverá ser verificada sempre que a distância livre entre nervuras superar $50 \mathrm{~cm}$ ou houver carga concentrada no painel entre nervuras;

- as nervuras serão verificadas ao cisalhamento como vigas se a distância livre entre nervuras ultrapassar $50 \mathrm{~cm}$, como laje em caso contrário;

- nas lajes armadas em uma direção, deve-se colocar uma armadura de distribuição, na mesa de compressão, de $0,9 \mathrm{~cm}^{2} / \mathrm{m}$ ou $1 / 5$ da armadura principal;

- os estribos, quando necessários, não devem ter espaçamento maior que $20 \mathrm{~cm}$, nem diâmetro maior do que $1 / 8$ da largura das nervuras.

\subsubsection{Espessura equivalente}

$\mathrm{JI}^{1}$ apud BARBIRATO (1997) baseia-se no conceito de "espessura equivalente" para encontrar a laje maciça com rigidez correspondente à da laje nervurada. Para nervuras espaçadas igualmente nas duas direções, a laje maciça equivalente é considerada isótropa, caso contrário seria ortótropa. A equivalência é feita segundo a inércia de flexão, e é calculada pela fórmula:

$$
h_{\text {eq }}=\left(\frac{12 . l}{a_{1}}\right)^{1 / 3}
$$

$a_{1}$ : distância entre eixos de nervuras;

I: momento de inércia da seção transversal T, sem considerar a fissuração e em relação ao eixo baricêntrico horizontal.

Como a mesa solidariza as nervuras, o momento de inércia a ser calculado é o da seção "T”, cuja largura colaborante, segundo a NB-1/78, é:

$$
b_{1} \leq\left\{\begin{array}{l}
0,10 L \\
8 h_{f} \\
0,5 a
\end{array}\right.
$$

${ }^{1} \mathrm{JI}, \mathrm{X}$; CHEN, S. et al. (1985). Deflection of waffle slabs under gravity and in plane loads. In: SABNIS, G. Deflections of concrete structures. Detroit, ACI. p. 283-295 (ACI SP-66). 


$$
b_{f}=2 b_{1}+b_{w}
$$

$\mathrm{L}=\ell: \quad$ tramo simplesmente apoiado;

$\mathrm{L}=0,75 \ell$ : tramo com momento fletor apenas em uma extremidade;

$\mathrm{L}=0,60 \ell$ : tramo com momento fletor nas duas extremidades;

$\mathrm{L}=2 \ell$ : $\quad$ tramo em balanço;

$\ell$ : $\quad$ vão teórico;

L: $\quad$ distância entre os pontos de momento nulo.

\subsubsection{Processo simplificado}

Calcula-se normalmente, como se fosse uma placa, adotando-se a espessura equivalente demonstrada no item anterior. Depois de calculados os momentos e as cortantes por faixa de um metro, nas duas direções, esses valores são multiplicados pelo valor da largura colaborante $b_{f}$, verificando-se em seguida $a$ flexão e o cisalhamento, tanto nas nervuras como nas mesas.

\section{a) Flexão das nervuras}

Com os valores dos esforços de flexão por nervura verifica-se a armadura necessária, de acordo com as seguintes seções:

$\Rightarrow$ Mesa comprimida, seção resistente $b_{\mathrm{f}} \mathrm{h}$ (mesa cortada pela linha neutra);

$\Rightarrow$ Mesa tracionada, seção resistente $b_{w} h$.

Atentar também para aspectos como: ancoragens nos apoios, deslocamentos dos diagramas, armaduras mínimas e fissuração.

\section{b) Cisalhamento nas nervuras}

Se a $550 \mathrm{~cm}$, a verificação é como laje. Logo, será dispensada armadura transversal (estribos nas nervuras) sempre que: 


$$
\begin{aligned}
& \tau_{\mathrm{wd}} \leq \tau_{\mathrm{wu} 1} \\
& \tau_{\mathrm{wd}}=\frac{1,4 \mathrm{~V}_{\mathrm{k}}}{\mathrm{b}_{\mathrm{w}} \mathrm{d}}
\end{aligned}
$$

$\mathrm{V}_{\mathrm{k}}$ : Esforço cortante por nervura;

$\mathrm{d}$ : Altura útil da nervura;

$\tau_{\text {wu1 }}:$ ver item 5.3.1.2 da NB-1/78.

Se a $>50 \mathrm{~cm}$, as nervuras são verificadas como vigas; procura-se evitar essa situação. Serão armadas ao cisalhamento seguindo todas as prescrições de norma, armadura mínima de cisalhamento, inclusive, e armadura perpendicular à nervura, na mesa, por toda a sua largura útil, com seção mínima de $1,5 \mathrm{~cm}^{2} / \mathrm{m}$. Necessita-se também de $b_{w} \geq 8 \mathrm{~cm}$.

\section{c) Cálculo da mesa}

A resistência à mesa de flexão deverá ser verificada como laje apoiada nas bordas sempre que a distância livre entre nervuras superar $50 \mathrm{~cm}$ $(a>50 \mathrm{~cm})$ ou houver carga concentrada no painel entre nervuras.

A tensão de cisalhamento nas ligações mesa-nervura é verificada em casos que a $>50 \mathrm{~cm}$, não sendo necessária para casos em que $a \leq 50 \mathrm{~cm}$, com $\tau_{\text {wd }} \leq \tau_{\text {wu1 }}$ no cálculo das nervuras. A verificação é feita calculando-se a tensão de cisalhamento que ocorre na ligação mesa-nervura. $V_{d}$ é a máxima força cortante por nervura.

$$
\begin{aligned}
& \tau_{m d}=\frac{V_{d}}{z \cdot h_{f}} \frac{1}{2}\left(1-\frac{b_{w}}{b_{f}}\right) \Rightarrow \text { mesa comprimida } \\
& \tau_{m d}=\frac{V_{d}}{z \cdot h_{f}} \frac{A_{s 1}}{A_{S}} \Rightarrow \text { mesa tracionada } \\
& \tau_{w u}^{*}=\beta \cdot 0,30 \cdot f_{c d} \leq \beta \cdot 4,5(M P a) \\
& \beta=1 \text { se } a>50 \mathrm{~cm}
\end{aligned}
$$


Se $\tau_{\mathrm{md} \leq} \tau_{\mathrm{wu}}{ }^{*}$ calcula-se a armadura transversal $\mathrm{a}_{\mathrm{st}}$ (por metro) a ser colocada na mesa, perpendicularmente à nervura:

$$
\begin{aligned}
& a_{s t}=\frac{V_{d}}{z \cdot f_{y d}} \frac{1}{2}\left(1-\frac{b_{w}}{b_{f}}\right) \Rightarrow \text { mesa comprimida } \\
& a_{s t}=\frac{V_{d}}{z \cdot f_{y d}} \frac{A_{S 1}}{A_{S}} \Rightarrow \text { mesa tracionada } \\
& a_{s t} \geq 1,5 \mathrm{~cm}^{2} / \mathrm{m} .
\end{aligned}
$$

Z= distância entre a resultante de compressão e a resultante de tração;

$\mathrm{f}_{\mathrm{yd}}=$ resistência de cálculo do aço à tração;

$\tau_{\mathrm{wu}}=$ valor último de $\tau_{\mathrm{w}}$ (tensão convencional de cisalhamento de referência).

\subsubsection{Analogia de grelha}

A analogia de grelha consiste em substituir a placa por uma malha equivalente de vigas. As cargas distribuídas dividem-se em elementos de grelha equivalente, de acordo com a área de influência de cada uma. Cargas concentradas devem ser aplicadas diretamente nos nós.

Como a laje nervurada já é um conjunto de vigas, constitui assim a própria malha equivalente, atentando para o fato de as vigas possuírem seção "T", devido à mesa de concreto. As rigidezes à torção e à flexão da placa nas duas direções são tratadas como concentradas nas vigas. Devem ter valores tais que, quando a placa e o reticulado equivalente são submetidos ao mesmo carregamento, eles se deformem de modo idêntico e tenham os mesmos esforços internos, em seções correspondentes.

\subsubsection{Continuidade}

Ao se considerar continuidade entre painéis de lajes nervuradas adjacentes, ou em casos de lajes em balanço engastadas, surgem momentos fletores negativos, ou seja, tração na zona superior da nervura (região da mesa) e compressão na zona inferior da nervura. Nesse caso a seção resistente a se computar é apenas a seção retangular da nervura. 
Sendo a seção da nervura suficiente para absorver os esforços não há problema em se considerar a continuidade. Quando a seção da nervura não for suficiente alguns artifícios podem ser usados para aumentar a resistência na região de momentos negativos: aumentar a largura das nervuras, utilizar laje nervurada dupla, com mesas superior e inferior, ou região maciça de concreto.

Pode-se ainda desprezar a continuidade, aceitando a fissuração junto aos apoios. Com a finalidade de limitar as aberturas de fissuras, recomendase a adoção de armadura de caráter construtivo.

\subsection{LAJES PRÉ-MOLDADAS}

As lajes pré-fabricadas surgem como um passo decisivo na industrialização do processo da construção civil. Segundo $\mathrm{KONCZ}^{2}$ apud BORGES (1997), a pré-fabricação é um método industrial de construção no qual os elementos fabricados em série, por sistemas de produção em massa, são posteriormente montados em obra, tendo como principais vantagens a redução do tempo de construção, do peso da estrutura e, consequentemente, do custo final da obra. Pode-se ainda salientar como grande vantagem a ausência de formas para as lajes.

Vários tipos de lajes pré-moldadas são oferecidas no mercado. Destacam-se entre elas: laje alveolar, laje com vigotas e laje treliçada. Dentre essas, a que será utilizada neste trabalho é a laje treliçada, por ser indicada para edifícios de múltiplos andares que requerem, além do efeito de placa, o efeito de chapa.

\subsubsection{Lajes treliçadas}

Lajes treliçadas (figura 4.2) são lajes nervuradas compostas de elementos pré-fabricados, constituídos de treliças eletrossoldadas como armadura na formação da seção estrutural, entre as quais são utilizados blocos de material leve (LIMA, 1993). Esse material leve é não estrutural e pode ser composto por: bloco cerâmico, bloco de concreto ou bloco de EPS (poliestireno expandido). A solidarização é feita com a concretagem da capa juntamente com as nervuras. 


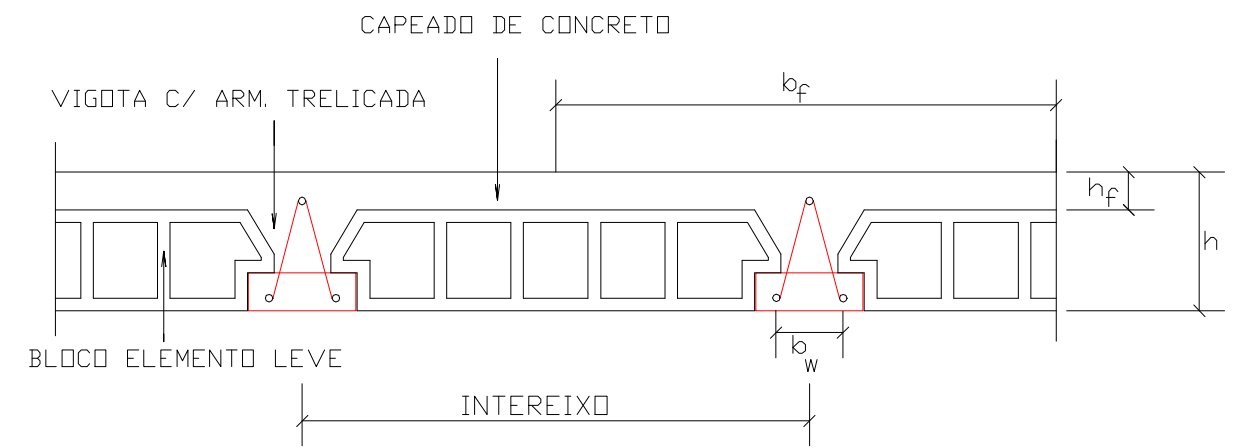

FIG. 4.2 - Seção transversal de laje treliçada.

Esse tipo de laje permite a utilização de nervuras transversais (lajes treliçadas bidirecionais), que serão muito importantes para diminuição das flechas e no travamento transversal da laje. De acordo com GASPAR (1997), a montagem de nervuras transversais aumenta o campo de aplicação dessas lajes, pois além da conhecida função de placa, consegue-se também que estas funcionem como chapas, colaborando na estabilidade global de edifícios de múltiplos andares, transferindo esforços horizontais para os painéis de contraventamento. Esse aspecto foi comentado no item 2.4. Outras vantagens são:

- fácil colocação de armaduras adicionais, possibilitando vãos maiores;

- as barras diagonais tendem a criar uma ligação contínua entre os elementos pré-fabricados e o capeamento, resultando em boa resistência a tensões de cisalhamento;

- facilidade de manuseio, devido ao baixo peso.

As lajes treliçadas têm altura (h) variando entre 10 e $30 \mathrm{~cm}$ e vãos usuais de 4 a $7 \mathrm{~m}$, podendo chegar a vãos de até $12 \mathrm{~m}$.

\subsubsection{Prescrições}

Os painéis de lajes constituídos por vigotas treliçadas podem ser calculados com base nas prescrições da NB-1/78, referentes às lajes nervuradas, apresentadas no item 4.1.1.

${ }^{2}$ KONCZ, T. (1976). Manual de la construccion prefabricada. Madrid, Hermann Blume. 
Procura-se sempre dimensionar o capeado de maneira que a linha neutra o corte, para que a seção possa ser calculada como retangular de largura igual $a b_{f}$, caso contrário tem que se fazer considerações de seção "T". Recomenda-se que o capeado $\left(h_{f}\right)$ seja igual ou superior a $4 \mathrm{~cm}$, a fim de absorver os esforços de compressão, garantir uma concretagem adequada e permitir a passagem de tubulações. Por simplicidade despreza-se a consideração de eventuais mísulas (figura 4.2) no dimensionamento.

$\mathrm{Na}$ concretagem devem-se colocar escoras no sentido transversal das treliças, porque enquanto o concreto estiver fresco a compressão será resistida pela armadura superior.

\subsection{ALTERNATIVAS ADOTADAS}

Essa solução (estrutura convencional com lajes nervuradas) vem sendo utilizada predominantemente em algumas regiões do país. É de fácil execução e pode ser lançada com grandes vãos, como se indica na figura 4.3. É comum a utilização de lajes maciças em alguns trechos, como as lajes em balanço e as lajes próximas ao elevador e escada. Serão feitas três alternativas a partir dessa concepção: uma utilizando caixotes de propileno, uma utilizando tijolos como material inerte e outra utilizando lajes pré-fabricadas. Várias vantagens são apresentadas:

- pode-se definir um pavimento com poucas lajes; devido à sua capacidade de vencer grandes vãos, no edifício-exemplo cada apartamento ficou definido praticamente em duas lajes;

- a forma possui poucas vigas, ou seja, é pouco recortada, facilitando a execução;

- o fato de ter poucas vigas faz com que a estrutura não interfira muito na arquitetura;

- o consumo da laje nervurada é muito baixo.

A resistência do concreto nessas alternativas será $f_{c k}=35 \mathrm{MPa}$ (vigas e pilares) e $\mathrm{f}_{\mathrm{ck}}=20 \mathrm{MPa}$ (lajes). 


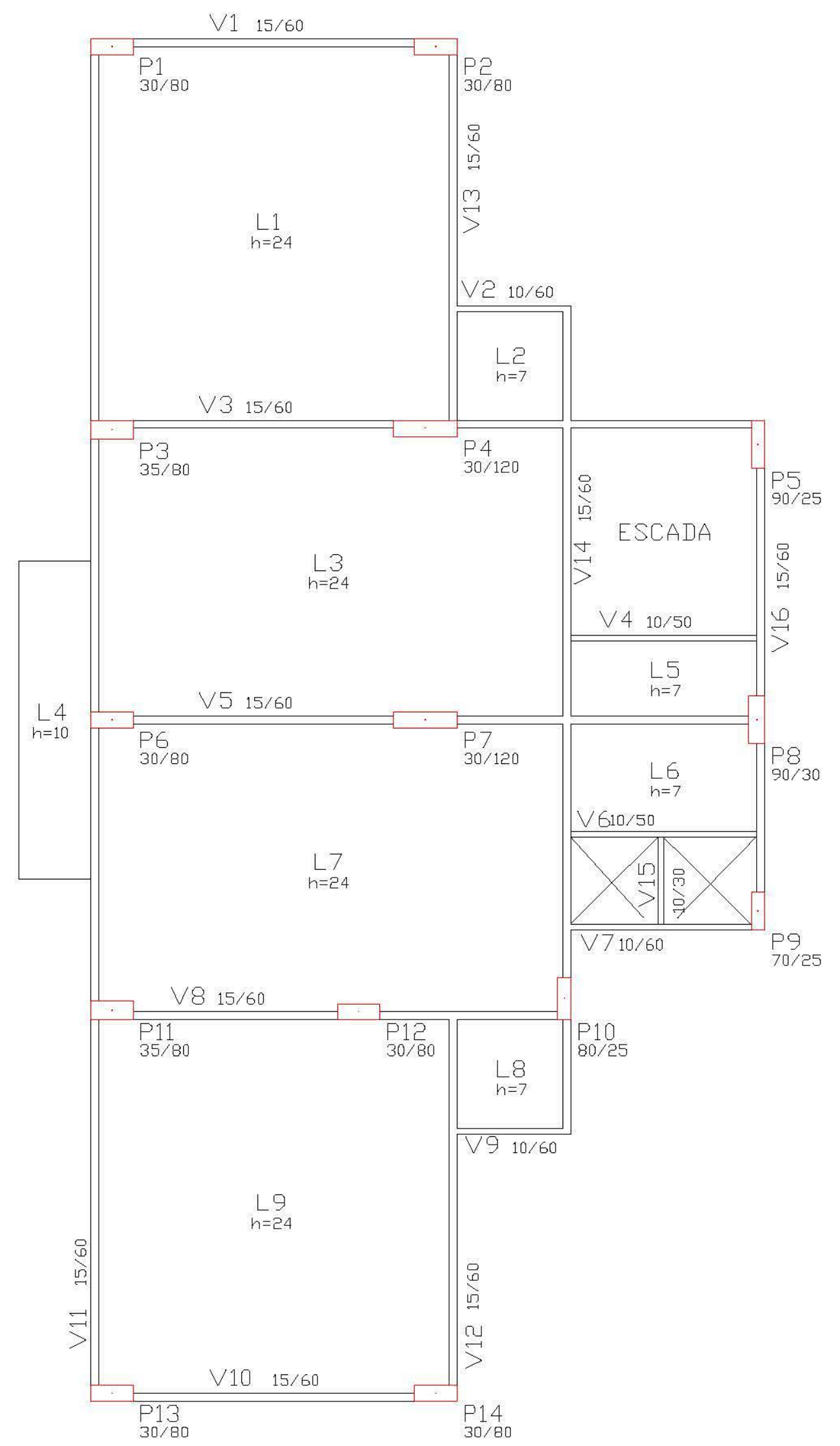

FIG. 4.3 - Forma da estrutura convencional com lajes nervuradas. 


\subsubsection{ALTERNATIVA UTILIZANDO CAIXOTES DE PROPILENO}

A utilização dos caixotes (figura 4.4) traz como vantagens: o fato desses elementos não onerarem o peso próprio da estrutura e a presença do forro falso, que permite a passagem de dutos de instalações não embutidos na estrutura.

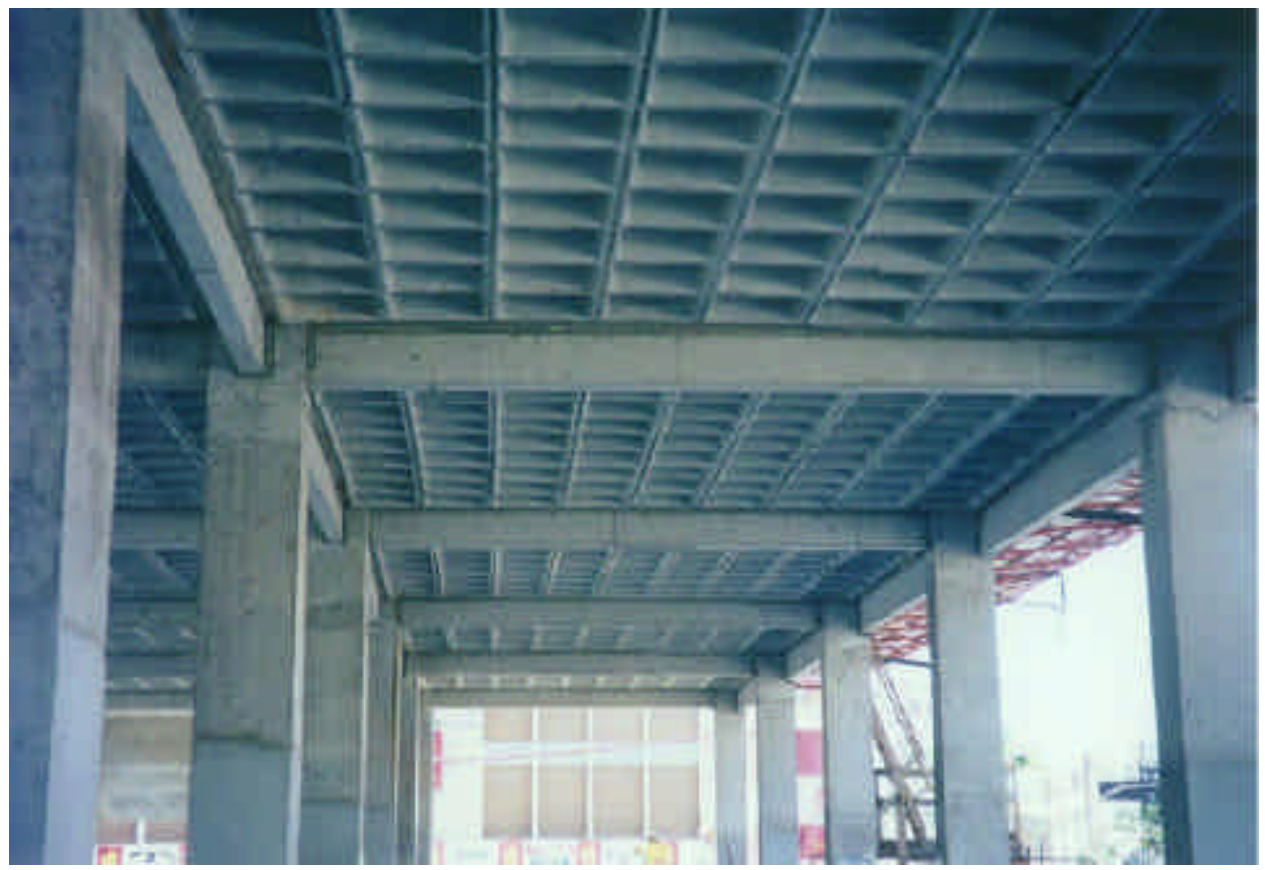

FIG. 4.4 - Laje nervurada construída com caixotes.

A laje nervurada constituída com os caixotes da figura 4.5 tem uma altura equivalente de inércia $h_{i}=13,65 \mathrm{~cm}$, e uma altura equivalente de consumo $\mathrm{h}_{\mathrm{c}}=7,47 \mathrm{~cm}$.

\section{a) Processo construtivo}

Nesse sistema, após a retirada do escoramento, injeta-se ar comprimido no furo existente no caixote de fibra e o mesmo é expulso (figura 4.6), permitindo o seu reaproveitamento. Alguns fabricantes afirmam que um caixote pode ser reutilizado até cem vezes (FORMPLAST).

Existe uma tendência de se substituir o assoalho da laje por escoras, barroteamentos e contra-barroteamentos (figura 4.7). Isso proporciona uma grande economia para os sistemas estruturais que utilizam lajes nervuradas com caixotes. 
De acordo com o fabricante FORMPLAST, essa economia é estimada em $35 \%$ da área de forma das lajes. Esse artifício não foi considerado neste trabalho, por ainda não estar regularizado junto ao ministério do trabalho, sendo proibido por alguns fiscais de segurança do trabalho.
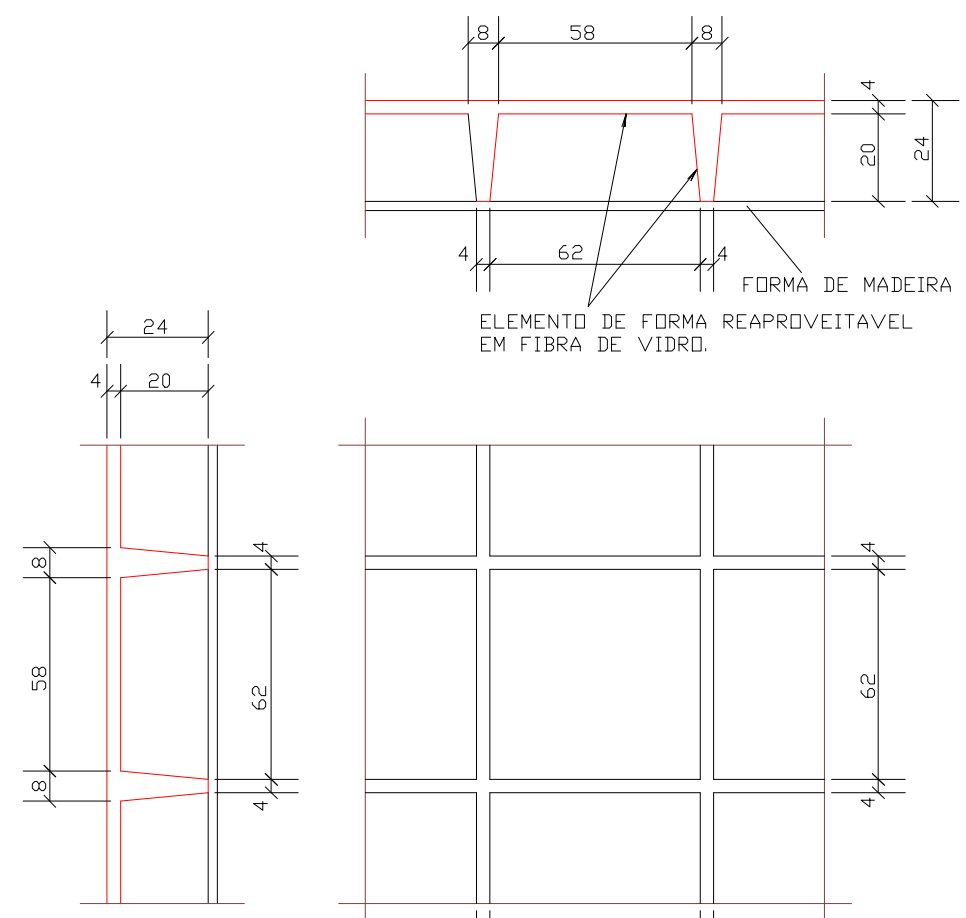

ELEMENTI DE FURMA REAPRQVEITAVEL
EM FIBRA DE VIDRD.

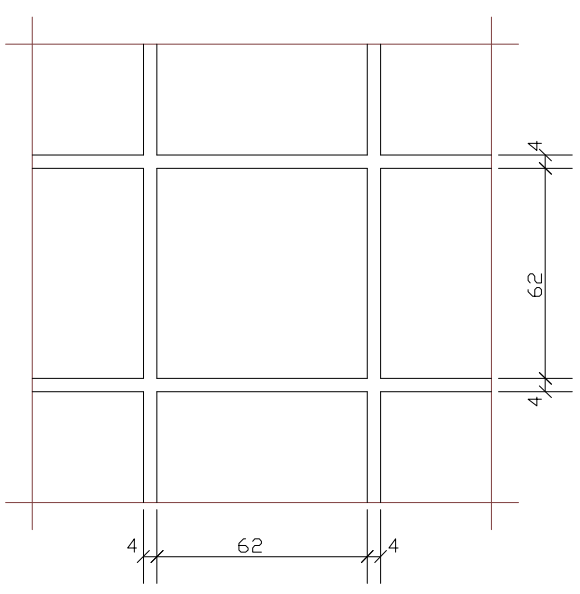

FIG. 4.5 - Corte transversal da alternativa utilizando caixotes.
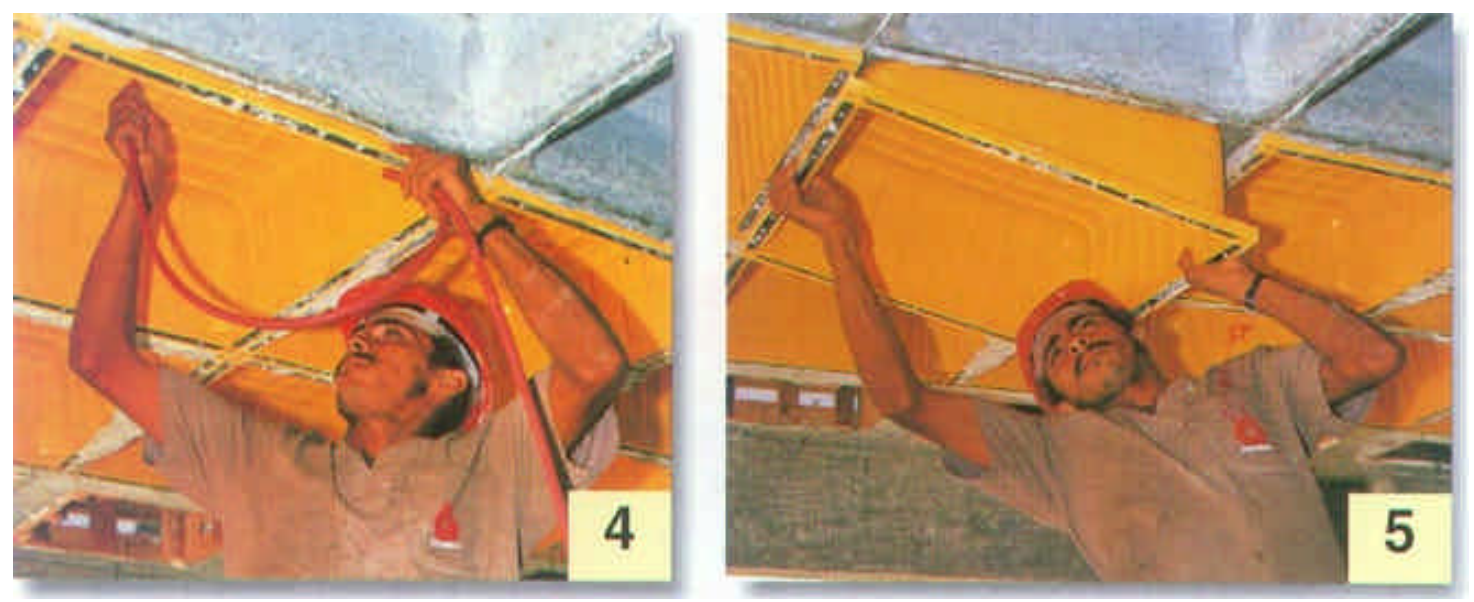

FIG. 4.6 - Retirada dos caixotes. (FORMPLAST, 1998) 


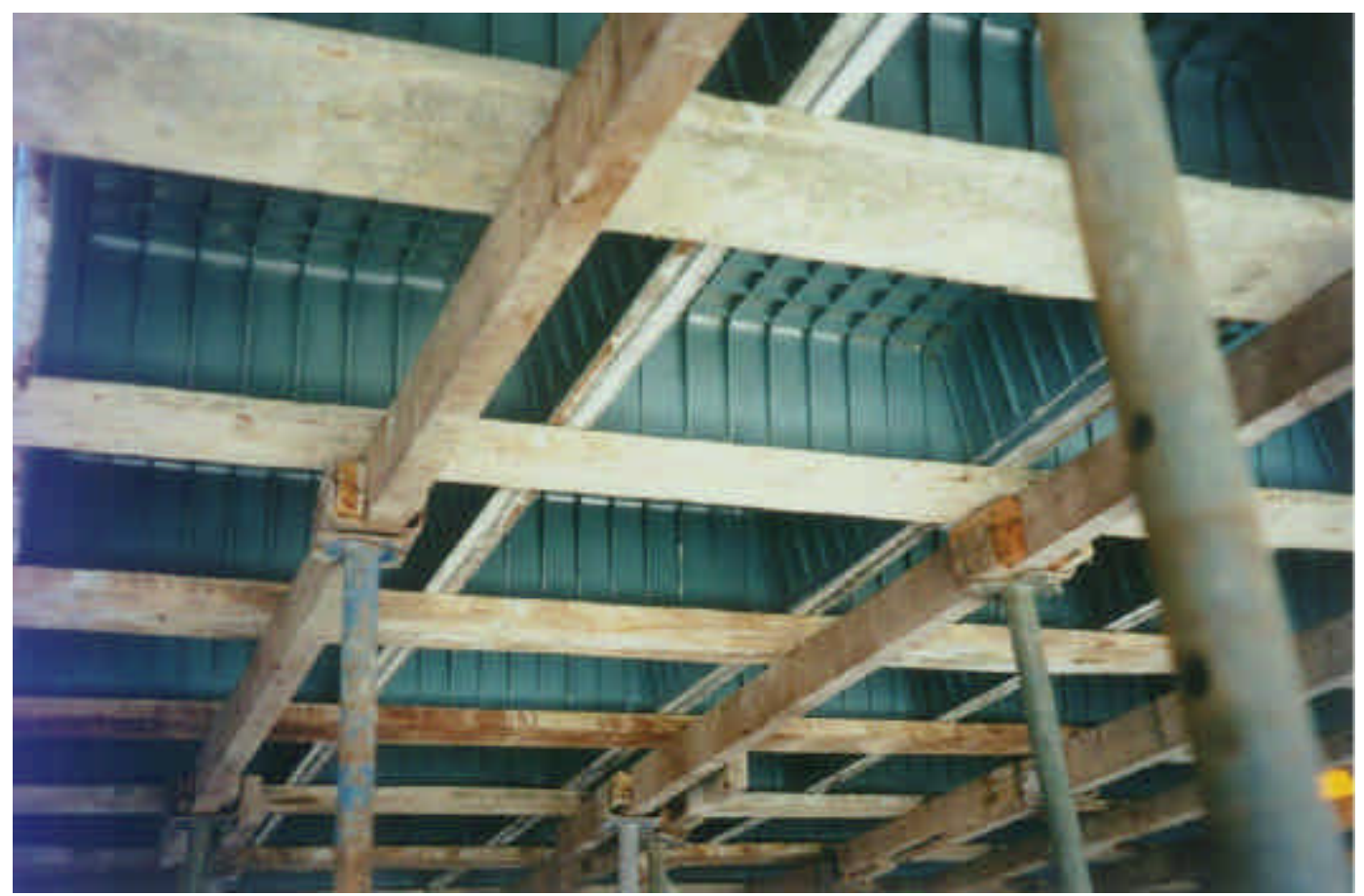

FIG. 4.7 - Escoramento dos caixotes sem assoalho.

\section{b) Resultados}

Os resultados relativos à estrutura com lajes nervuradas utilizando caixotes estão indicados nas tabelas 4.1 , 4.2, 4.3 e 4.4.

TABELA 4.1 - Consumos de materiais.

\begin{tabular}{|c|c|c|c|}
\cline { 2 - 4 } \multicolumn{1}{c|}{} & $\begin{array}{c}\text { VOL. CONCRETO } \\
\left(\mathrm{m}^{3}\right)\end{array}$ & $\begin{array}{c}\text { AÇO } \\
(\mathrm{kg})\end{array}$ & $\begin{array}{c}\text { ÁREA DE FORMA } \\
\left(\mathrm{m}^{2}\right)\end{array}$ \\
\hline LAJES & 326,6 & 14.704 & $4.327,4$ \\
\hline VIGAS & 190,8 & 30.253 & $2.773,8$ \\
\hline PILARES & 206,8 & 19.384 & $1.872,0$ \\
\hline TOTAL & 724,2 & 64.341 & $8.973,2$ \\
\hline
\end{tabular}

TABELA 4.2 - Índices.

\begin{tabular}{|c|c|c|c|}
\hline $\begin{array}{c}\text { ESP. MÉDIA } \\
(\mathrm{cm})\end{array}$ & $\begin{array}{c}\text { TAXA DE AÇO } \\
\left(\mathrm{kg} / \mathrm{m}^{3}\right)\end{array}$ & $\begin{array}{c}\text { TX. DE AÇO II } \\
\left(\mathrm{kg} / \mathrm{m}^{2}\right)\end{array}$ & $\begin{array}{c}\text { TX. FORMA } \\
\left(\mathrm{m}^{2} / \mathrm{m}^{2}\right)\end{array}$ \\
\hline 14,25 & 88,84 & 12,67 & 1,77 \\
\hline
\end{tabular}


TABELA 4.3 - Deslocamentos e parâmetros de instabilidade.

\begin{tabular}{|c|c|c|}
\cline { 2 - 3 } \multicolumn{1}{c|}{} & Direção $Y$ & Direção $X$ \\
\hline Deslocamento $(\mathrm{cm})$ & 5,60 & 3,26 \\
\hline$\gamma_{z}$ & 1,05 & 1,08 \\
\hline$\alpha$ & 0,56 & 0,66 \\
\hline
\end{tabular}

TABELA 4.4 - Caixotes por pavimento.

\begin{tabular}{|l|l|}
\hline Caixotes por pavimento & 436 \\
\hline
\end{tabular}

\subsubsection{ALTERNATIVA UTILIZANDO TIJOLOS COMO MATERIAL INERTE}

A utilização dos tijolos deve-se principalmente à facilidade de aquisição deles. A principal desvantagem dos tijolos é que aumentam o peso próprio da estrutura, e uma das vantagens apresentadas neste sistema é que o material inerte existente é melhor isolante térmico que o concreto.

A laje nervurada formada com a utilização desses tijolos, conforme a figura 4.8, terá uma altura equivalente de inércia $h_{i}=15,07 \mathrm{~cm}$, e uma altura equivalente de consumo $h_{c}=8,02 \mathrm{~cm}$. O peso permanente acrescido às lajes por esses tijolos foi calculado como $0,95 \mathrm{kN} / \mathrm{m}^{2}$.

\section{a) Processo construtivo}

Para que eles componham a laje nervurada como material inerte, deve-se garantir que eles estejam vedados. Pode-se vedá-los com argamassa ou ensacá-los. Será considerado que eles estejam ensacados, já que ficam mais leves. Caso contrário devem ser suficientemente molhados para evitar a absorção de água do concreto, que provoca necessidade de aumento na relação águacimento e diminuição da resistência do concreto.

A colocação de dutos deve ser feita na região das nervuras (transversalmente a elas), pois, se efetuada por cima dos tijolos, reduzirá a espessura da mesa comprimida, que já é muito delgada. 

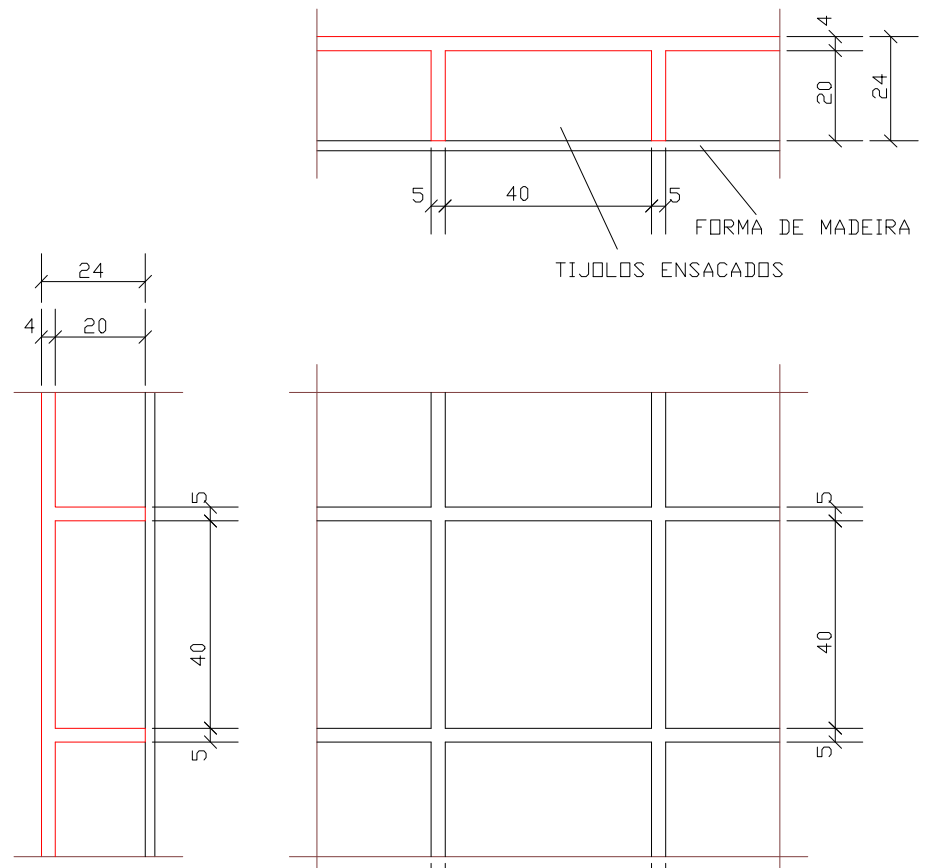

TIJULOS ENSACADES

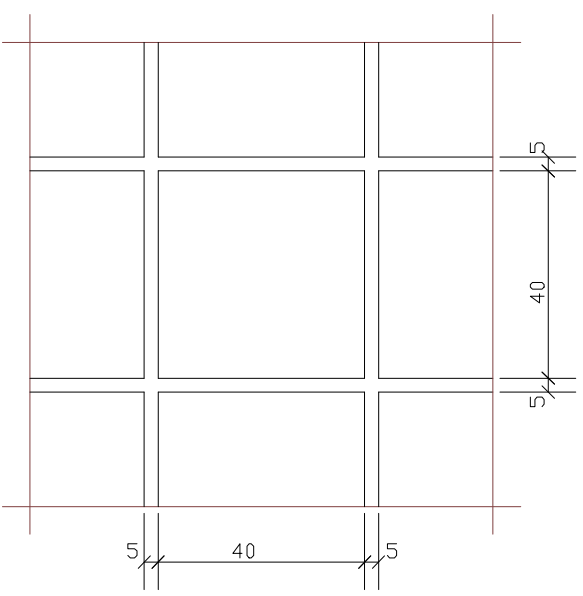

FIG. 4.8 - Corte transversal da alternativa utilizando tijolos.

b) Resultados

Os resultados relativos à estrutura com lajes nervuradas utilizando tijolos estão indicados nas tabelas 4.5, 4.6, 4.7 e 4.8.

TABELA 4.5 - Consumos de materiais.

\begin{tabular}{|c|c|c|c|}
\cline { 2 - 4 } \multicolumn{1}{c|}{} & $\begin{array}{c}\text { VOL. CONCRETO } \\
\left(\mathrm{m}^{3}\right)\end{array}$ & $\begin{array}{c}\text { AÇO } \\
(\mathrm{kg})\end{array}$ & $\begin{array}{c}\text { ÁREA DE FORMA } \\
\left(\mathrm{m}^{2}\right)\end{array}$ \\
\hline LAJES & 353,0 & 17.280 & $4.327,4$ \\
\hline VIGAS & 190,8 & 31.515 & $2.773,8$ \\
\hline PILARES & 206,8 & 22.462 & $1.872,0$ \\
\hline TOTAL & 750,6 & 71.257 & $8.973,2$ \\
\hline
\end{tabular}

TABELA 4.6 - Índices.

\begin{tabular}{|c|c|c|c|}
\hline $\begin{array}{c}\text { ESP. MÉDIA } \\
(\mathrm{cm})\end{array}$ & $\begin{array}{c}\text { TAXA DE AÇO } \\
\left(\mathrm{kg} / \mathrm{m}^{3}\right)\end{array}$ & $\begin{array}{c}\text { TX. DE AÇO II } \\
\left(\mathrm{kg} / \mathrm{m}^{2}\right)\end{array}$ & $\begin{array}{c}\text { TX. FORMA } \\
\left(\mathrm{m}^{2} / \mathrm{m}^{2}\right)\end{array}$ \\
\hline 14,78 & 94,93 & 14,03 & 1,77 \\
\hline
\end{tabular}


TABELA 4.7 - Deslocamentos e parâmetros de instabilidade.

\begin{tabular}{|c|c|c|}
\cline { 2 - 3 } \multicolumn{1}{c|}{} & Direção $Y$ & Direção $X$ \\
\hline Deslocamento $(\mathrm{cm})$ & 5,60 & 3,26 \\
\hline$\gamma_{z}$ & 1,06 & 1,08 \\
\hline$\alpha$ & 0,58 & 0,69 \\
\hline
\end{tabular}

TABELA 4.8 - Tijolos por pavimento.

Tijolos por pavimento 7.320

\subsubsection{ALTERNATIVA UTILIZANDO LAJES PRÉ-FABRICADAS}

Esta alternativa estrutural foi concebida utilizando o sistema laje treliçada bidirecional, que segundo FRANCA (1997) tem como características básicas o fato de possuírem nervuras resistentes em duas direções ortogonais. Essas nervuras são constituídas por vigotas pré-fabricadas treliçadas, dispostas na direção do menor vão da laje, e por nervuras transversais moldadas no local, armadas com barras isoladas de aço (figura 4.9). Para a confecção das nervuras transversais serão utilizadas plaquetas pré-moldadas e o elemento inerte será 0 bloco de poliestireno expandido (EPS).

As lajes pré-fabricadas com vigotas treliçadas apresentam como vantagens:

- rapidez de execução;

- economia de formas (já que as lajes não necessitam de formas) e de escoramento.

Como desvantagens podem ser apontados:

- o transporte, se a obra for longe da fábrica;

- os equipamentos necessários para o içamento das peças. 

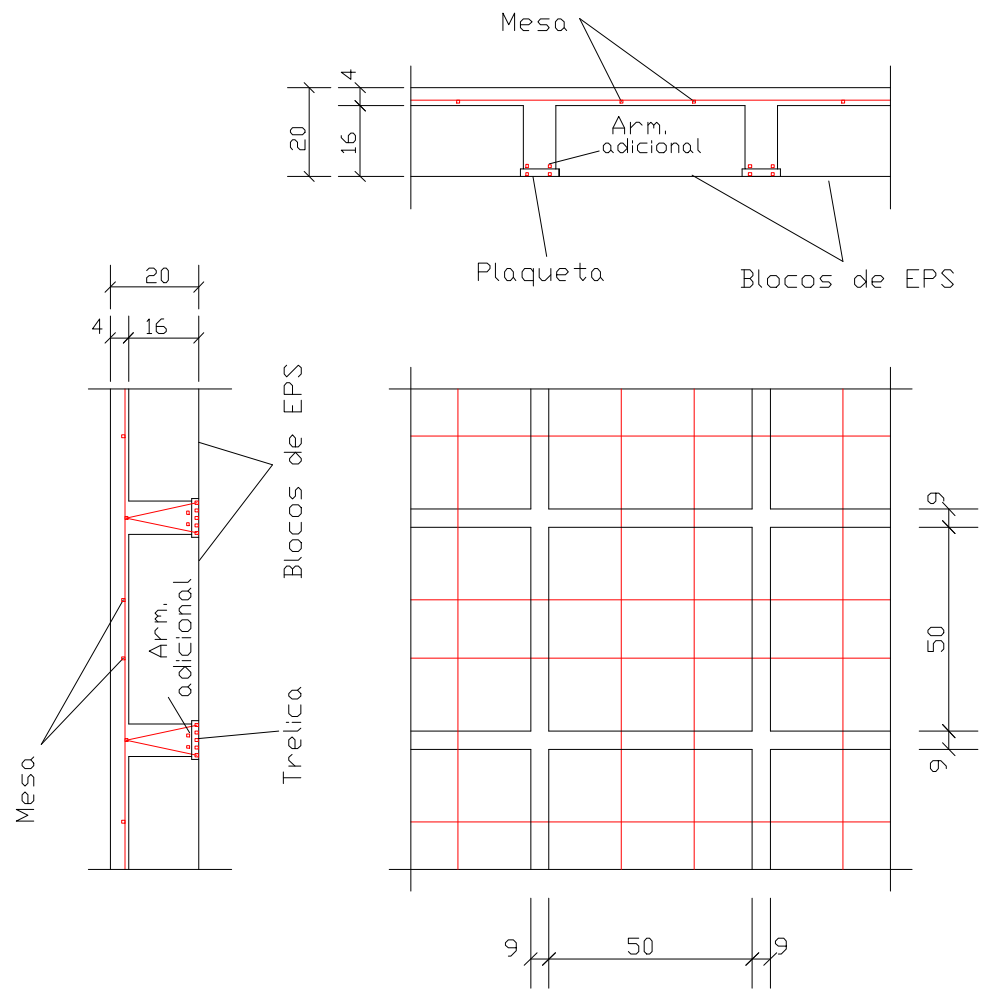

FIG. 4.9 - Laje treliçada bidirecional.

\section{a) Plaqueta}

A plaqueta é formada por uma delgada placa de concreto armado, que dispõe de garras de aço que permitem a sua fácil montagem. As garras são prolongamentos das armaduras da placa de concreto (figura 4.10). A plaqueta tem como função principal permitir a construção de lajes nervuradas pré-fabricadas bidirecionais. Ela possibilita a concretagem das nervuras transversais, sustentando a armadura e o concreto destas nervuras durante a fase de construção.

A fabricação das plaquetas é simples e pode ser feita no canteiro ou na indústria. Elas podem ser facilmente empilhadas e manuseadas, diminuindo o custo de seu transporte e armazenamento.

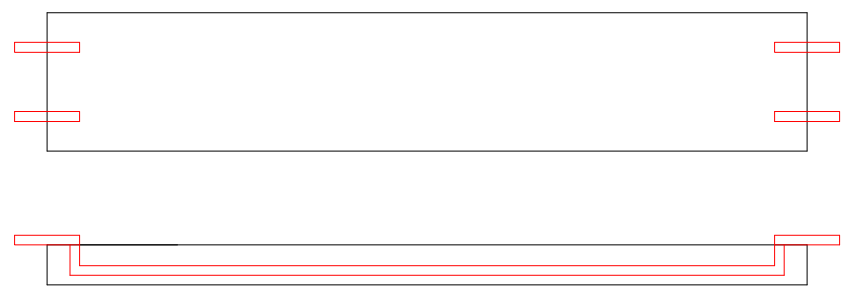

FIG. 4.10 - Plaqueta. 


\section{b) Blocos de EPS}

Os blocos de EPS (poliestireno expandido) são extremamente leves $\left(\gamma=0,1 \mathrm{kN} / \mathrm{m}^{3}\right)$, contêm $98 \%$ de ar e $2 \%$ de poliestireno, proporcionam alívio de cargas, redução de formas e mão-de-obra. Outras vantagens são:

- ótimo isolante termo-acústico;

- diminui a interferência da temperatura externa;

- deixa o teto pronto para receber o acabamento;

- tem baixa absorção de água;

- recebem bem a aplicação do chapisco;

- resiste bem à compressão;

- o corte pode ser feito na obra e é muito preciso;

- facilidade e economia no transporte;

- as instalações podem passar por dentro do EPS; o rasgo é feito facilmente com um secador quente.

\section{c) Processo construtivo}

A montagem se dá com o posicionamento das vigotas sobre 0 cimbramento; posteriormente é feita a colocação alternada dos blocos e das plaquetas. Essa operação é rápida e de baixo custo, devido à padronização do sistema.

Depois dessas fases faz-se a montagem da armadura complementar e a concretagem das nervuras e da capa. A concretagem poderá ser feita com concreto usinado bombeado diretamente sobre a laje.

A barra de aço superior e as barras diagonais da treliça têm por finalidade básica dotar as vigotas de resistência suficiente para enfrentar as solicitações advindas do manuseio, montagem e concretagem. Por isso devem-se colocar pontaletes e escoras na direção transversal das treliças para Ihes darem apoio.

A figura 4.11 mostra uma laje nervurada treliçada bidirecional com a utilização de blocos de EPS acabada. 


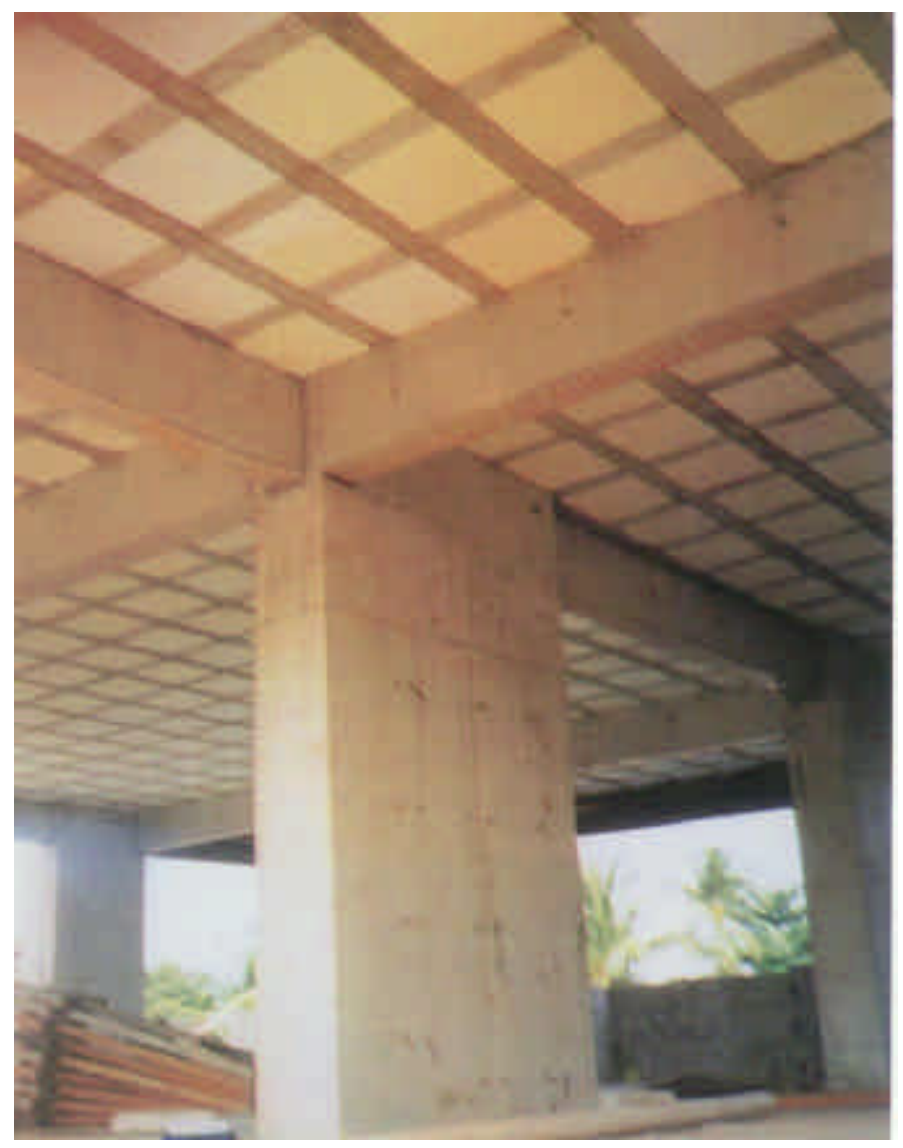

FIG. 4.11 - Laje nervurada treliçada bidirecional. (FRANCA, 1997)

\section{d) Dimensionamento}

Recomenda-se que a altura $(\mathrm{H})$ adotada para a laje esteja compreendida no intervalo $\frac{\mathrm{L}}{40} \leq \mathrm{H} \leq \frac{\mathrm{L}}{30}$, onde $\mathrm{L}$ é o menor vão da laje. Como no edifício-exemplo $\mathrm{L}=7,0 \mathrm{~m}, 17,5 \leq \mathrm{H} \leq 23$, e a altura adota foi $\mathrm{H}=20 \mathrm{~cm}$.

A laje é calculada como uma laje nervurada. Acrescenta-se às treliças e às plaquetas uma armadura adicional, de acordo com o necessário. A treliça adotada foi a tr16646, que já possui um $A_{s}=0,566 \mathrm{~cm}^{2}$ ( 6 barras de $4,2 \mathrm{~mm}$ ), e a plaqueta possui um $A_{s}=0,16 \mathrm{~cm}^{2}$ ( 2 barras de $4,2 \mathrm{~mm}$ ).

\section{e) Resultados}

Os resultados relativos à estrutura com lajes pré-fabricadas estão indicados nas tabelas 4.9, 4.10, 4.11 e 4.12. 
TABELA 4.9 - Consumos de materiais.

\begin{tabular}{|c|c|c|c|}
\cline { 2 - 4 } \multicolumn{1}{c|}{} & $\begin{array}{c}\text { VOL. CONCRETO } \\
\left(\mathrm{m}^{3}\right)\end{array}$ & $\begin{array}{c}\text { AÇO } \\
(\mathrm{kg})\end{array}$ & $\begin{array}{c}\text { ÁREA DE FORMA } \\
\left(\mathrm{m}^{2}\right)\end{array}$ \\
\hline LAJES & $337,28^{*}$ & $12.620^{* *}$ & 567,80 \\
\hline VIGAS & 190,80 & 30.523 & $2.773,80$ \\
\hline PILARES & 206,80 & 19.965 & $1.872,00$ \\
\hline TOTAL & 734,88 & 63.108 & $5.213,60$ \\
\hline
\end{tabular}

*Esse valor é referente ao volume de concreto das nervuras e da mesa, não levando em consideração a base da vigota nem a plaqueta.

${ }^{* *}$ Esse valor é referente à armadura complementar colocada nas vigotas e nas plaquetas.

TABELA 4.10 - Índices.

\begin{tabular}{|c|c|c|c|}
\hline $\begin{array}{c}\text { ESP. MÉDIA } \\
(\mathrm{cm})\end{array}$ & $\begin{array}{c}\text { TAXA DE AÇO } \\
\left(\mathrm{kg} / \mathrm{m}^{3}\right)\end{array}$ & $\begin{array}{c}\text { TX. DE AÇO II } \\
\left(\mathrm{kg} / \mathrm{m}^{2}\right)\end{array}$ & $\begin{array}{c}\text { TX. FORMA } \\
\left(\mathrm{m}^{2} / \mathrm{m}^{2}\right)\end{array}$ \\
\hline 14,46 & 85,88 & 12,42 & 1,03 \\
\hline
\end{tabular}

TABELA 4.11 - Deslocamentos e parâmetros de instabilidade.

\begin{tabular}{|c|c|c|}
\cline { 2 - 3 } \multicolumn{1}{c|}{} & Direção $Y$ & Direção $X$ \\
\hline Deslocamento $(\mathrm{cm})$ & 5,60 & 3,26 \\
\hline$\gamma_{z}$ & 1,05 & 1,08 \\
\hline$\alpha$ & 0,56 & 0,66 \\
\hline
\end{tabular}

As peças necessárias para a composição desse sistema estrutural são: vigotas treliçadas, plaquetas e blocos de EPS. Seus quantitativos por pavimento são apresentados na tabela 4.12 .

TABELA 4.12 - Elementos pré-fabricados.

\begin{tabular}{|c|c|}
\hline Blocos de EPS & 483 \\
\hline Plaquetas & 538 \\
\hline $\operatorname{tr} 16646(\mathrm{c}=6,90 \mathrm{~m})$ & 26 \\
\hline $\operatorname{tr} 16646(\mathrm{c}=5,70 \mathrm{~m})$ & 32 \\
\hline
\end{tabular}




\section{ESTRUTURA COM LAJE LISA NERVURADA}

\subsection{LAJES LISAS}

De acordo com a revisão da NB-1 (1997), "lajes cogumelo são lajes apoiadas diretamente em pilares, com capitéis, enquanto lajes lisas são as apoiadas nos pilares sem capitéis."

Esse tipo de sistema estrutural (figura 5.1) apresenta uma versatilidade muito grande à concepção arquitetônica, já que a ausência de vigas propicia uma liberdade maior a mudanças no "layout" dos pavimentos.

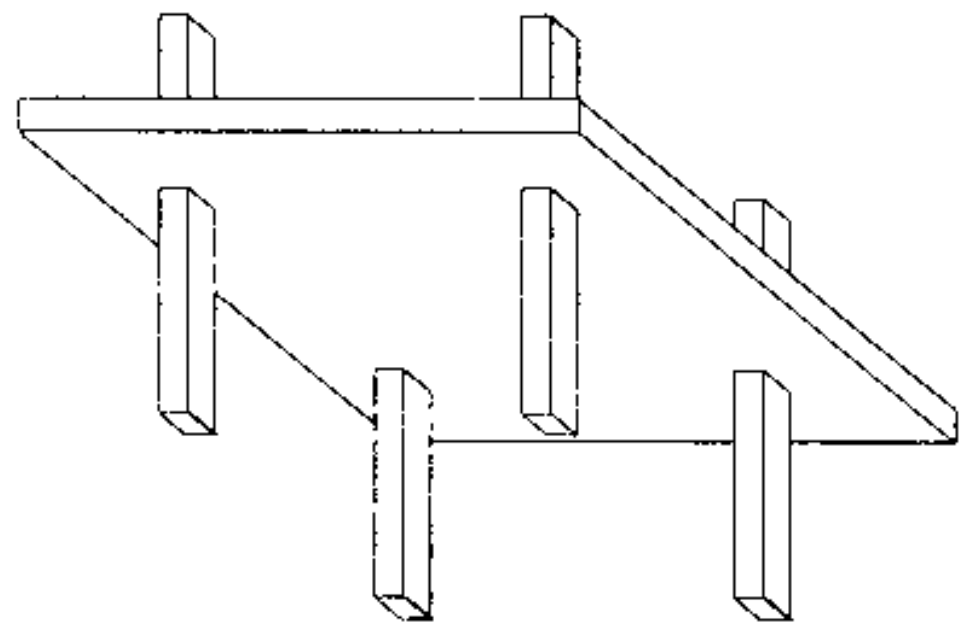

FIG. 5.1 - Laje lisa. (MELGES, 1995)

"As lajes-cogumelo foram introduzidas por Turner, em 1905, nos Estados Unidos da América, país onde ocorreu também o primeiro acidente grave com esse tipo de estrutura: o desabamento do Prest-O-Lite Building, em Indianápolis, Indiana, em dezembro de 1911, matando nove pessoas e ferindo gravemente vinte" (BRANCO, 1989). 
Nas primeiras lajes sem vigas era comum o uso de capitéis, visando ao enrijecimento da ligação laje-pilar, mas isto prejudicava uma das suas principais vantagens, que é a ausência de recortes na forma do pavimento. Com o desenvolvimento do sistema, abandonou-se o uso de capitéis na maioria dos casos e passou-se a fazer uma criteriosa verificação da punção. As lajes lisas podem ser maciças ou nervuradas; caso sejam nervuradas a região em torno do pilar será maciça (capitel embutido).

No início este sistema estrutural era analisado simplificadamente com o processo dos pórticos múltiplos, evoluiu paralelamente à evolução do uso da informática em problemas de Engenharia e passou a ser analisado por técnicas mais refinadas, tais como: diferenças finitas, método dos elementos finitos e elementos de contorno. A revisão da NB-1 (1997) ainda permite o cálculo através do processo dos pórticos múltiplos, mas apenas para situações muito particulares.

Com a utilização mais freqüente das lajes lisas, observou-se que a utilização de vigas nas bordas do pavimento traziam uma série de vantagens, sem com isso prejudicar o conceito da ausência de recortes na forma do pavimento:

- Não prejudicam a arquitetura;

- Formam pórticos para resistir as ações laterais;

- Impedem deslocamentos excessivos nas bordas;

- Eliminam a necessidade de verificação de punção em alguns pilares.

Em alguns casos especiais, fica difícil a colocação de vigas nas bordas do pavimento, mas na grande maioria dos edifícios não há porque não usar.

\subsubsection{Diretrizes para projeto}

A Construtora ENCOL elaborou um conjunto de diretrizes para projetos em lajes planas (lajes lisas) nervuradas. Essas diretrizes, que serão parcialmente mencionadas a seguir, visam a garantir segurança, condições construtivas e otimização da estrutura. 


\section{a) Pilares}

Para a locação dos pilares internos, a área de influência de laje para cada pilar deverá ser entre 85 e $100 \mathrm{~m}^{2}$. Deverá ser considerado no dimensionamento o momento que aparece na ligação laje-pilar.

\section{b) Lajes}

As barras das armaduras deverão obedecer aos seguintes limites:

- Diâmetro da armadura negativa na mesa menor ou igual a 6,3 mm;

- Diâmetro da armadura superior na nervura menor ou igual a 10,0 mm;

- Diâmetro da armadura inferior na nervura menor ou igual a 12,5 mm;

- Para as armaduras inferiores das nervuras dever-se-ão evitar mais de duas barras por nervura;

- A distribuição das armaduras negativas deve ser $70 \%$ nas nervuras e $30 \%$ na mesa;

- Deverá ser colocada armadura na mesa das lajes nervuradas, para combater momentos volventes nos cantos das lajes, com diâmetro menor ou igual a $6,3 \mathrm{~mm}$.

As lajes nervuradas deverão ser dimensionadas de tal forma que não se utilize armadura de cisalhamento nas nervuras, que já é um indicativo das dimensões maciças nas regiões adjacentes ao pilar (capitel embutido).

\subsubsection{Punção}

"O fenômeno da punção de uma placa é basicamente a sua perfuração devida às altas tensões de cisalhamento, provocadas por forças concentradas ou agindo em pequenas áreas. Nos edifícios com lajes-cogumelo, esta forma de ruína pode se dar na ligação da laje com os pilares, onde a reação do pilar pode provocar a perfuração da laje" (MELGES,1995).

Em várias normas a verificação da punção é baseada no método da superfície de controle, que consiste no cálculo de uma tensão nominal de cisalhamento em uma determinada superfície de controle. Com o valor dessa 
tensão e o da resistência do concreto, faz-se uma verificação. A revisão da NB-1 (1997) adota esse modelo de cálculo e considera como superfície de controle a região paralela ao pilar distante $2 d$ da face do mesmo (perímetro crítico, figura 5.2).

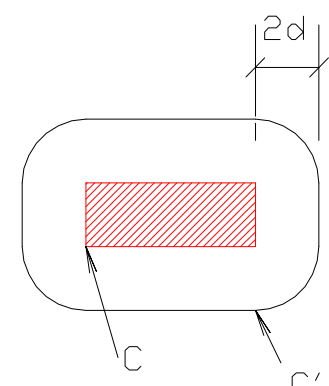

FIG. 5.2 - Perímetro crítico.

$$
\tau_{S d}=\frac{F_{S d}}{u \cdot d} \frac{K \cdot M_{S d}}{W_{P} \cdot d} \leq \tau_{R d 1}
$$

$\tau_{S d}=$ tensão atuante de cálculo;

$\tau_{\mathrm{Rd1}}=$ tensão resistente de cálculo;

$\mathrm{d} \quad=$ altura útil da laje ao longo do contorno crítico $C^{\prime}$, externo ao contorno $C$ da área de aplicação de força e deste distante $2 \mathrm{~d}$ no plano da laje;

$\mathrm{d}=\left(d_{x}+d_{y}\right) / 2$, sendo $d_{x}$ e $d_{y}$ as alturas úteis nas duas direções ortogonais;

$\mathrm{u}=$ perímetro do contorno crítico $\mathrm{C}^{\prime}$;

u.d = área da superfície crítica;

$\mathrm{F}_{\mathrm{Sd}}=$ força ou reação concentrada de cálculo ;

$\mathrm{K}$ = coeficiente que fornece a parcela do $\mathrm{M}_{\mathrm{Sd}}$ transmitida ao pilar por cisalhamento, que depende da relação $c_{1} / c_{2}$;

$\mathrm{C}_{1} \quad$ dimensão do pilar paralela à excentricidade da força;

$\mathrm{C}_{2} \quad$ = dimensão do pilar perpendicular à excentricidade;

$\mathrm{M}_{\mathrm{Sd}}=$ momento de cálculo aplicado pela laje ao pilar; caso o efeito do carregamento possa ser considerado simétrico $\mathrm{M}_{\mathrm{Sd}}=0$;

$\mathrm{W}_{\mathrm{P}}$ = parâmetro referente ao perímetro crítico $\mathrm{u}$, definido como módulo de resistência plástica do perímetro crítico. Pode ser calculado desprezando a curvatura dos cantos do perímetro crítico; 
$W_{P}=\int_{0}^{u} e \cdot d l$

$W_{P}=\frac{c_{1}^{2}}{2}+c_{1} c_{2}+4 c_{2} d+16 d^{2}+2 \pi \cdot d \cdot c_{1} \quad$ (pilar retangular)

$\mathrm{dl}=$ comprimento infinitesimal do perímetro crítico $\mathrm{u}$;

e $\quad=$ distância de dl ao eixo que passa pelo centro do pilar e sobre o qual atua o momento fletor $\mathrm{M}_{\mathrm{Sd}}$.

\subsubsection{Modelo de cálculo das lajes lisas}

A revisão da NB-1 (1997) preconiza que a análise estrutural de lajes lisas deve ser efetuada via: diferenças finitas, elementos finitos ou elementos de contorno. Permite ainda, para casos em que os pilares estiverem dispostos em filas ortogonais, de maneira regular com vãos pouco diferentes, a utilização de processos simplificados para o cálculo, que consistem em adotar pórticos múltiplos para cada direção.

O processo dos pórticos múltiplos fica, em vários casos, difícil de ser usado, pelo fato de os edifícios não se enquadrarem nas prescrições da norma e também pelo fato de alguns projetistas alegarem ser um método impreciso.

Em contrapartida, a existência de softwares que possibilitam a análise estrutural pelo método dos elementos finitos e a confiabilidade desse método fizeram com que esse processo fosse o mais difundido para o cálculo das lajes lisas. Alguns comentários já foram feitos sobre a analogia de grelha no item 4.1.4; seguem alguns indicativos sobre o método dos elementos finitos.

\section{a) Elementos finitos}

A análise estrutural tem evoluído bastante com 0 avanço da microinformática. Os novos computadores têm permitido processamentos sofisticados em um pequeno período de tempo. Isto possibilitou a utilização de recursos de modelagem que até então pareciam impossíveis de ser aplicados na prática, ficando restritos ao meio acadêmico. Um bom exemplo é o emprego do método dos elementos finitos, que se faz presente em vários softwares disponíveis no mercado. 
O MEF teve seu desenvolvimento nas últimas quatro décadas e já se firma como uma das mais importantes ferramentas na Engenharia. "O conceito básico consiste em se considerar o meio contínuo como um conjunto de componentes estruturais individuais interconectados por um número finito de pontos" (BAPTISTA, 1994). Essa divisão da estrutura em componentes menores e a ligação entre eles através de seus nós proporciona ao modelo matemático a possibilidade de uma semelhança maior com o modelo físico, já que o pavimento será discretizado como um todo, obrigando que todos os elementos se deformem em conjunto. Ocorre o contrário do que acontecia em outras modelagens, em que as lajes eram consideradas isoladas das vigas, ou ainda, como no caso da viga contínua, não se consideravam os deslocamentos dos apoios indiretos.

É importante salientar que embora o MEF esteja acessível para os projetistas, a sua utilização requer uma conscientização, por parte do usuário, do funcionamento do método, dos seus dados de entrada e de seus dados de saída. O engenheiro não deve tornar-se um operador de máquinas e perder seu senso de análise. Várias vantagens do MEF são ressaltadas por CORRÊA \& RAMALHO (1993):

- Tratamento mais realista do carregamento - às vezes essa vantagem não é muito usual na prática, devido a possíveis variações no "layout" dos pavimentos, uma mudança na posição de paredes, por exemplo;

- Representação da rigidez relativa laje-viga-pilar - é uma das principais vantagens do método, tornando a representação matemática mais próxima do modelo físico;

- Modelagem de aberturas em laje e de formas não retangulares das lajes;

- Simulação automática da continuidade dos painéis de laje;

- Representação de enrijecedores excêntricos;

- Possibilidade de uma armação mais racional;

- Caminhamento mais real da carga, fornecendo esforços menores;

- Possibilidade de alteração das espessuras e das características do material da laje em cada elemento.

A dificuldade do método consiste na grande quantidade de dados de entrada e de saída, o que pode ser resolvido com o desenvolvimento de pré- 
processadores e pós-processadores eficientes, com excelentes recursos gráficos para facilitar a visualização dos dados.

\section{b) Definição da malha de elementos finitos}

A definição das malhas de elementos finitos para um modelo de placa deve ser realizada com o objetivo de atender a três condições básicas:

- Que a malha consiga representar bem a geometria do modelo;

- O modelo matemático deve ficar o mais próximo possível do modelo físico;

- A malha deve ser suficientemente refinada, a fim de que os campos de deslocamento e solicitações atuantes no modelo possam ser interpolados de maneira precisa, a partir das incógnitas nodais e de suas derivadas.

Deve-se tentar ao máximo deixar a malha homogênea, ou ainda, quando necessário, deve variar suavemente através do domínio. Deve-se também ter em mente que o centro de gravidade da barra não coincide com o eixo de gravidade da placa e, ao discretizar o pavimento em elementos finitos, esta excentricidade não é considerada, com isso obrigando que o eixo da laje coincida com o eixo da viga, o que na maioria das vezes não é verdade.

Se alguns resultados são conhecidos previamente, torna-se relativamente mais fácil preparar um modelo adequado, já que se pode coincidir os vértices com os pontos da rede e colocar os nós em pontos estratégicos.

\subsection{ALTERNATIVAS ADOTADAS}

Essa alternativa se apresenta como a tendência do projeto estrutural (figura 5.4). Será concebida com laje nervurada, pois com laje maciça o consumo aumenta bastante. Serão analisadas lajes nervuradas com caixotes e lajes nervuradas com tijolos. Utilizar-se-ão vigas de borda por razões já expostas (item 5.1). A resistência do concreto nessa alternativa será $f_{c k}=35 \mathrm{MPa}$ (vigas e pilares) e $f_{c k}=25 \mathrm{MPa}$ (laje). Essa alteração do $f_{c k}$ da laje se deve às grandes deformações e aos altos esforços solicitantes nesses elementos. 
As regiões adjacentes aos pilares internos serão concretadas maciçamente, formando os chamados capitéis embutidos (figura 5.3), devidos aos esforços de flexão sobre o pilar e ao puncionamento da laje. Os capitéis propriamente ditos praticamente não são mais usados, porque eliminam uma das principais vantagens desse sistema estrutural, que é a ausência de recortes na forma da laje.

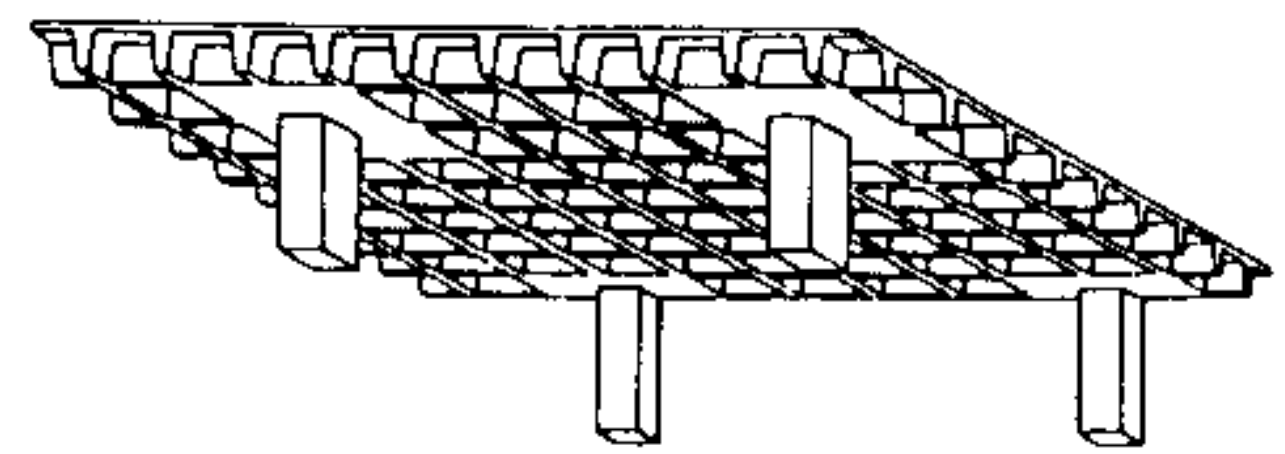

FIG. 5.3 - Laje lisa nervurada com capiteis embutidos. (MELGES, 1995)

As estruturas que utilizam laje lisa são muito apreciadas por arquitetos e projetistas de instalação. Para os construtores o problema é mais complexo, porque depende de uma série de variáveis. As vantagens apresentadas são:

- as formas apresentam um plano contínuo, com recortes apenas nas ligações com os pilares; por isso apresentam simplicidade na execução e na retirada das formas;

- menor consumo de madeira e menor incidência de mão-de-obra, para a confecção das formas; 


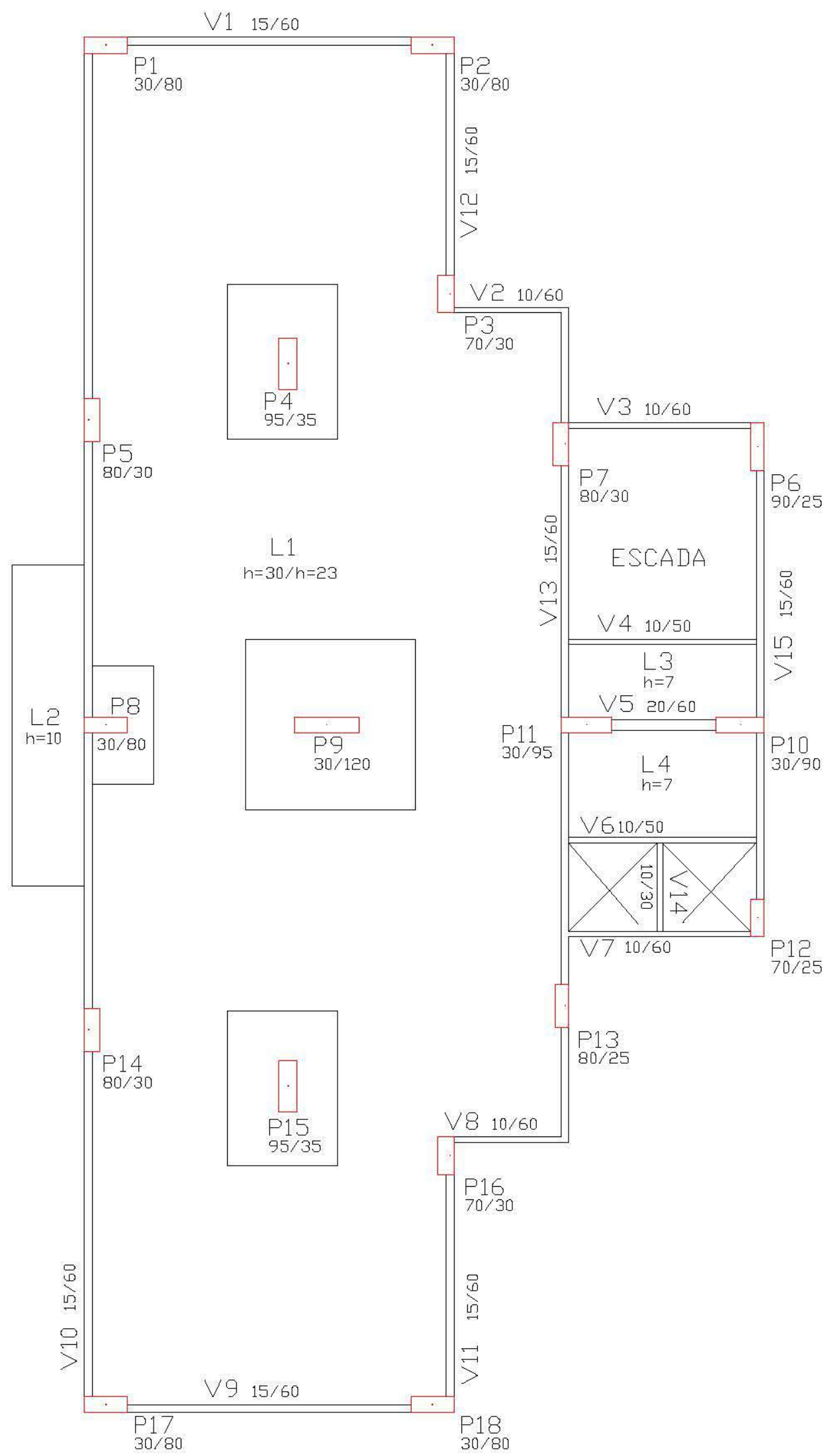

FIG. 5.4 - Forma da estrutura com laje lisa nervurada. 
- maior reaproveitamento da forma;

- facilidade na concretagem, pois possui um pano único;

- menor tempo de execução, diminuindo custos financeiros;

- maior versatilidade no pavimento devido à ausência de vigas, oferecendo ampla liberdade na definição dos espaços internos, que traduz um forte apelo comercial;

- economia nas instalações, já que o projeto e a execução das instalações são facilitados, pois diminui a quantidade de curvas e elimina a perfuração de vigas.

Essas vantagens, para realmente surtirem efeito, precisam de um certo preparo por parte do executor e dos projetistas, bem como uma melhor qualificação da mão-de-obra. Algumas desvantagens são:

- menor rigidez da estrutura às ações laterais em relação aos outros sistemas estruturais, devido ao número reduzido de pórticos. Em certos casos necessita-se da presença de núcleos rígidos na região da escada e dos poços de elevadores;

- puncionamento da laje pelos pilares;

- armação um pouco complicada, principalmente sobre os pilares e nas suas adjacências;

- em geral, maior consumo de aço e concreto.

\subsubsection{ALTERNATIVA UTILIZANDO CAIXOTES DE PROPILENO}

Como se trata de uma laje lisa, em que os esforços são maiores e tem o problema da punção, fez-se necessária a utilização de um caixote com maior inércia, conforme a figura 5.5 .

A laje nervurada constituída com esses caixotes tem uma altura equivalente de inércia $h_{i}=16,96 \mathrm{~cm}$, e uma altura equivalente de consumo $\mathrm{h}_{\mathrm{c}}=8,51 \mathrm{~cm}$.

Os resultados relativos à estrutura com laje lisa nervurada utilizando caixotes estão indicados nas tabelas 5.1, 5.2, 5.3 e 5.4. 

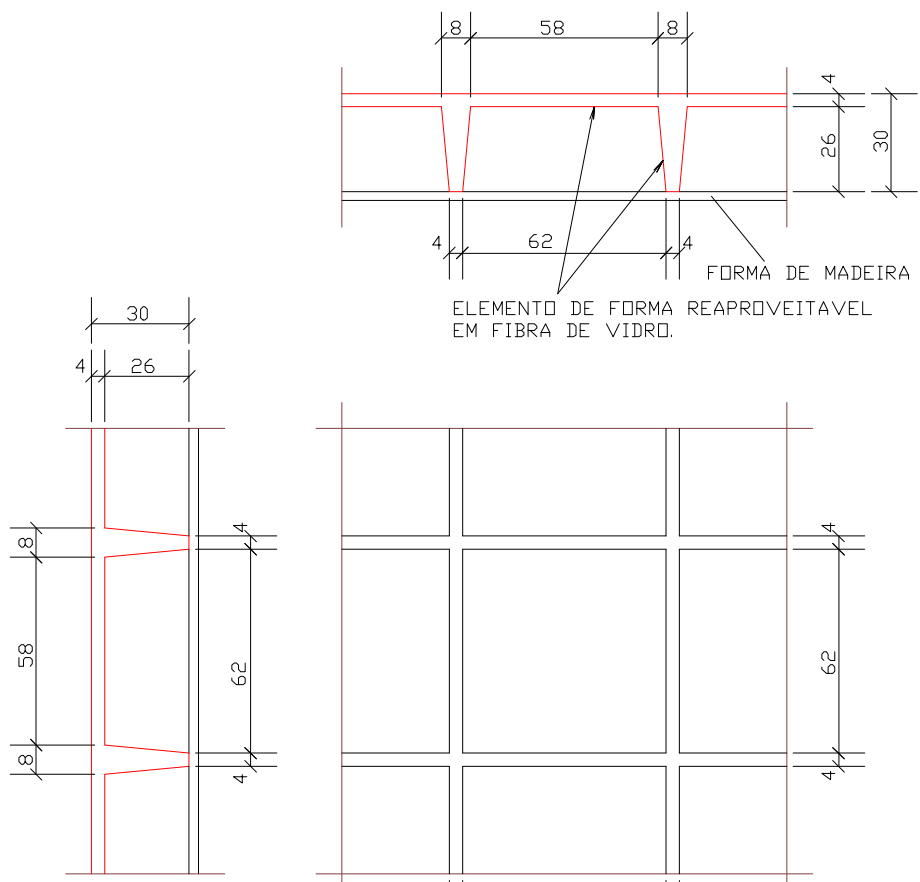

ELEMENTI DE FURMA REAPRQVEITAVEL
EM FIBRA IE VIDRD.

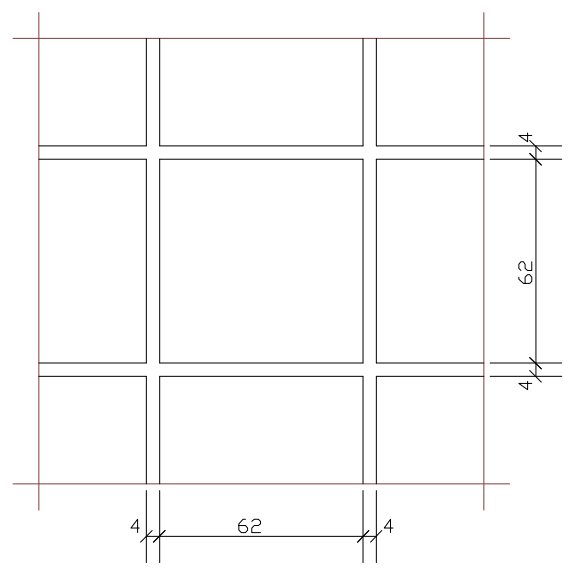

FIG. 5.5 - Corte transversal da alternativa utilizando caixotes.

TABELA 5.1 - Consumos de materiais.

\begin{tabular}{|c|c|c|c|}
\cline { 2 - 4 } \multicolumn{1}{c|}{} & $\begin{array}{c}\text { VOL. CONCRETO } \\
\left(\mathrm{m}^{3}\right)\end{array}$ & $\begin{array}{c}\text { AÇO } \\
(\mathrm{kg})\end{array}$ & $\begin{array}{c}\text { ÁREA DE FORMA } \\
\left(\mathrm{m}^{2}\right)\end{array}$ \\
\hline LAJES & 483,4 & 20.112 & $4.415,0$ \\
\hline VIGAS & 138,2 & 23.364 & $2.162,8$ \\
\hline PILARES & 260,4 & 26.910 & $2.361,6$ \\
\hline TOTAL & 882,0 & 70.386 & $8.938,4$ \\
\hline
\end{tabular}

TABELA 5.2 - Índices.

\begin{tabular}{|c|c|c|c|}
\hline $\begin{array}{c}\text { ESP. MÉDIA } \\
(\mathrm{cm})\end{array}$ & $\begin{array}{c}\text { TAXA DE AÇO } \\
\left(\mathrm{kg} / \mathrm{m}^{3}\right)\end{array}$ & $\begin{array}{c}\text { TX. DE AÇO II } \\
\left(\mathrm{kg} / \mathrm{m}^{2}\right)\end{array}$ & $\begin{array}{c}\text { TX. FORMA } \\
\left(\mathrm{m}^{2} / \mathrm{m}^{2}\right)\end{array}$ \\
\hline 17,36 & 79,80 & 13,86 & 1,76 \\
\hline
\end{tabular}


TABELA 5.3 - Deslocamentos e parâmetros de instabilidade.

\begin{tabular}{|c|c|c|}
\cline { 2 - 3 } \multicolumn{1}{c|}{} & Direção $Y$ & Direção $X$ \\
\hline Deslocamento $(\mathrm{cm})$ & 10,62 & 2,23 \\
\hline$\gamma_{z}$ & 1,09 & 1,05 \\
\hline$\alpha$ & 0,75 & 0,55 \\
\hline
\end{tabular}

TABELA 5.4 - Caixotes por pavimento.

\begin{tabular}{|l|l|}
\hline Caixotes por pavimento & 300 \\
\hline
\end{tabular}

\subsubsection{ALTERNATIVA UTILIZANDO TIJOLOS COMO MATERIAL INERTE}

Essa alternativa foi baseada nas dimensões recomendadas pelo caderno de encargos da construtora ENCOL.

A laje nervurada formada com a utilização de tijolos, conforme a figura 5.6, terá uma altura equivalente de inércia $h_{i}=16,24 \mathrm{~cm}$, e uma altura equivalente de consumo $h_{c}=10,34 \mathrm{~cm}$. O peso permanente acrescido na laje por esses tijolos foi calculado como $0,8 \mathrm{kN} / \mathrm{m}^{2}$.
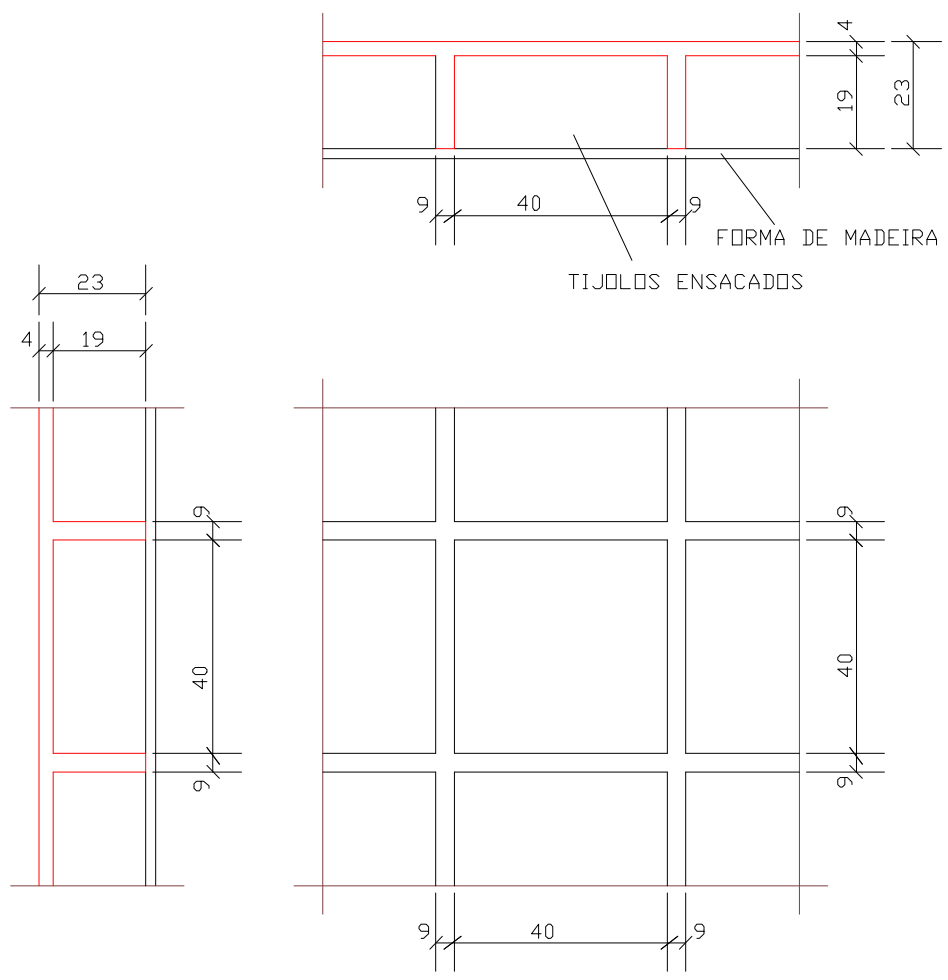

FIG. 5.6 - Corte transversal da alternativa utilizando tijolos. 
Os resultados relativos à estrutura com laje lisa nervurada utilizando tijolos estão indicados nas tabelas 5.5, 5.6, 5.7 e 5.8.

TABELA 5.5 - Consumos de materiais.

\begin{tabular}{|c|c|c|c|}
\cline { 2 - 4 } \multicolumn{1}{c|}{} & $\begin{array}{c}\text { VOL. CONCRETO } \\
\left(\mathrm{m}^{3}\right)\end{array}$ & $\begin{array}{c}\text { AÇO } \\
(\mathrm{kg})\end{array}$ & $\begin{array}{c}\text { ÁREA DE FORMA } \\
\left(\mathrm{m}^{2}\right)\end{array}$ \\
\hline LAJES & 498,2 & 28.408 & $4.415,0$ \\
\hline VIGAS & 138,2 & 23.947 & $2.162,8$ \\
\hline PILARES & 260,4 & 24.915 & $2.361,6$ \\
\hline TOTAL & 896,8 & 77.270 & $8.938,4$ \\
\hline
\end{tabular}

TABELA 5.6 - Índices.

\begin{tabular}{|c|c|c|c|}
\hline $\begin{array}{c}\text { ESP. MÉDIA } \\
(\mathrm{cm})\end{array}$ & $\begin{array}{c}\text { TAXA DE AÇO } \\
\left(\mathrm{kg} / \mathrm{m}^{3}\right)\end{array}$ & $\begin{array}{c}\text { TX. DE AÇO II } \\
\left(\mathrm{kg} / \mathrm{m}^{2}\right)\end{array}$ & $\begin{array}{c}\text { TX. FORMA } \\
\left(\mathrm{m}^{2 /} \mathrm{m}^{2}\right)\end{array}$ \\
\hline 17,65 & 86,16 & 15,21 & 1,76 \\
\hline
\end{tabular}

TABELA 5.7 - Deslocamentos e parâmetros de instabilidade.

\begin{tabular}{|c|c|c|}
\cline { 2 - 3 } \multicolumn{1}{c|}{} & Direção $Y$ & Direção $X$ \\
\hline Deslocamento $(\mathrm{cm})$ & 10,30 & 2,23 \\
\hline$\gamma_{z}$ & 1,10 & 1,06 \\
\hline$\alpha$ & 0,79 & 0,57 \\
\hline
\end{tabular}

TABELA 5.8 - Tijolos por pavimento.

\begin{tabular}{|c|c|}
\hline Tijolos por pavimento & 5.648 \\
\hline
\end{tabular}




\section{ESTRUTURA UTILIZANDO PROTENSÃO}

\subsection{PROTENSÃO COM MONOCORDOALHAS ENGRAXADAS}

Segundo a NBR-7197 (1989), concreto protendido sem aderência é aquele em que, após o estiramento da armadura de protensão, não é criada aderência com o concreto. Esse sistema de protensão não aderente apresenta-se como uma ótima alternativa para aplicações em lajes e vigas de edifícios, que requerem uma protensão "leve".

De acordo com AALAMI (1994) esse sistema vem sendo usado nos Estados Unidos desde 1950. Consiste em protensão não aderente formada por bainhas com única cordoalha (figura 6.1).

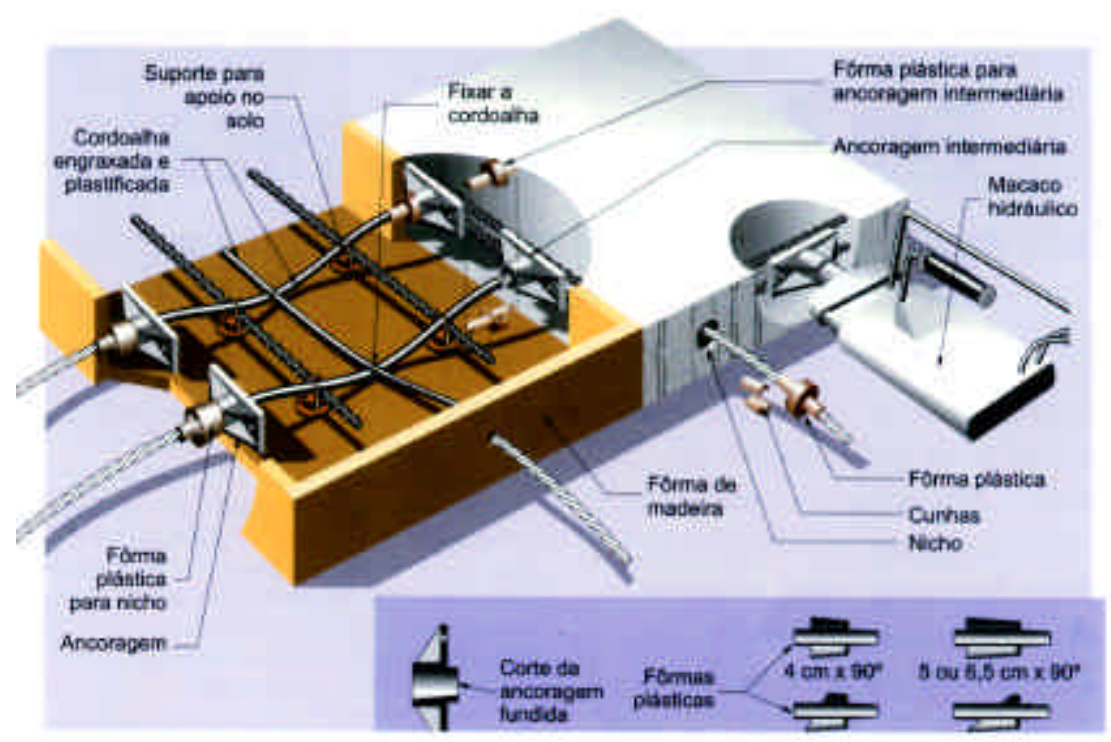

FIG. 6.1 - Montagem típica de uma laje com monocordoalhas.

A monocordoalha é envolvida por uma graxa especial, que funciona como protetora e inibidora da corrosão. A graxa fornece ainda excelente lubrificação entre a cordoalha e a bainha, reduzindo o atrito. As bainhas são de plástico extrudadas, feitas de polietileno de alta densidade com espessura mínima 
de $1 \mathrm{~mm}$, e oferecem excelente resistência ao manuseio e ao arraste por entre as ferragens frouxas existentes. Além da praticidade do manuseio, elimina-se a constante preocupação com a integridade da bainha metálica, durante seu posicionamento nas formas, para se evitarem amassamentos ou entrada de nata de cimento que possa prender a cordoalha.

Pelo fato de serem monocordoalhas, terão ancoragens individuais (figura 6.2). Devido ao baixo atrito, cada cordoalha leva uma ancoragem préencunhada (ancoragem passiva) e uma ancoragem que será protendida após a concretagem (ancoragem ativa). As monocordoalhas minimizam ainda o problema de concentração de tensões e fendilhamento.

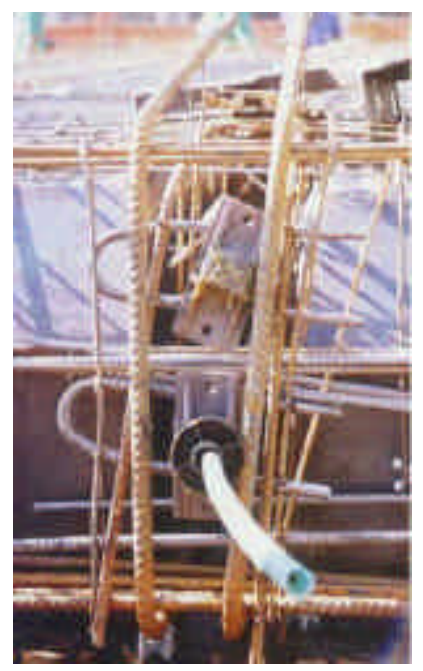

FIG. 6.2 - Ancoragens passiva e ativa.

A protensão é feita rapidamente por um macaco hidráulico portátil de pequenas dimensões (figura 6.3), e é feita por um único operador. A força de protensão é transmitida ao concreto através de suas ancoragens, cuja durabilidade é fundamental para o bom desempenho desse sistema ao longo da vida útil.

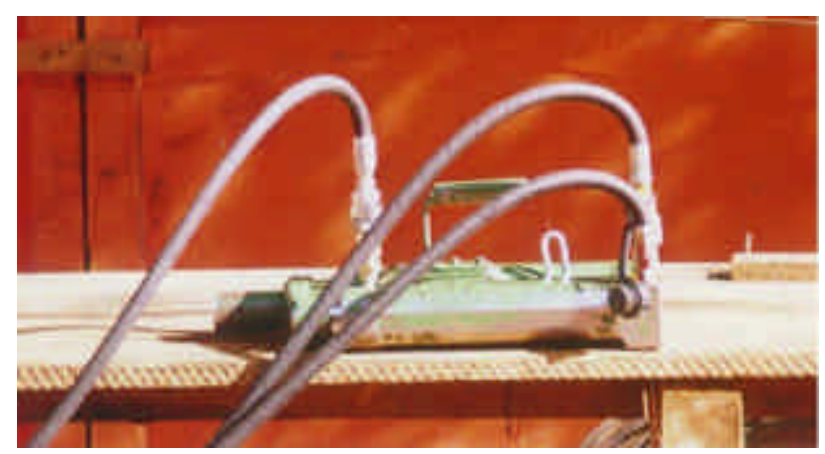

FIG. 6.3 - Macaco hidráulico. 
Várias vantagens são ressaltadas por CAUDURO (1997) na protensão sem aderência:

- maior facilidade e rapidez no posicionamento das cordoalhas nas formas;

- maior excentricidade possível (importante nas lajes finas);

- o aço já chega ao canteiro protegido pela graxa e pela capa plástica;

- menor perda por atrito;

- ausência de operação de injeção de pasta de cimento;

- cordoalha danificada, ao longo da sua vida útil, pode ser substituída.

Algumas desvantagens são verificadas:

- apesar de ser usado há mais de 45 anos nos Estados Unidos, o processo ainda está iniciando-se no Brasil;

- a norma brasileira prevê a solução, mas dificulta porque exige protensão completa, obrigando a adoção de normas internacionais;

- não se pode cortar a monocordoalha;

- custo da protensão ainda alto, pelo pouco volume de aplicação.

Segundo MOTA (1997), o traçado da cablagem engraxada é obtido normalmente pela técnica do balanceamento de cargas (load balancing method) proposto no início dos anos 60 por T.Y.Lin. Este procedimento é bastante eficiente no caso de cabos em lajes e vigas de edifícios, onde os traçados são obtidos pela concordância de parábolas suaves do segundo grau.

\subsubsection{Método do balanceamento de cargas}

Consiste em considerar a protensão como força externa aplicada para neutralizar parte do carregamento atuante na estrutura. Geralmente se procura neutralizar as ações permanentes ou as ações permanentes e parte das ações variáveis.

Chamam-se cargas equivalentes aquelas que correspondem ao conjunto de forças auto-equilibradas que produzem na estrutura o mesmo efeito da protensão. São portanto as reações concentradas nas ancoragens e as reações 
decorrentes da geometria dos cabos (figura 6.4). A carga uniformemente distribuída equivalente a um cabo parabólico é achada através das expressões:

$$
\begin{aligned}
& \mathrm{p}_{\mathrm{e} 0}=\frac{2 \mathrm{Pf}_{0}}{\left(\mathrm{~L}_{0}\right)^{2}} \\
& \mathrm{p}_{\mathrm{e} 1}=\frac{8 \mathrm{Pf}_{1}}{\left(\mathrm{~L}_{1}\right)^{2}}
\end{aligned}
$$

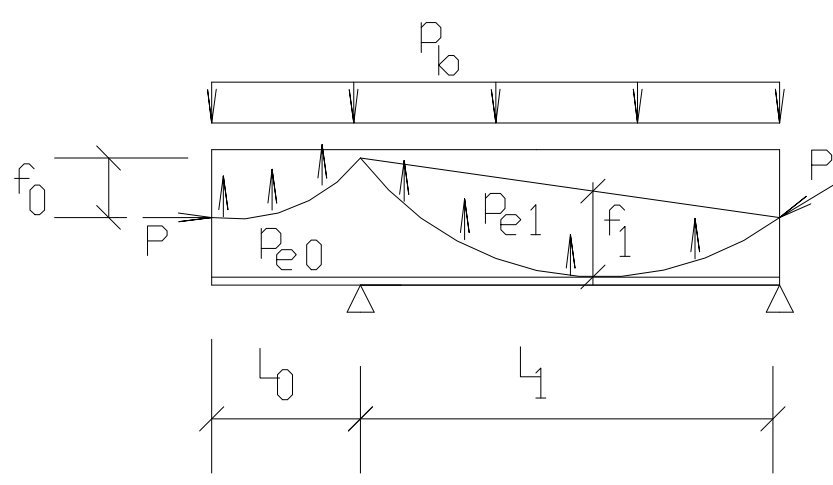

FIG. 6.4 - Cargas equivalentes à protensão (cabo com traçado parabólico).

P: força de protensão;

$\mathrm{p}_{\mathrm{b}}$ : carga a ser balanceada;

$\mathrm{p}_{\mathrm{e} 0}$ : carga equivalente uniformemente distribuída no balanço;

$\mathrm{p}_{\mathrm{e} 1}$ : carga equivalente uniformemente distribuída no vão.

$$
p_{b}=\varphi_{1} \cdot g+\varphi_{2} \cdot q
$$

Recomenda-se que toda ação permanente seja balanceada $\left(\varphi_{1}=1\right)$ e, se a ação variável não é significativa $\left(q \leq 3 \mathrm{kN} / \mathrm{m}^{2}\right), \varphi_{2}$ assume valores da ordem de 0,1 .

Para o traçado dos cabos adotam-se, inicialmente, as flechas máximas, respeitando o cobrimento adotado, a fim de obter a menor força de protensão. Com a geometria do cabo e a carga a ser balanceada, aplicam-se as expressões 6.1 e 6.2, determinando assim a força de protensão em cada tramo. Adota-se para cada cabo o maior valor de protensão necessária e corrigem-se os pontos de passagem dos cabos nos demais vãos, de modo a compensar a carga 
prevista. A armadura de protensão é determinada dividindo-se a força de protensão necessária pela tensão máxima que pode ser aplicada em cada cabo.

A parcela de carga balanceada não gera esforços de flexão, de modo que a laje fica submetida apenas a uma compressão uniforme, dada pela componente horizontal da força de protensão na ancoragem. Os esforços de flexão oriundos do carregamento não balanceado podem ser determinados pelos processos habituais da resistência dos materiais, expressão 6.4.

$$
\sigma= \pm \frac{\Delta M}{W}-\frac{P}{A}
$$

$\Delta \mathrm{M}$ : momento decorrente da carga não balanceada;

W: módulo de resistência à flexão;

$P$ : força de protensão;

A: área da seção transversal.

\subsubsection{Processo construtivo}

Segundo AALAMI (1994), alguns cuidados devem ser tomados nesse sistema construtivo:

- Usualmente os cabos são colocados antes da armadura passiva e dos condutos de instalação;

- Verificar se as elevações e a forma (parábola, circunferência e reta) dos cabos estão corretas;

- Verificar se os cabos têm excessiva deslocabilidade horizontal;

- Verificar se as ancoragens estão seguramente presas nas formas;

- Verificar a estabilidade dos cabos durante o lançamento do concreto;

- Verificar se a ancoragem está livre de graxa, sujeira e plástico;

- Verificar a elongação e depois cortar o cabo para permitir a colocação da proteção apropriada (figura 6.6). 


\subsubsection{Exemplo de utilização}

Um exemplo de aplicação das monocordoalhas engraxadas é o edifício late (figuras 6.5 a 6.8), que se trata de um flat com vinte pavimentos. Nesse edifício foram usadas vigas-faixa protendidas embutidas na laje.

O edifício late foi construído pela Construtora Reata (1998) em Fortaleza/CE. O projeto estrutural foi desenvolvido pelo engenheiro Hélder Martins e o serviço de protensão realizado pela Impacto Engenharia.

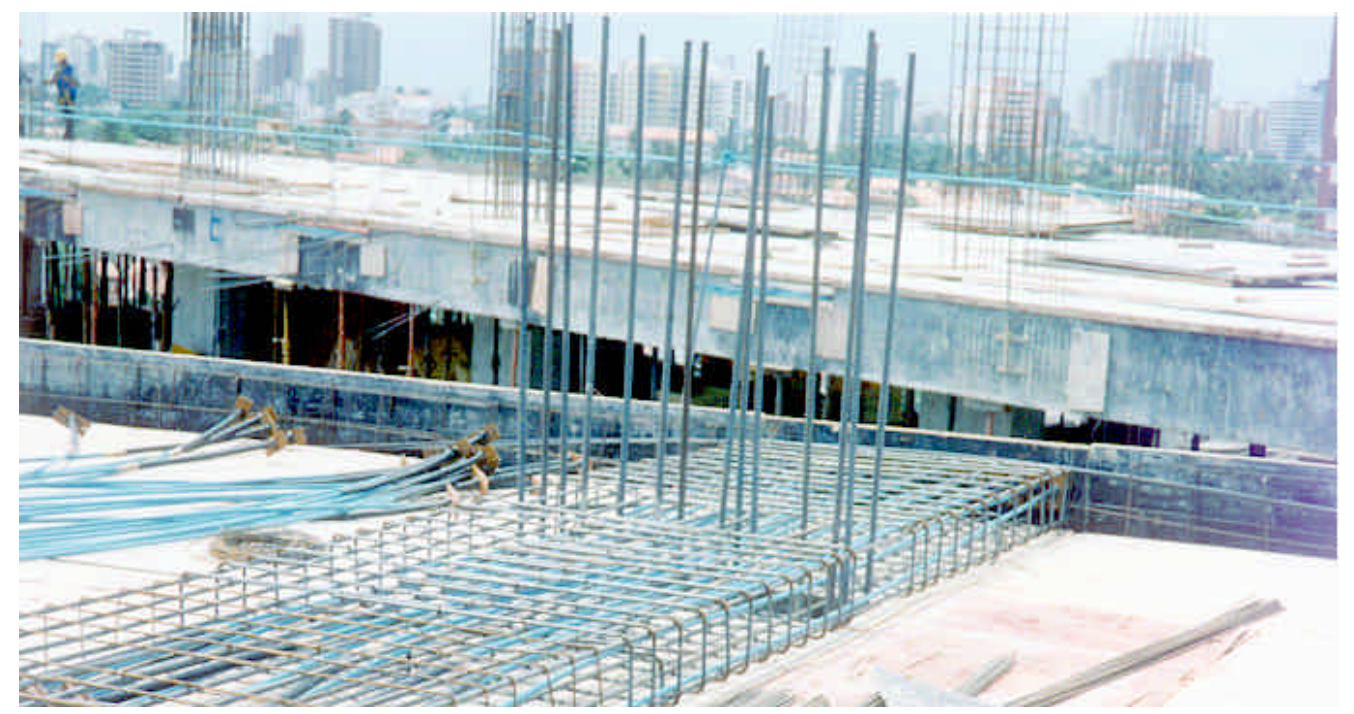

FIG. 6.5 - Armadura da viga-faixa protendida (Edifício late).

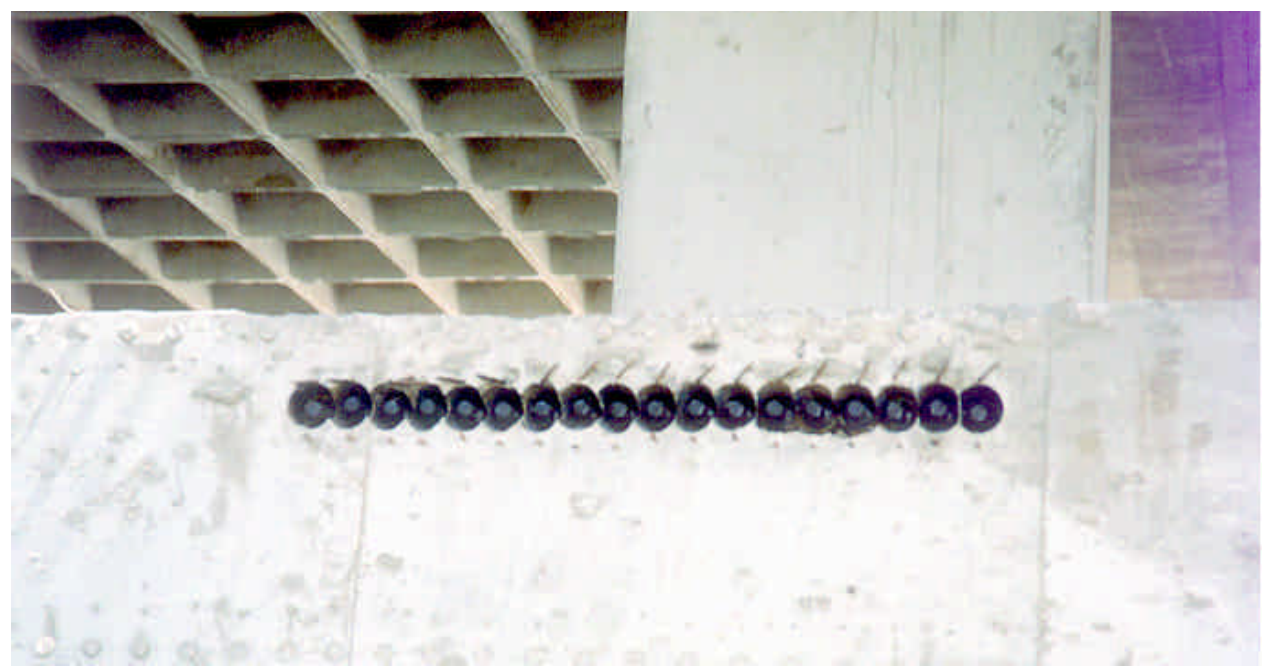

Fig. 6.6 - Proteção da ancoragem ativa pós protensão (Edifício late). 


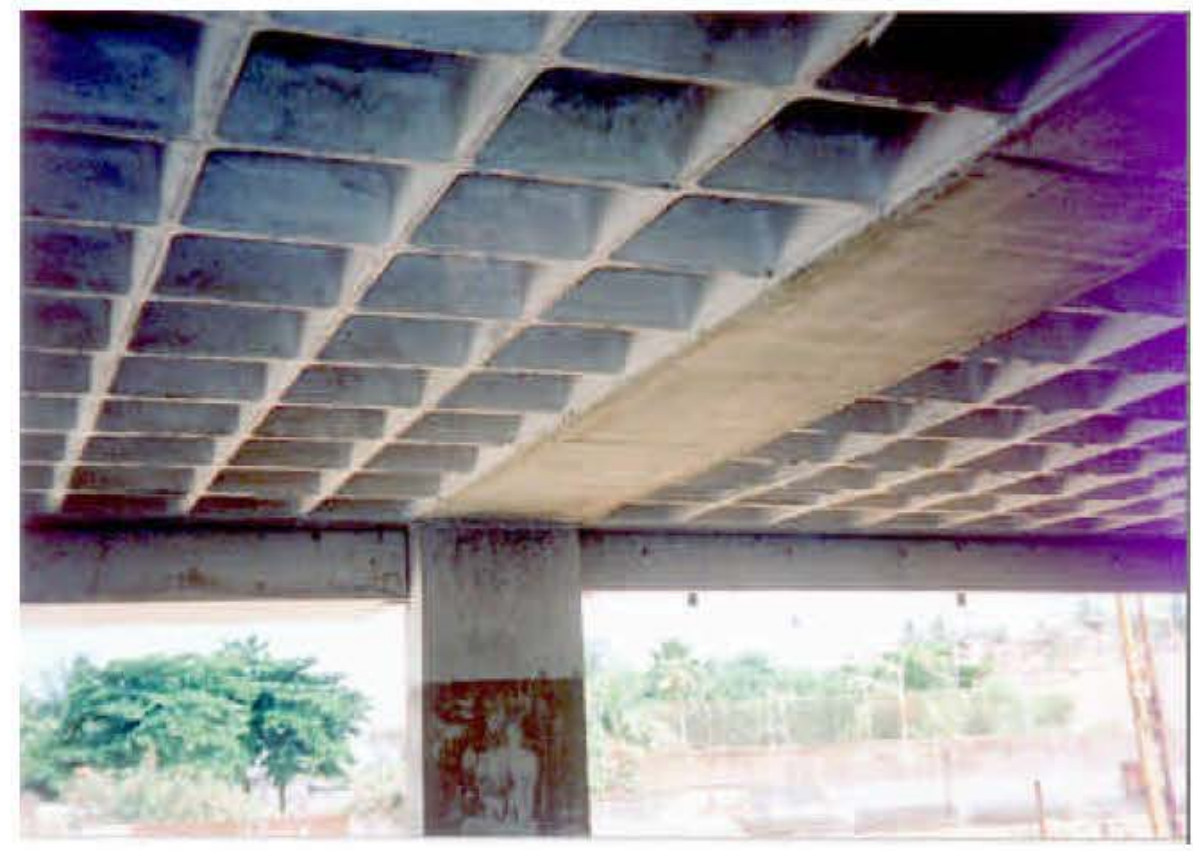

FIG. 6.7 - Viga-faixa (Edifício late).

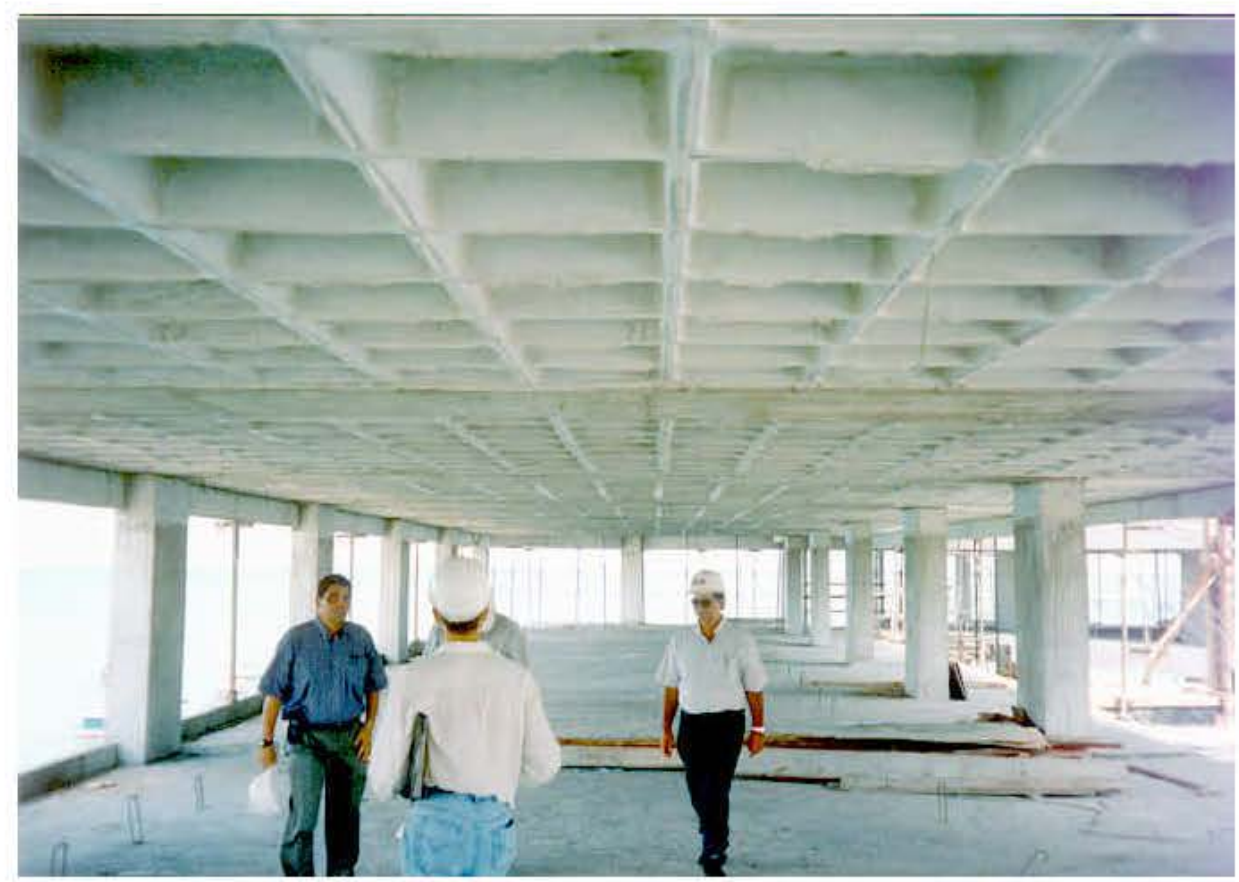

FIG. 6.8 - Característica de laje lisa (Edifício late). 


\subsection{ALTERNATIVA ADOTADA}

Nessa opção será utilizada a protensão com monocordoalhas engraxadas, que se apresenta como uma excelente opção para edifícios, por sua praticidade e simplicidade. Esse sistema estrutural é bastante recente no Brasil, mas já apresenta eficiência comprovada nos Estados Unidos.

Várias alternativas poderiam ser adotadas, baseadas no emprego das monocordoalhas engraxadas, dentre elas: laje lisa protendida e estrutura convencional com lajes ou com vigas protendidas. Ao se analisar a arquitetura do edifício-exemplo optou-se pela utilização de vigas-faixa protendidas embutidas na laje (figura 6.9), mesma solução do edifício late.

As lajes serão nervuradas e será utilizado o mesmo caixote da figura 5.1; esse caixote mais alto foi utilizado não por necessidade das lajes mas para aumentar a inércia das vigas que terão a mesma altura das lajes. Pode-se citar como vantagens desse sistema:

- pavimento não apresenta recorte pelo fato de as vigas serem embutidas, ou seja, tem características de laje lisa (figura 6.8);

- ausência de pilares internos, o que garante grande flexibilidade na variação da paginação dos pavimentos e liberdade maior para definição dos espaços internos do que a opção do capítulo 5;

- apresenta um menor número de pilares e de fundações;

- facilidade no desenrolamento das cordoalhas e no transporte e no armazenamento dos rolos de cordoalhas;

- nichos plásticos especiais mais fáceis de instalar e de retirar da forma para a protensão;

- operação de protensão extremamente rápida, aproximadamente dez segundos por cabo;

- não utiliza bainha metálica, que representa uma redução no custo do material e da mão-de-obra de execução;

Nessa alternativa a resistência do concreto será $f_{c k}=35 \mathrm{MPa}$ (vigas e pilares) e $\mathrm{f}_{\mathrm{ck}}=20 \mathrm{MPa}$ (lajes). 


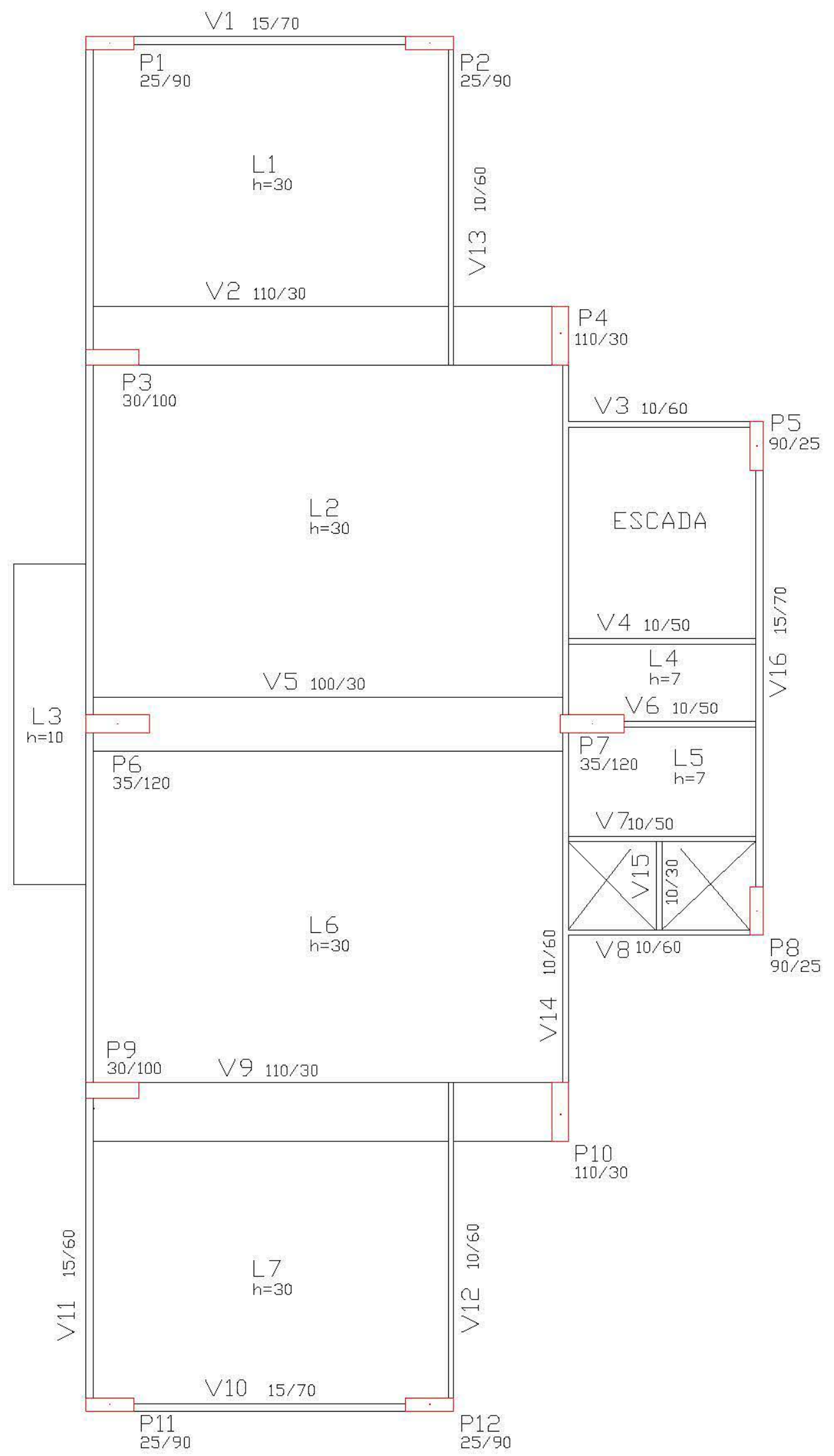

FIG. 6.9 - Forma da estrutura com vigas-faixa protendidas. 
Como as vigas-faixa são protendidas (figura 6.10), e peças protendidas precisam de uma resistência maior, elas terão o mesmo $f_{c k}$ das outras vigas e dos pilares, que é de 35MPa.

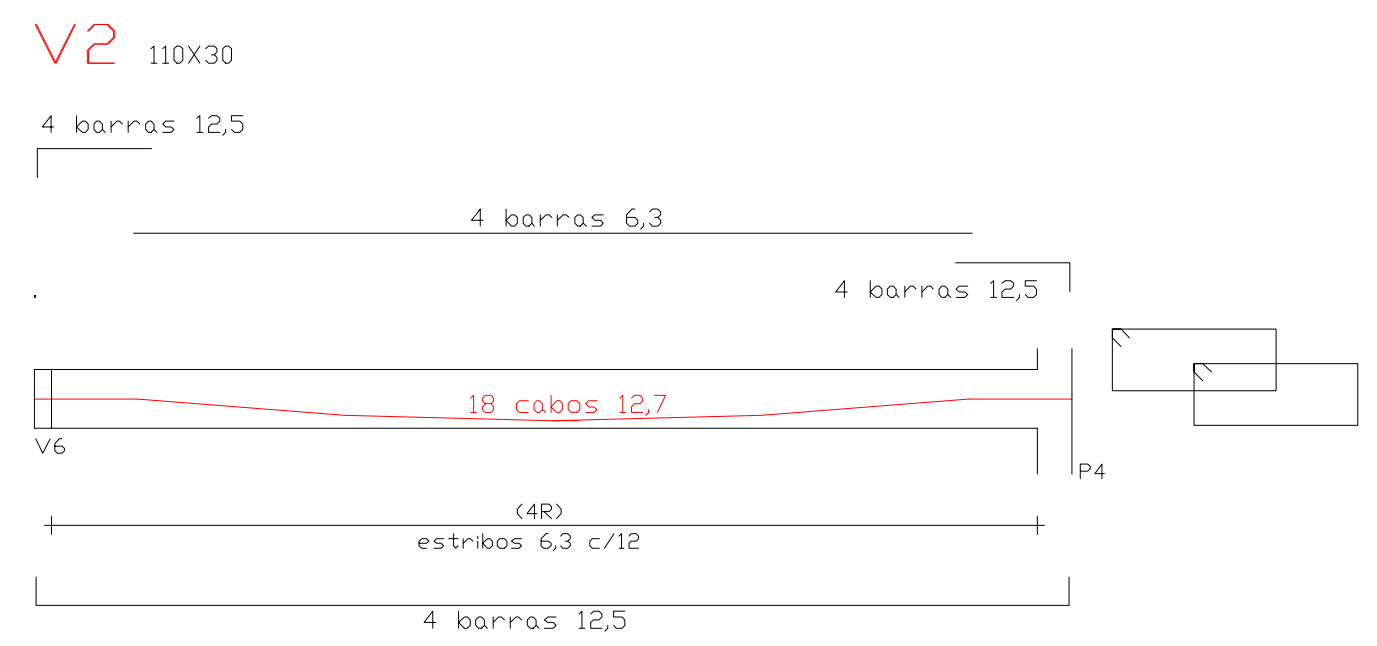

FIG. 6.10 - Detalhe da viga V8.

Para as vigas em questão, o grau de protensão adotado foi protensão limitada; existe protensão limitada quando se verificam duas condições:

a) para as combinações quase-permanentes de ações, previstas no projeto, é respeitado o estado limite de descompressão.

b) para as combinações freqüentes de ações, previstas no projeto, é respeitado o estado limite de formação de fissuras.

Nota-se que a estrutura apresenta rigidez deficiente aos esforços laterais, devido à falta de pórticos e ao baixo número de pilares. Por isso as dimensões das vigas externas foram aumentadas para fornecerem maior estabilidade ao edifício.

Os resultados relativos à estrutura com vigas-faixa protendidas estão indicados nas tabelas $6.1,6.2,6.3$ e 6.4 . 
TABELA 6.1 - Consumos de materiais.

\begin{tabular}{|c|c|c|c|}
\cline { 2 - 4 } \multicolumn{1}{c|}{} & $\begin{array}{c}\text { VOL. CONCRETO } \\
\left(\mathrm{m}^{3}\right)\end{array}$ & $\begin{array}{c}\text { AÇO } \\
(\mathrm{kg})\end{array}$ & $\begin{array}{c}\text { ÁREA DE FORMA } \\
\left(\mathrm{m}^{2}\right)\end{array}$ \\
\hline LAJES & 335,6 & $12.520,0$ & $3.963,2$ \\
\hline VIGAS & 284,2 & $32.234,0^{*}$ & $2.717,6$ \\
\hline PILARES & 195,2 & $23.210,0$ & $1.751,0$ \\
\hline TOTAL & 815,0 & $67.964,0$ & $8.431,8$ \\
\hline
\end{tabular}

*Esse item é referente apenas às armaduras passivas.

TABELA 6.2 - Índices.

\begin{tabular}{|c|c|c|c|}
\hline $\begin{array}{c}\text { ESP. MÉDIA } \\
(\mathrm{cm})\end{array}$ & $\begin{array}{c}\text { TAXA DE AÇO } \\
\left(\mathrm{kg} / \mathrm{m}^{3}\right)\end{array}$ & $\begin{array}{c}\text { TX. DE AÇO II } \\
\left(\mathrm{kg} / \mathrm{m}^{2}\right)\end{array}$ & $\begin{array}{c}\text { TX. FORMA } \\
\left(\mathrm{m}^{2} / \mathrm{m}^{2}\right)\end{array}$ \\
\hline 16,04 & 83,39 & 13,38 & 1,66 \\
\hline
\end{tabular}

TABELA 6.3 - Deslocamentos e parâmetros de instabilidade.

\begin{tabular}{|c|c|c|}
\cline { 2 - 3 } \multicolumn{1}{c|}{} & Direção $Y$ & Direção $X$ \\
\hline Deslocamento $(\mathrm{cm})$ & 10,32 & 4,11 \\
\hline$\gamma_{z}$ & 1,10 & 1,10 \\
\hline$\alpha$ & 0,78 & 0,77 \\
\hline
\end{tabular}

TABELA 6.4 - Outros dados.

\begin{tabular}{|c|c|}
\hline Caixotes por pavimento & 380 \\
\hline $\begin{array}{c}\text { Cabo protendido } \phi 12,7 \\
\text { (por pavimento) }\end{array}$ & 50 \\
\hline
\end{tabular}




\section{RESULTADOS E ANÁLISE DE CUSTOS}

\subsection{RESULTADOS}

Serão apresentados a seguir a tabela 7.1 e gráficos comparativos (figura 7.1) entre os consumos de todas as alternativas.
OP1: Estrutura convencional com lajes maciças
OP2: Estrutura convencional com lajes nervuradas (caixotes)
OP3: Estrutura convencional com lajes nervuradas (tijolos)
OP4: Estrutura convencional com lajes nervuradas (lajes pré-fabricadas)
OP5: Estrutura com laje lisa nervurada (caixotes)
OP6: Estrutura com laje lisa nervurada (tijolos)
OP7: Estrutura utilizando protensão

TABELA 7.1 - Consumos de materiais e índices.

\begin{tabular}{|c|c|c|c|c|c|c|c|}
\cline { 2 - 8 } \multicolumn{1}{c|}{} & $\begin{array}{c}\text { Volume } \\
\left(\mathrm{m}^{3}\right)\end{array}$ & $\begin{array}{c}\text { Aço } \\
(\mathrm{kg})\end{array}$ & $\begin{array}{c}\text { Forma } \\
\left(\mathrm{m}^{2}\right)\end{array}$ & $\begin{array}{c}\text { Esp. } \\
\text { média } \\
(\mathrm{cm})\end{array}$ & $\begin{array}{c}\text { Taxa de } \\
\text { aço } \\
\left(\mathrm{kg} / \mathrm{m}^{3}\right)\end{array}$ & $\begin{array}{c}\text { Tx. de } \\
\text { aço II } \\
\left(\mathrm{kg} / \mathrm{m}^{2}\right)\end{array}$ & $\begin{array}{c}\text { Tx. de } \\
\text { forma } \\
\left(\mathrm{m}^{2} / \mathrm{m}^{2}\right)\end{array}$ \\
\hline OP1 & $\begin{array}{c}817,4 \\
(1)\end{array}$ & $\begin{array}{c}76.554 \\
(1)\end{array}$ & $\begin{array}{c}9.641,6 \\
(1)\end{array}$ & 16,09 & 93,66 & 15,07 & 1,90 \\
\hline OP2 & $\begin{array}{c}724,2 \\
(-11,4 \%)\end{array}$ & $\begin{array}{c}64.431 \\
(-15,8 \%)\end{array}$ & $\begin{array}{c}8.973,2 \\
(-6,9 \%)\end{array}$ & 14,25 & 88,84 & 12,67 & 1,77 \\
\hline OP3 & $\begin{array}{c}750,6 \\
(-8,2 \%)\end{array}$ & $\begin{array}{c}71.257 \\
(-6,9 \%)\end{array}$ & $\begin{array}{c}8.973,2 \\
(-6,9 \%)\end{array}$ & 14,78 & 94,93 & 14,03 & 1,77 \\
\hline OP4 & $\begin{array}{c}734,9 \\
(-10,1 \%)\end{array}$ & $\begin{array}{c}63.108 \\
(-17,6 \%)\end{array}$ & $\begin{array}{c}5.213,6 \\
(-45,9 \%)\end{array}$ & 14,46 & 85,88 & 12,42 & 1,03 \\
\hline OP5 & $\begin{array}{c}882,2 \\
(+7,9 \%)\end{array}$ & $\begin{array}{c}71.829 \\
(-6,2 \%)\end{array}$ & $\begin{array}{c}8.896,4 \\
(-7,7 \%)\end{array}$ & 17,38 & 81,36 & 13,86 & 1,76 \\
\hline OP6 & $\begin{array}{c}897,6 \\
(+9,8 \%)\end{array}$ & $\begin{array}{c}78.512 \\
(+2,6 \%)\end{array}$ & $\begin{array}{c}8.896,4 \\
(-7,7 \%)\end{array}$ & 17,67 & 87,47 & 15,21 & 1,76 \\
\hline OP7 & $\begin{array}{c}815,0 \\
(-0,3 \%)\end{array}$ & $\begin{array}{c}67.964 \\
(-11,2 \%)\end{array}$ & $\begin{array}{c}8.431,8 \\
(-12,5 \%)\end{array}$ & 16,04 & 83,39 & 13,38 & 1,66 \\
\hline
\end{tabular}


a) Volume de concreto $\left(\mathrm{m}^{3}\right)$

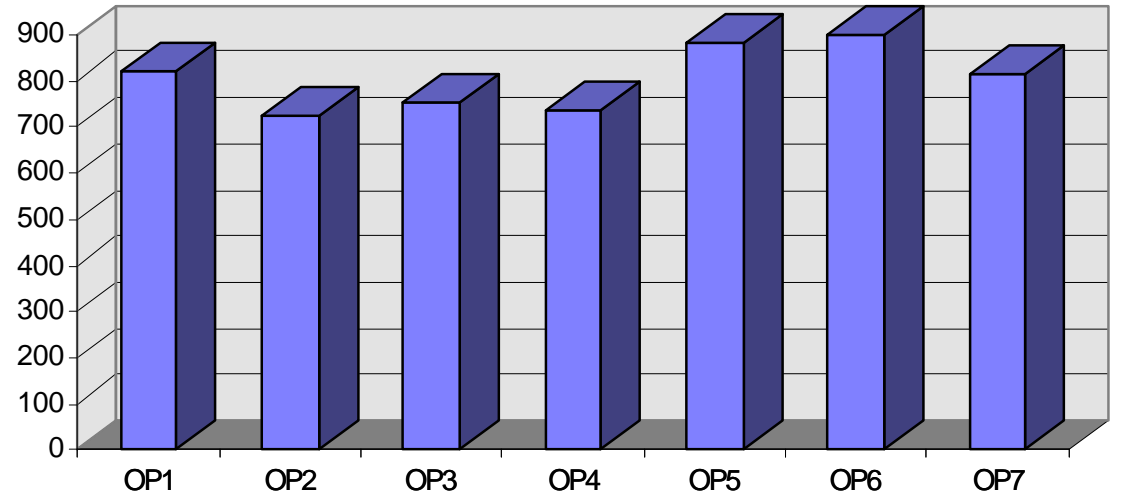

b) Consumo de aço $(\mathrm{kg})$

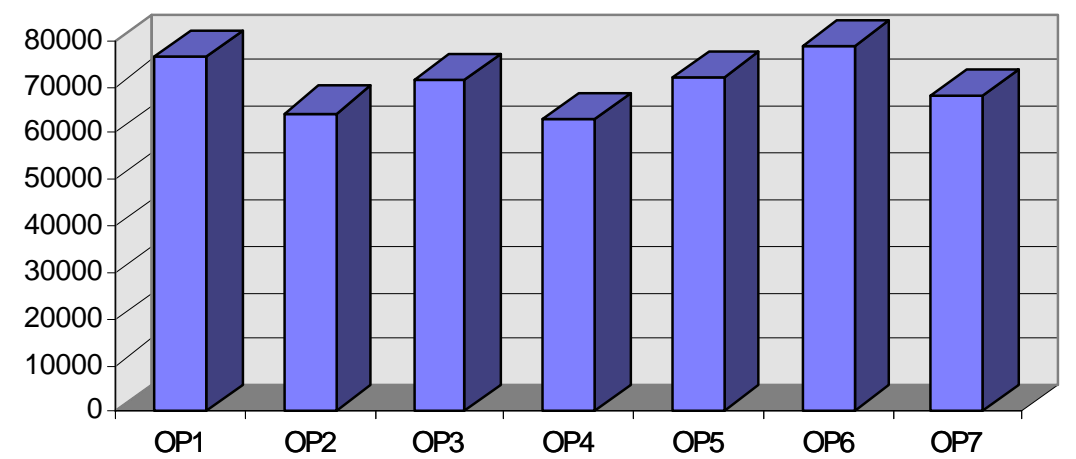

c) Consumo de forma $\left(\mathrm{m}^{2}\right)$

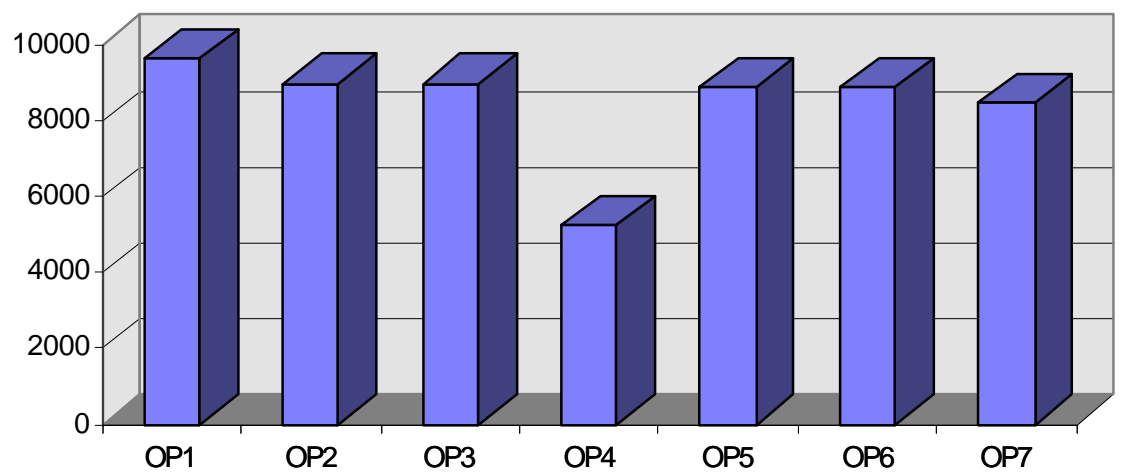

FIG. 7.1- Consumos de materiais. 
Verifica-se que a estrutura convencional com lajes maciças (OP1) apresenta um alto consumo de concreto, aço e forma; e uma forma muito recortada (muitas vigas), o que diminui a produtividade da obra.

As alternativas com lajes lisas (OP5 e OP6) apresentam alto consumo de aço e concreto, mas têm as vantagens de uma forma praticamente sem recortes (vigas só no contorno do pavimento).

As estruturas convencionais com lajes nervuradas (OP2, OP3 e OP4) têm o consumo mais baixo e pode-se dizer que a trabalhabilidade da forma é intermediária entre as alternativas anteriores (poucas vigas). Na opção com lajes pré-fabricadas (OP4) tem-se que levar em consideração o preço dessas peças.

A alternativa protendida com monocordoalhas engraxadas (OP7) apresenta um alto consumo de concreto, baixo consumo de aço e tem a forma sem recortes (vigas só no contorno do pavimento); tem-se de levar em consideração o preço da protensão (serviço e material).

Para aferir a viabilidade econômica de cada alternativa, deve-se fazer um orçamento criterioso, levando-se em consideração: consumo de materiais, equipamentos necessários, tempo de construção e mão-de-obra.

\subsection{ANÁLISE DE CUSTOS}

Para a composição dos custos, contou-se com a ajuda de uma renomada firma de execução de estruturas de concreto armado, com obras em vários estados: Ceará, São Paulo, Bahia e Maranhão. Pode-se ainda salientar a qualidade comprovada pelo recebimento do certificado da ISO 9002 (serviços). Essa firma construiu diversos edifícios, tendo assim experiência em todas as alternativas apresentadas nesta dissertação.

A metodologia adotada foi a pesquisa no banco de dados de estruturas já executadas, da referida firma, onde se calculou o preço unitário diferenciado para cada tipo de solução estrutural. Como o preço unitário foi avaliado a partir de obras já executadas, considerou-se implicitamente características como: mão-de-obra com encargos sociais, tempo de execução, equipamentos necessários e materiais consumidos.

De acordo com os dados obtidos, o serviço de concretagem (preparo, lançamento, adensamento e cura) não apresenta diferenças significativas 
de preço entre os elementos estruturais (laje, viga e pilar) e nem entre os diversos sistemas estruturais, por isso o preço unitário é o mesmo.

O serviço de armação (dobramento de barras e colocação nas formas) geralmente é empreitado em função da quantidade de aço (kg), por isso seu preço unitário também não varia entre os elementos estruturais e nem entre os sistemas estruturais.

Já o item formas (preparo e montagem) caracteriza bem a diferença existente entre os sistemas estruturais, variando seu preço unitário em função da facilidade de execução. De acordo com o exposto nos capítulos anteriores, admitiu-se que cada alternativa tem suas peculiaridades.

Nas alternativas que utilizaram caixotes (OP2, OP5 e OP7) o preço de depreciação dos mesmos foi considerado. Nas alternativas que utilizaram tijolos como material inerte (OP3 e OP6), também foi considerado o preço deles.

Foi considerado que todos os itens necessários para a execução das estruturas estavam disponíveis no local da obra.

$\mathrm{Na}$ alternativa OP4 no item preço dos pré-fabricados já estão inclusos: vigotas treliçadas, plaquetas e blocos de EPS.

$\mathrm{Na}$ alternativa OP7 no custo de protensão já estão inclusos os preços de:

- monocordoalhas engraxadas, ancoragens passivas e ativas;

- colocação dos cabos na forma e posicionamento das armaduras de protensão;

- colocação e fixação das ancoragens ativas nas formas;

- corte das pontas excedentes dos cabos nos nichos das ancoragens;

- pré-blocagem das ancoragens passivas;

- protensão propriamente dita, com controle do alongamento dos cabos.

Apresentam-se a seguir os custos relativos às diversas opções: 
7.2.1 ESTRUTURA CONVENCIONAL COM LAJES MACIÇAS

\section{CONCRETO}

\begin{tabular}{|l|r|r|r|}
\cline { 2 - 4 } \multicolumn{1}{c|}{} & Qte. $\left(\mathrm{m}^{3}\right)$ & P.Unit. $(\mathrm{R} \$)$ & P.Total $(\mathrm{R} \$)$ \\
\hline Lajes & 366,00 & 116,00 & $42.456,00$ \\
\hline Vigas & 244,60 & 126,00 & $30.819,60$ \\
\hline Pilares & 206,80 & 126,00 & $26.056,80$ \\
\hline Total & 817,40 & - & $99.332,40$ \\
\hline
\end{tabular}

AÇO

\begin{tabular}{|l|c|c|c|}
\cline { 2 - 4 } \multicolumn{1}{c|}{} & Qte. $(\mathrm{kg})$ & P.Unit. $(\mathrm{R} \$)$ & P.Tot. $(\mathrm{R} \$)$ \\
\hline Lajes & $18.389,00$ & 1,10 & $20.227,90$ \\
\hline Vigas & $36.888,00$ & 1,10 & $40.576,80$ \\
\hline Pilares & $21.277,00$ & 1,10 & $23.404,70$ \\
\hline Total & $76.554,00$ & & $84.209,40$ \\
\hline
\end{tabular}

FORMA

\begin{tabular}{|l|r|r|r|}
\cline { 2 - 4 } \multicolumn{1}{c|}{} & Qte. $\left(\mathrm{m}^{2}\right)$ & P.Unit. $(\mathrm{R} \$)$ & P.Tot. $(\mathrm{R} \$)$ \\
\hline Lajes & $4.234,60$ & 7,50 & $31.759,50$ \\
\hline Vigas & $3.535,00$ & 7,50 & $26.512,50$ \\
\hline Pilares & $1.872,00$ & 7,50 & $14.040,00$ \\
\hline Total & $9.641,60$ & - & $72.312,00$ \\
\hline
\end{tabular}

\begin{tabular}{|ll}
\hline CUSTO TOTAL (R\$) & $255.853,8$ \\
\hline
\end{tabular}

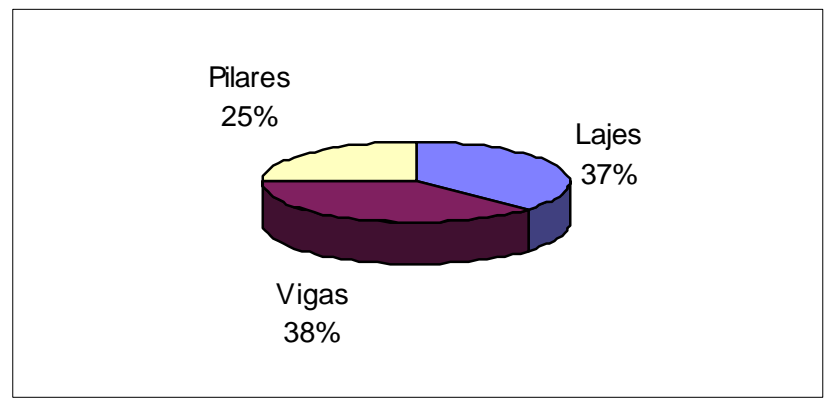

FIG. 7.2 - Custo percentual de cada elemento.

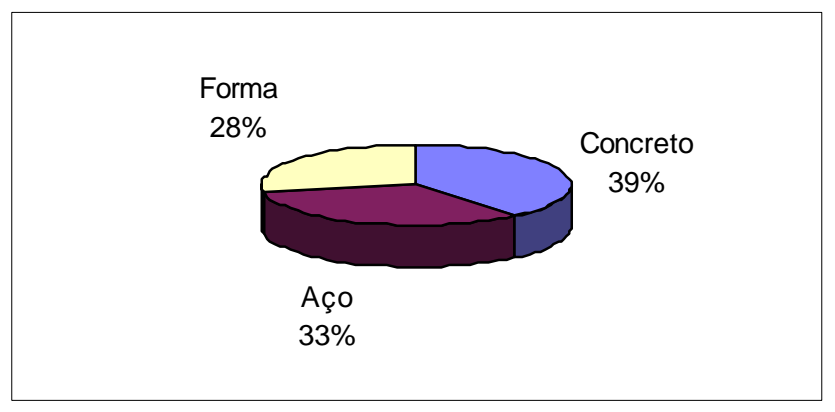

FIG. 7.3 - Custo percentual por etapa. 
7.2.2 EST. CONVENCIONAL COM LAJES NERVURADAS (CAIXOTES)

\section{CONCRETO}

\begin{tabular}{|l|r|r|r|}
\cline { 2 - 4 } \multicolumn{1}{c|}{} & Qte. $\left(\mathrm{m}^{3}\right)$ & P.Unit. (R\$) & P.Tot. $(\mathrm{R} \$)$ \\
\hline Lajes & 326,60 & 116,00 & $37.885,60$ \\
\hline Vigas & 190,80 & 126,00 & $24.040,80$ \\
\hline Pilares & 206,80 & 126,00 & $26.056,80$ \\
\hline Total & 724,20 & - & $87.983,20$ \\
\hline
\end{tabular}

AÇO

\begin{tabular}{|l|c|c|c|}
\cline { 2 - 4 } \multicolumn{1}{c|}{} & Qte. $(\mathrm{kg})$ & P.Unit. $(\mathrm{R} \$)$ & P.Tot. $(\mathrm{R} \$)$ \\
\hline Lajes & $14.704,00$ & 1,10 & $16.174,40$ \\
\hline Vigas & $30.253,00$ & 1,10 & $33.278,30$ \\
\hline Pilares & $19.384,00$ & 1,10 & $21.322,40$ \\
\hline Total & $64.341,00$ & - & $70.775,10$ \\
\hline
\end{tabular}

FORMA

\begin{tabular}{|l|r|r|r|}
\cline { 2 - 4 } \multicolumn{1}{c|}{} & \multicolumn{1}{c|}{ Qte. $\left(\mathrm{m}^{2}\right)$} & P.Unit. $(\mathrm{R} \$)$ & P.Tot. $(\mathrm{R} \$)$ \\
\hline Lajes & $4.327,00$ & 6,50 & $28.125,50$ \\
\hline Vigas & $2.773,80$ & 6,50 & $18.029,70$ \\
\hline Pilares & $1.872,00$ & 6,50 & $12.168,00$ \\
\hline Total & $8.972,80$ & - & $58.323,20$ \\
\hline
\end{tabular}

CUSTO TOTAL (R\$) 217.081,5

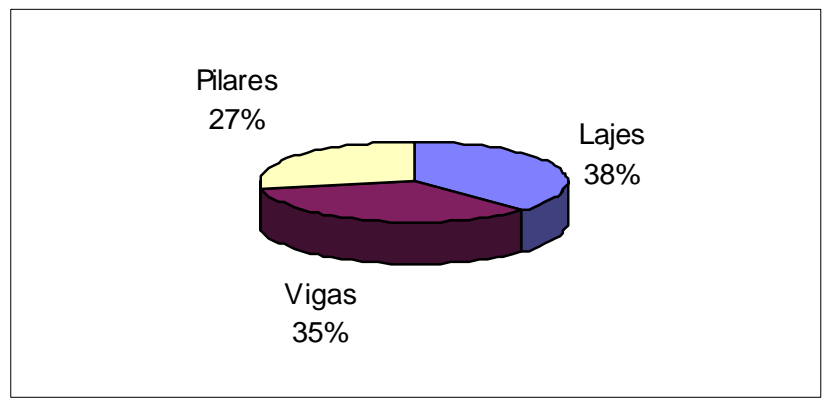

FIG. 7.4 - Custo percentual por elemento.

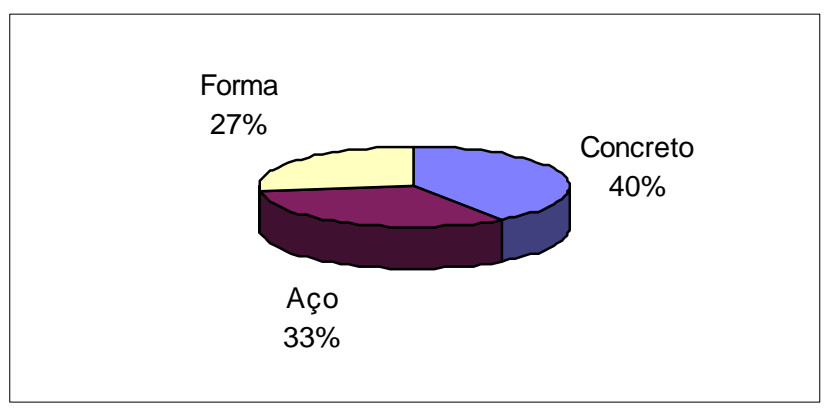

FIG. 7.5 - Custo percentual por etapa. 
7.2.3 EST. CONVENCIONAL COM LAJES NERVURADAS (TIJOLOS)

\section{CONCRETO}

\begin{tabular}{|l|r|r|r|}
\cline { 2 - 4 } \multicolumn{1}{c|}{} & Qte. $\left(\mathrm{m}^{3}\right)$ & P.Unit.(R\$) & P.Tot. (R\$) \\
\hline Lajes & 353,00 & 116,00 & $40.948,00$ \\
\hline Vigas & 190,80 & 126,00 & $24.040,80$ \\
\hline Pilares & 206,80 & 126,00 & $26.056,80$ \\
\hline Total & 750,60 & - & $91.045,60$ \\
\hline
\end{tabular}

AÇO

\begin{tabular}{|l|c|c|c|}
\cline { 2 - 4 } \multicolumn{1}{c|}{} & Qte. $(\mathrm{kg})$ & P.Unit.(R $\$)$ & P.Tot. $(\mathrm{R} \$)$ \\
\hline Lajes & $17.280,00$ & 1,10 & $19.008,00$ \\
\hline Vigas & $31.515,00$ & 1,10 & $34.666,50$ \\
\hline Pilares & $22.462,00$ & 1,10 & $24.708,20$ \\
\hline Total & $71.257,00$ & - & $78.382,70$ \\
\hline
\end{tabular}

FORMA

\begin{tabular}{|l|r|r|r|}
\cline { 2 - 4 } \multicolumn{1}{c|}{} & Qte. $\left(\mathrm{m}^{2}\right)$ & P.Unit. $(\mathrm{R} \$)$ & P.Tot. $(\mathrm{R} \$)$ \\
\hline Lajes & $4.327,00$ & 7,00 & $30.289,00$ \\
\hline Vigas & $2.773,80$ & 7,00 & $19.416,60$ \\
\hline Pilares & $1.872,00$ & 7,00 & $13.104,00$ \\
\hline Total & $8.972,80$ & - & $62.809,60$ \\
\hline
\end{tabular}

CUSTO TOTAL (R\$) 232.237,9

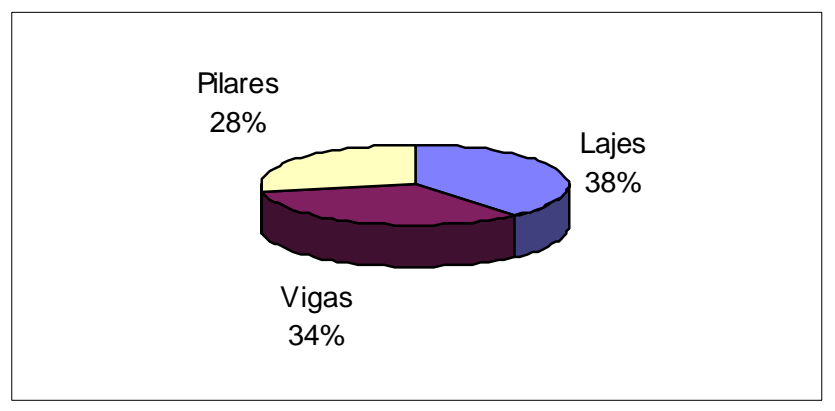

FIG. 7.6 - Custo percentual por elemento.

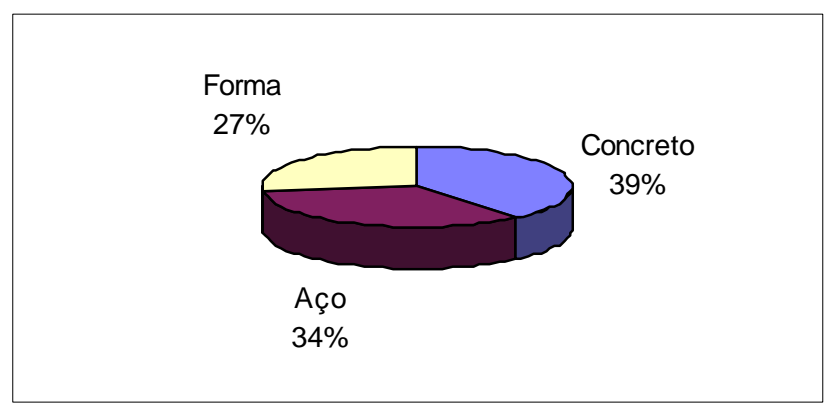

FIG. 7.7 - Custo percentual por etapa. 
7.2.4 EST. CONVENCIONAL COM LAJES NERVURADAS (PRÉ-FABRICADAS) CONCRETO

\begin{tabular}{|l|r|r|r|}
\cline { 2 - 4 } \multicolumn{1}{c|}{} & Qte. $\left(\mathrm{m}^{3}\right)$ & P.Unit. (R\$) & P.Tot. $(\mathrm{R} \$)$ \\
\hline Lajes & 337,28 & 116,00 & $39.124,48$ \\
\hline Vigas & 190,80 & 126,00 & $24.040,80$ \\
\hline Pilares & 206,80 & 126,00 & $26.056,80$ \\
\hline Total & 734,88 & - & $89.222,08$ \\
\hline
\end{tabular}

AÇO

\begin{tabular}{|l|c|c|c|}
\cline { 2 - 4 } \multicolumn{1}{c|}{} & Qte. $(\mathrm{kg})$ & P.Unit. $(\mathrm{R} \$)$ & P. Total $(\mathrm{R} \$)$ \\
\hline Lajes & $12.620,00$ & 1,10 & $13.882,00$ \\
\hline Vigas & $30.523,00$ & 1,10 & $33.575,30$ \\
\hline Pilares & $19.965,00$ & 1,10 & $21.961,50$ \\
\hline Total & $63.108,00$ & - & $69.418,80$ \\
\hline
\end{tabular}

FORMA

\begin{tabular}{|l|r|r|r|}
\cline { 2 - 4 } \multicolumn{1}{c|}{} & Qte. $\left(\mathrm{m}^{2}\right)$ & P.Unit. $(\mathrm{R} \$)$ & P.Tot. $(\mathrm{R} \$)$ \\
\hline Lajes & 567,00 & 6,50 & $3.685,50$ \\
\hline Vigas & $2.773,80$ & 6,50 & $18.029,70$ \\
\hline Pilares & $1.872,00$ & 6,50 & $12.168,00$ \\
\hline Total & $5.212,80$ & - & $33.883,20$ \\
\hline
\end{tabular}

PRÉ-FABRICADOS

\begin{tabular}{|c|c|c|}
\hline Qte. $\left(\mathrm{m}^{2}\right)$ & P.Unit. (R\$) & P.Tot. (R\$) \\
\hline $4.000,00$ & 8,90 & $35.600,00$ \\
\hline \multicolumn{3}{|c|}{ CUSTO TOTAL (R\$) } \\
\hline
\end{tabular}

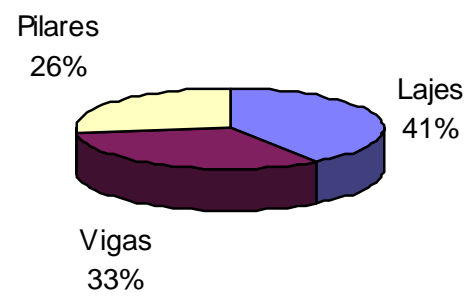

FIG. 7.8 - Custo percentual por elemento.

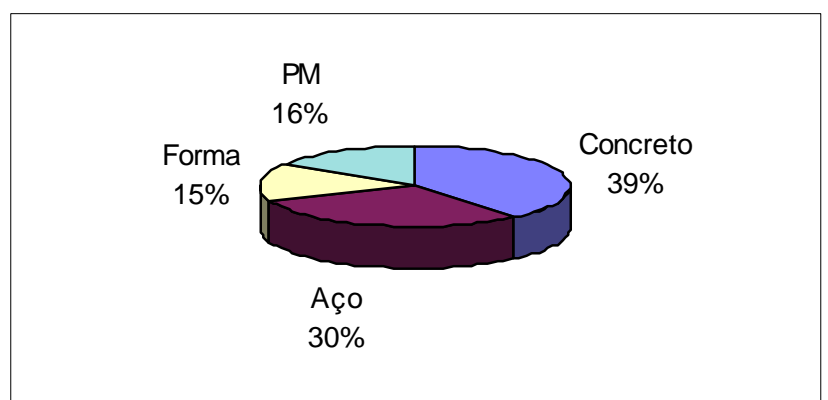

FIG. 7.9 - Custo percentual por etapa. 


\subsubsection{ESTRUTURA COM LAJE LISA NERVURADA (CAIXOTE)}

\section{CONCRETO}

\begin{tabular}{|l|r|r|r|}
\cline { 2 - 4 } \multicolumn{1}{c|}{} & Qte. $\left(\mathrm{m}^{3}\right)$ & P.Unit. $(\mathrm{R} \$)$ & P.Tot. $(\mathrm{R} \$)$ \\
\hline Lajes & 483,40 & 119,00 & $57.524,60$ \\
\hline Vigas & 139,00 & 126,00 & $17.514,00$ \\
\hline Pilares & 260,40 & 126,00 & $32.810,40$ \\
\hline Total & 882,80 & - & $107.849,00$ \\
\hline
\end{tabular}

AÇO

\begin{tabular}{|l|c|c|c|}
\cline { 2 - 4 } \multicolumn{1}{c|}{} & Qte. $(\mathrm{kg})$ & P.Unit. $(\mathrm{R} \$)$ & P.Tot. $(\mathrm{R} \$)$ \\
\hline Lajes & $20.112,00$ & 1,10 & $22.123,20$ \\
\hline Vigas & $26.860,00$ & 1,10 & $29.546,00$ \\
\hline Pilares & $24.857,00$ & 1,10 & $27.342,70$ \\
\hline Total & $71.829,00$ & - & $79.011,90$ \\
\hline
\end{tabular}

FORMA

\begin{tabular}{|l|r|r|r|}
\cline { 2 - 4 } \multicolumn{1}{c|}{} & \multicolumn{1}{c|}{ Qte. $\left(\mathrm{m}^{2}\right)$} & P.Unit. $(\mathrm{R} \$)$ & P.Tot. $(\mathrm{R} \$)$ \\
\hline Lajes & $4.415,00$ & 5,50 & $24.282,50$ \\
\hline Vigas & $2.200,40$ & 5,50 & $12.102,20$ \\
\hline Pilares & $2.281,00$ & 5,50 & $12.545,50$ \\
\hline Total & $8.896,40$ & - & $48.930,20$ \\
\hline
\end{tabular}

CUSTO TOTAL (R\$) 235.791,1

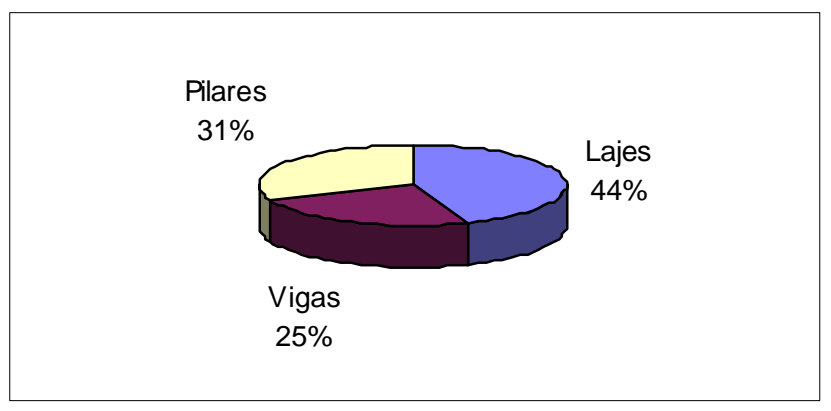

FIG. 7.10 - Custo percentual por elemento.

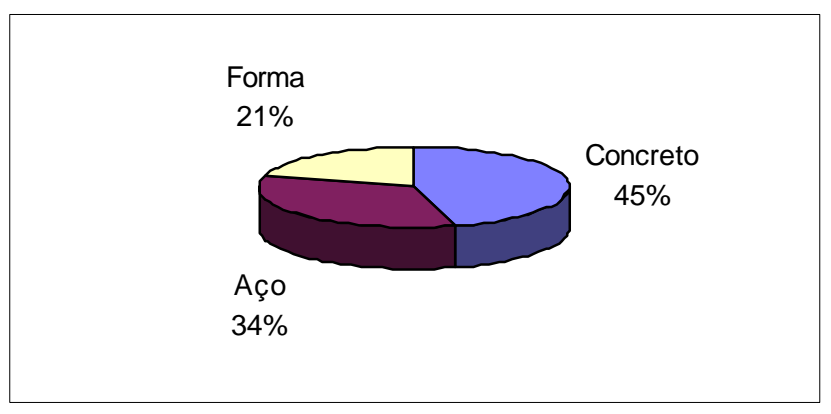

FIG. 7.11 - Custo percentual por etapa. 


\subsubsection{ESTRUTURA COM LAJE LISA NERVURADA (TIJOLOS)}

\section{CONCRETO}

\begin{tabular}{|l|r|r|r|}
\cline { 2 - 4 } \multicolumn{1}{c|}{} & Qte. $\left(\mathrm{m}^{3}\right)$ & P.Unit. $(\mathrm{R} \$)$ & P.Tot. $(\mathrm{R} \$)$ \\
\hline Lajes & 498,20 & 119,00 & $59.285,80$ \\
\hline Vigas & 139,00 & 126,00 & $17.514,00$ \\
\hline Pilares & 260,40 & 126,00 & $32.810,40$ \\
\hline Total & 897,60 & - & $109.610,20$ \\
\hline
\end{tabular}

AÇO

\begin{tabular}{|l|c|c|c|}
\cline { 2 - 4 } \multicolumn{1}{c|}{} & Qte. $(\mathrm{kg})$ & P.Unit. $(\mathrm{R} \$)$ & P.Tot. $(\mathrm{R} \$)$ \\
\hline Lajes & $28.408,00$ & 1,10 & $31.248,80$ \\
\hline Vigas & $27.186,00$ & 1,10 & $29.904,60$ \\
\hline Pilares & $22.918,00$ & 1,10 & $25.209,80$ \\
\hline Total & $78.512,00$ & - & $86.363,20$ \\
\hline
\end{tabular}

FORMA

\begin{tabular}{|l|r|r|r|}
\cline { 2 - 4 } \multicolumn{1}{c|}{} & Qte. $\left(\mathrm{m}^{2}\right)$ & P.Unit. $(\mathrm{R} \$)$ & P.Tot. $(\mathrm{R} \$)$ \\
\hline Lajes & $4.415,00$ & 6,00 & $26.490,00$ \\
\hline Vigas & $2.200,40$ & 6,00 & $13.202,40$ \\
\hline Pilares & $2.281,00$ & 6,00 & $13.686,00$ \\
\hline Total & $8.896,40$ & - & $53.378,40$ \\
\hline
\end{tabular}

CUSTO TOTAL (R\$) 249.351,8

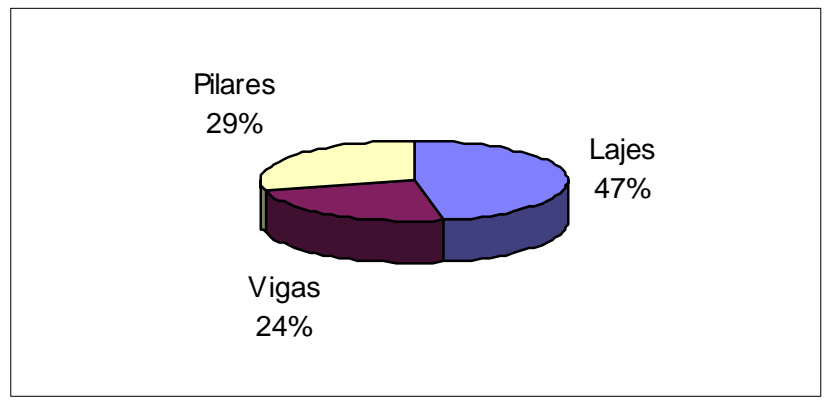

FIG. 7.12 - Custo percentual por elemento.

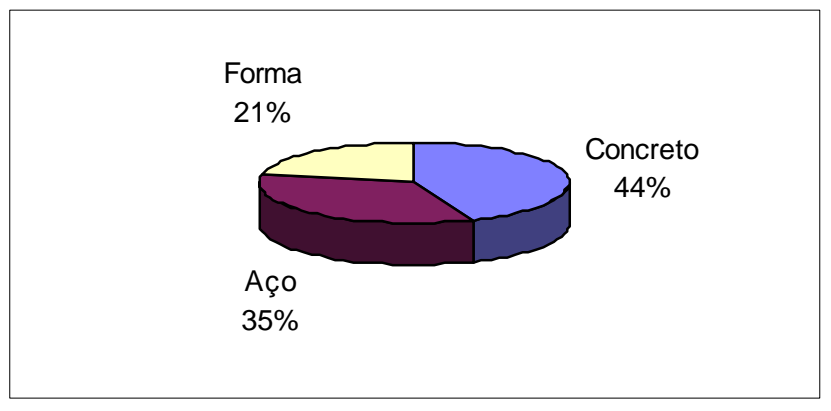

FIG. 7.13 - Custo percentual por etapa. 


\subsubsection{ESTRUTURA UTILIZANDO PROTENSÃO}

\section{CONCRETO}

\begin{tabular}{|l|r|r|r|}
\cline { 2 - 4 } \multicolumn{1}{c|}{} & Qte. $\left(\mathrm{m}^{3}\right)$ & P.Unit. $(\mathrm{R} \$)$ & P.Tot. $(\mathrm{R} \$)$ \\
\hline Lajes & 335,60 & 116,00 & $38.929,60$ \\
\hline Vigas & 284,20 & 126,00 & $35.809,20$ \\
\hline Pilares & 195,20 & 126,00 & $24.595,20$ \\
\hline Total & 815,00 & - & $99.334,00$ \\
\hline
\end{tabular}

AÇO

\begin{tabular}{|l|c|c|c|}
\cline { 2 - 4 } \multicolumn{1}{c|}{} & Qte. $(\mathrm{kg})$ & P.Unit. $(\mathrm{R} \$)$ & P.Tot. $(\mathrm{R} \$)$ \\
\hline Lajes & $12.520,00$ & 1,10 & $13.772,00$ \\
\hline Vigas & $32.234,00$ & 1,10 & $35.457,40$ \\
\hline Pilares & $23.210,00$ & 1,10 & $25.531,00$ \\
\hline Total & $67.964,00$ & - & $74.760,40$ \\
\hline
\end{tabular}

FORMA

\begin{tabular}{|l|r|r|r|}
\cline { 2 - 4 } \multicolumn{1}{c|}{} & \multicolumn{1}{c|}{ Qte. $\left(\mathrm{m}^{2}\right)$} & P.Unit. $(\mathrm{R} \$)$ & P.Tot. $(\mathrm{R} \$)$ \\
\hline Lajes & $3.963,20$ & 5,50 & $21.797,60$ \\
\hline Vigas & $2.717,60$ & 5,50 & $14.946,80$ \\
\hline Pilares & $1.751,00$ & 5,50 & $9.630,50$ \\
\hline Total & $8.431,80$ & - & $46.374,90$ \\
\hline
\end{tabular}

\section{CUSTO PROTENSÃO}

\begin{tabular}{|c|c|c|}
\hline Qte. (kg) & P.Unit. (R\$) & P.Tot. (R\$) \\
\hline $8.062,60$ & 3,86 & $31.121,64$ \\
\hline \multicolumn{2}{|c|}{ CUSTO TOTAL (R\$) } & $251.590,9$ \\
\hline
\end{tabular}

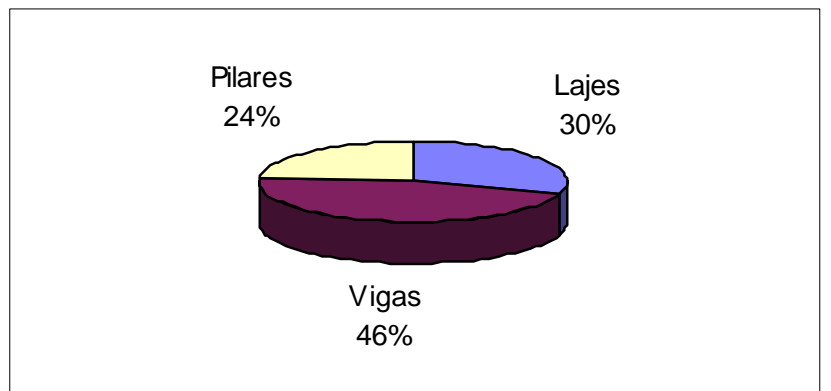

FIG. 7.14 - Custo percentual por elemento.

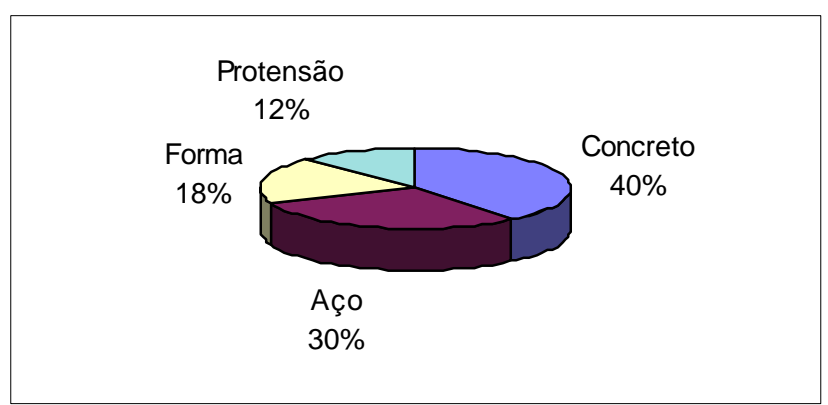

FIG. 7.15 - Custo percentual por etapa. 


\subsection{COMPARATIVO DE CUSTOS}

A tabela 7.2 e a figura 7.16 indicam os custos totais de todas as alternativas consideradas.

Tabela 7.2 - Tabela comparativa de custos (R\$).

\begin{tabular}{|c|c|c|c|c|c|c|}
\hline OP1 & OP2 & OP3 & OP4 & OP5 & OP6 & OP7 \\
\hline 255.853 & 217.081 & 232.237 & 228.124 & 235.791 & 249.351 & 251.590 \\
$(+17,9 \%)$ & $(1)$ & $(+7,0 \%)$ & $(+5,1 \%)$ & $(+8,6 \%)$ & $(+14,9 \%)$ & $(+15,9 \%)$ \\
\hline
\end{tabular}

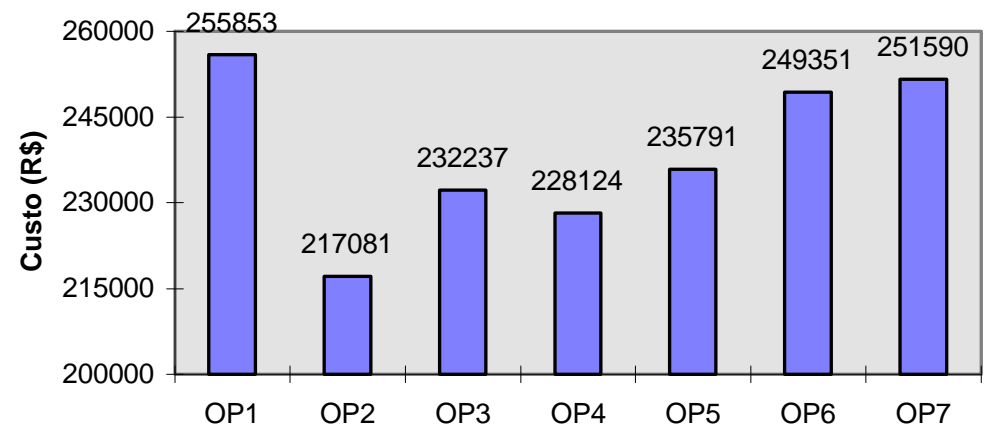

FIG. 7.16 - Custo global.

\subsection{VERIFICAÇÃO DE PARTE DOS RESULTADOS}

Um estudo semelhante foi feito por COSTA (1997), para um edifício comercial com vinte e cinco pavimentos e com uma área de $567 \mathrm{~m}^{2}$ por pavimento. De acordo com os consumos apresentados por ele, foram calculados os custos das estruturas, baseados nas planilhas deste capítulo. Esses custos serão apresentados na tabela 7.3.

As opções analisadas foram: estrutura convencional (equivalente à OP1, figura 7.17), lajes nervuradas com caixotes (equivalente à OP2, figura 7.18) e laje-cogumelo nervurada com caixote (equivalente à OP5, figura 7.19).

Verifica-se que a alternativa convencional com lajes nervuradas também apresenta o menor custo e os aumentos de custo das outras alternativas são similares aos apresentados na tabela 7.2. A estrutura convencional com lajes maciças teve o custo aumentado de $15 \%$ (enquanto na tabela 7.2 foi de $17,9 \%$ ) e a 
estrutura com laje lisa nervurada teve o custo aumentado de $5 \%$ (enquanto na tabela 7.2 foi de $8,6 \%)$.

Tabela 7.3 - Tabela comparativa de custos (R\$).

\begin{tabular}{|c|c|c|}
\hline OP1 & OP2 & OP5 \\
\hline 737.472 & 642.270 & 674.073 \\
$(+15,0 \%)$ & $(1)$ & $(+5,0 \%)$ \\
\hline
\end{tabular}




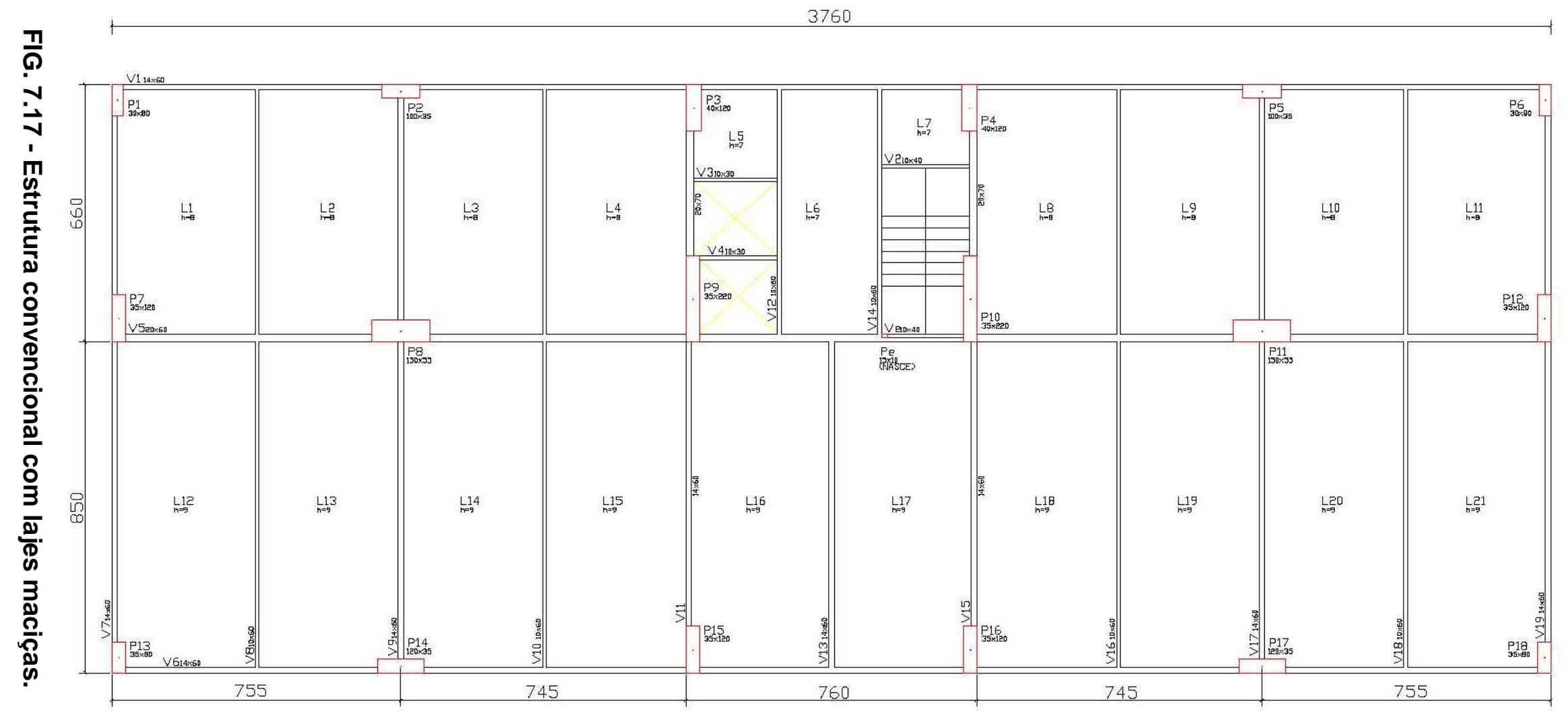




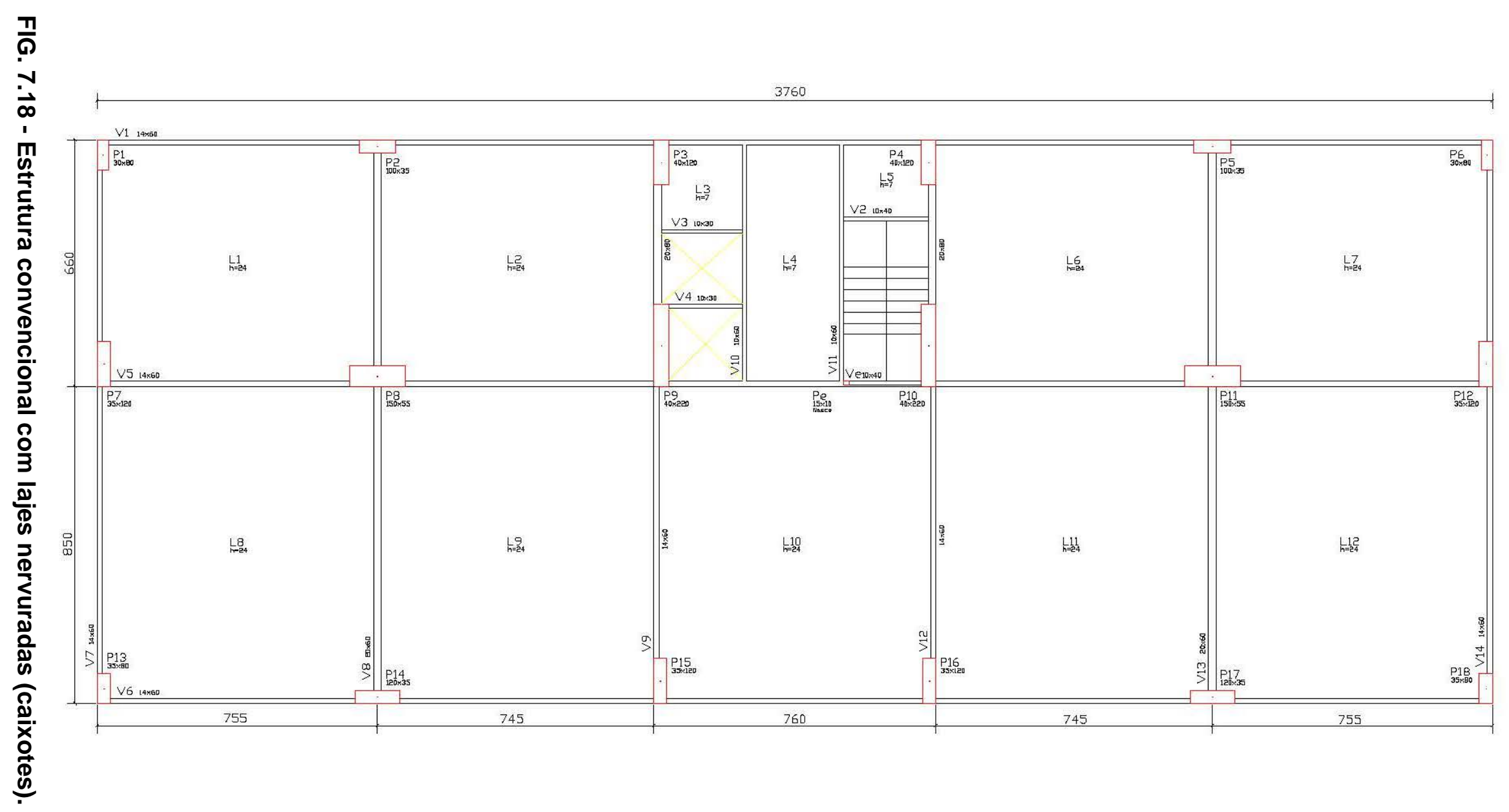




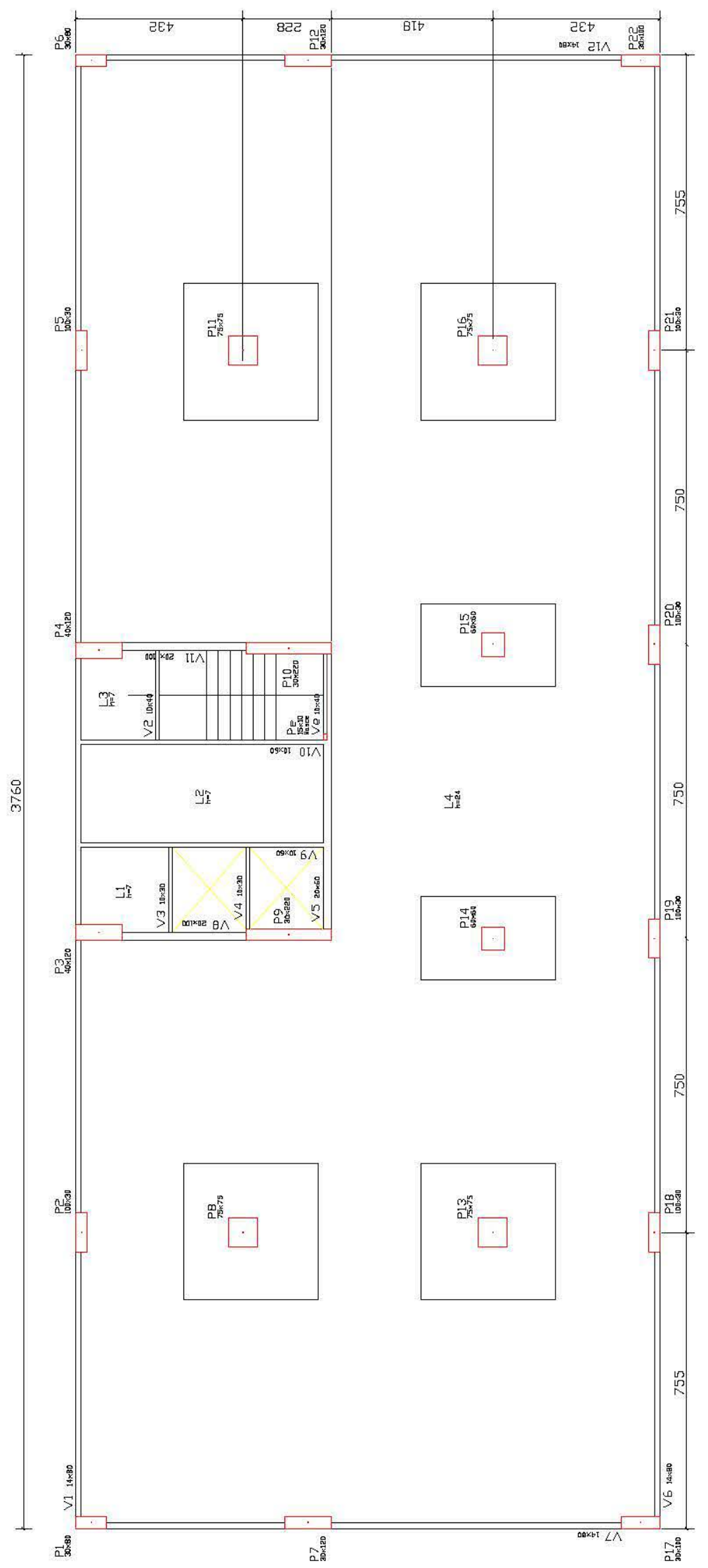

FIG. 7.19 - Estrutura com laje lisa nervurada (caixotes). 


\section{FUNDAÇÕES}

\subsection{INTRODUÇÃO}

De posse dos resultados indicados no capítulo anterior, restou a dúvida de como se comportariam as diferenças de custo, em termos percentuais, entre as alternativas com a inclusão das fundações. Esse questionamento surge devido às diferenças existentes entre os pesos totais das estruturas adotadas e da quantidade diferente de pilares entre as alternativas.

Então com o intuito de completar o estudo foram projetadas as fundações de todas as alternativas (figuras 8.1 a 8.7).

Conforme sugestão do Professor $\mathrm{AOKI}^{1}$ (1998), admitiu-se que o solo tinha uma tensão admissível de 0,35 MPa e que se indicavam fundações diretas sobre sapatas; as sapatas foram dimensionadas em função apenas das cargas verticais e foi utilizado $u m \mathrm{f}_{\mathrm{ck}}=35 \mathrm{MPa}$. Essas simplificações foram baseadas no fato do presente trabalho ser apenas um estudo comparativo.

\subsection{RESULTADOS}

Os consumos e os custos das fundações de cada alternativa serão apresentados a seguir.

\footnotetext{
${ }^{1}$ AOKI, N. (1998). (USP. Escola de Engenharia de São Carlos). Comunicação pessoal.
} 

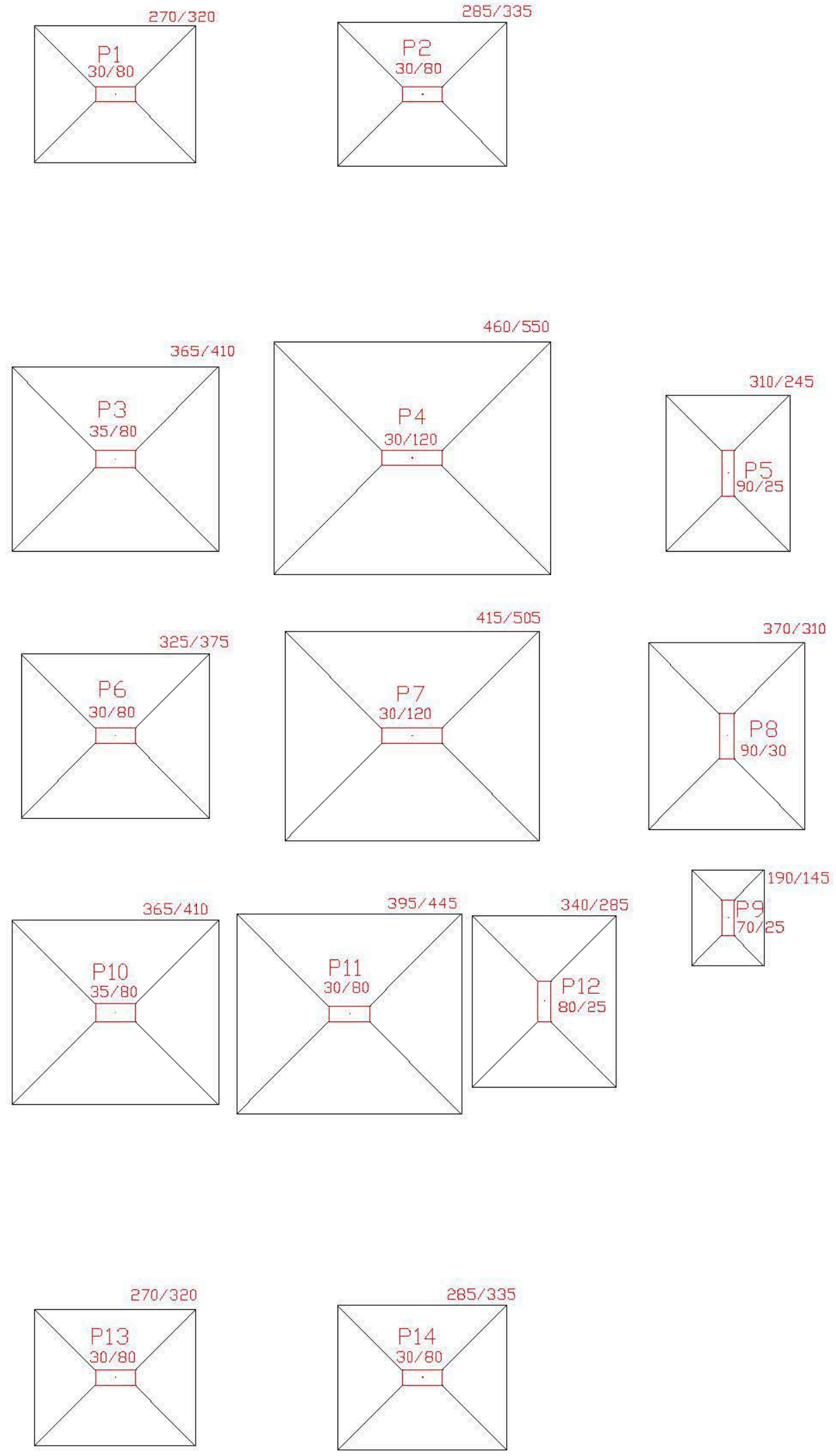

FIG. 8.1 - Estrutura convencional com lajes maciças. 

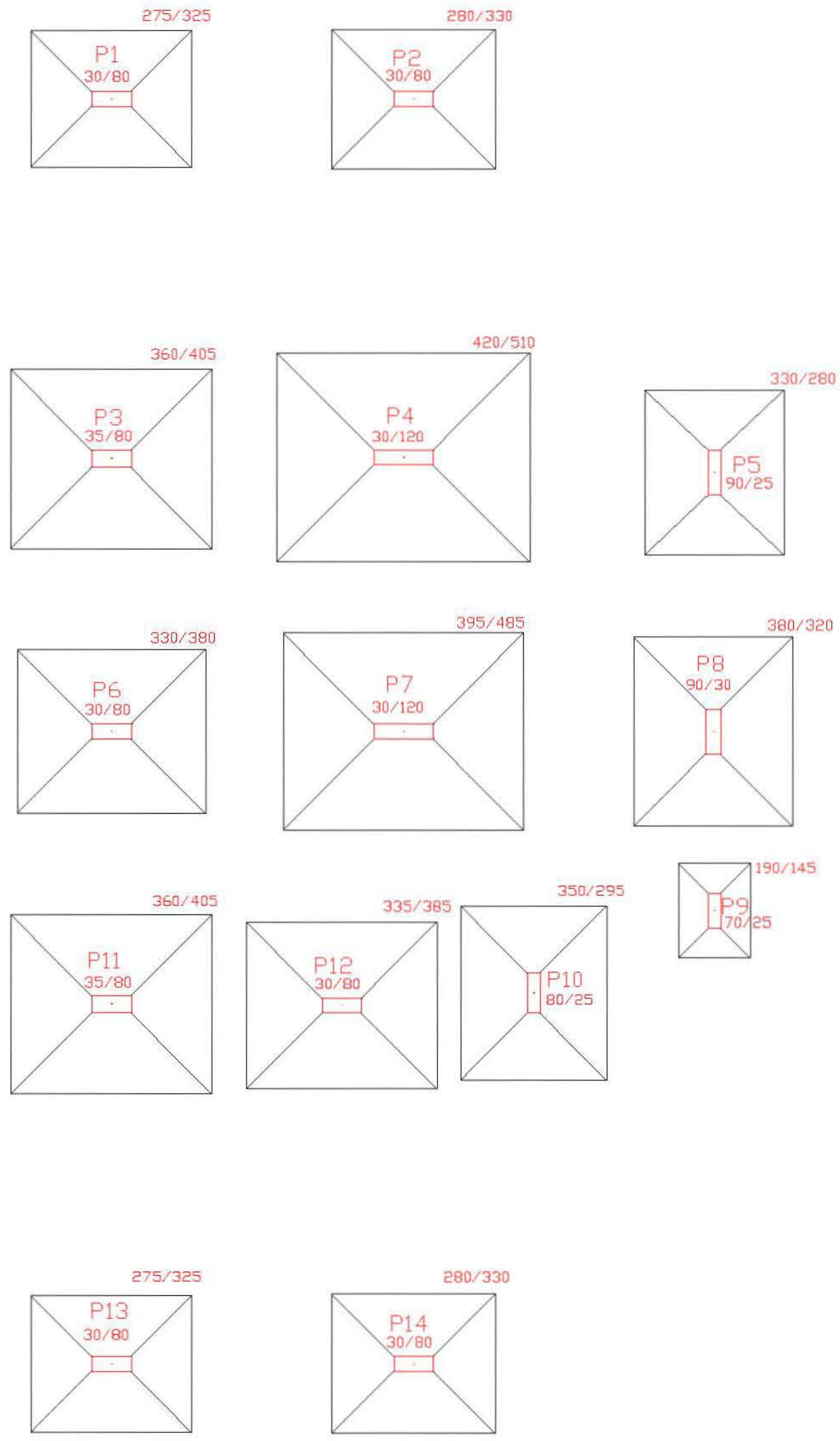

FIG. 8.2 - Estrutura convencional com lajes nervuradas (caixotes). 

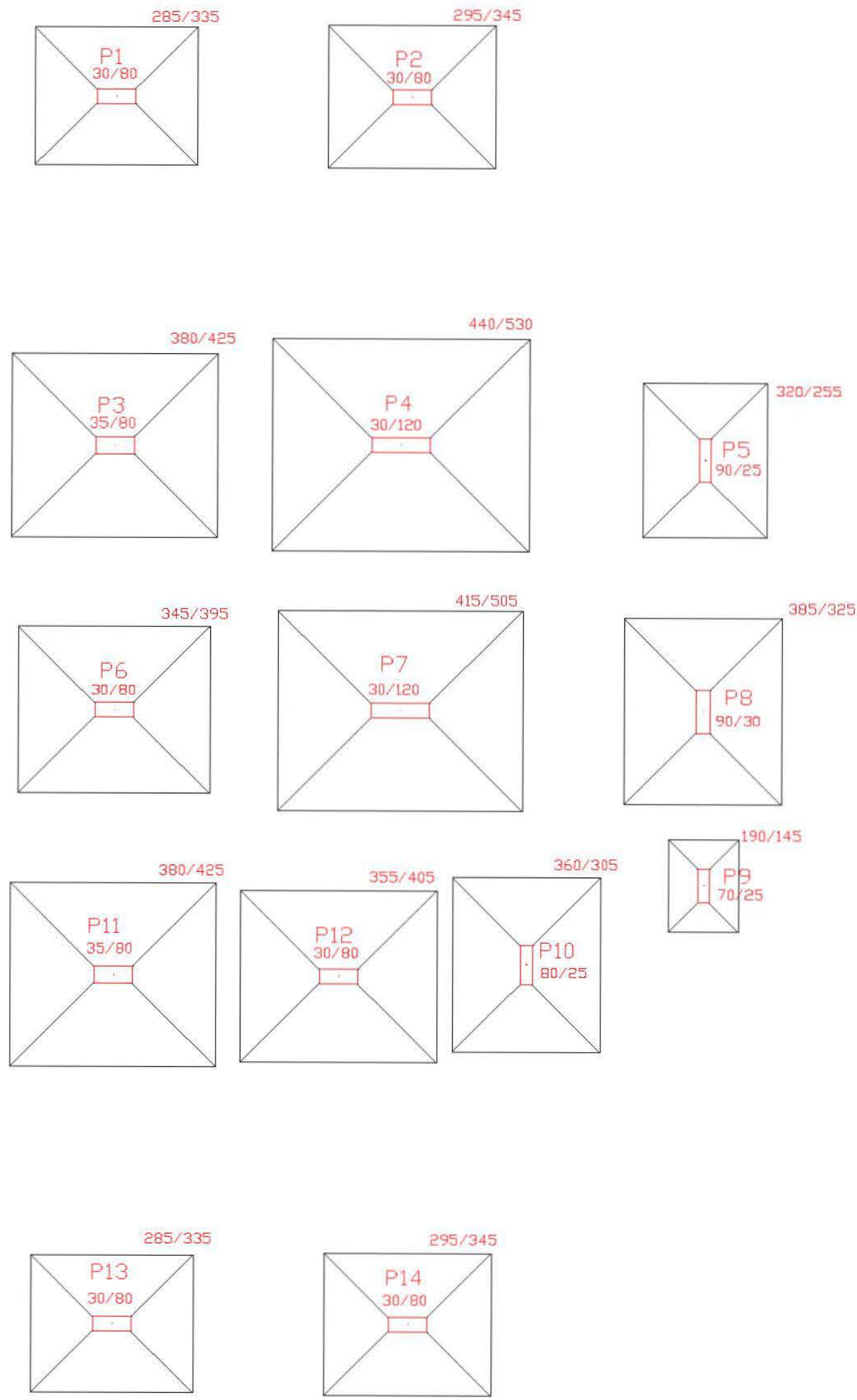

FIG. 8.3 - Estrutura convencional com lajes nervuradas (tijolos). 

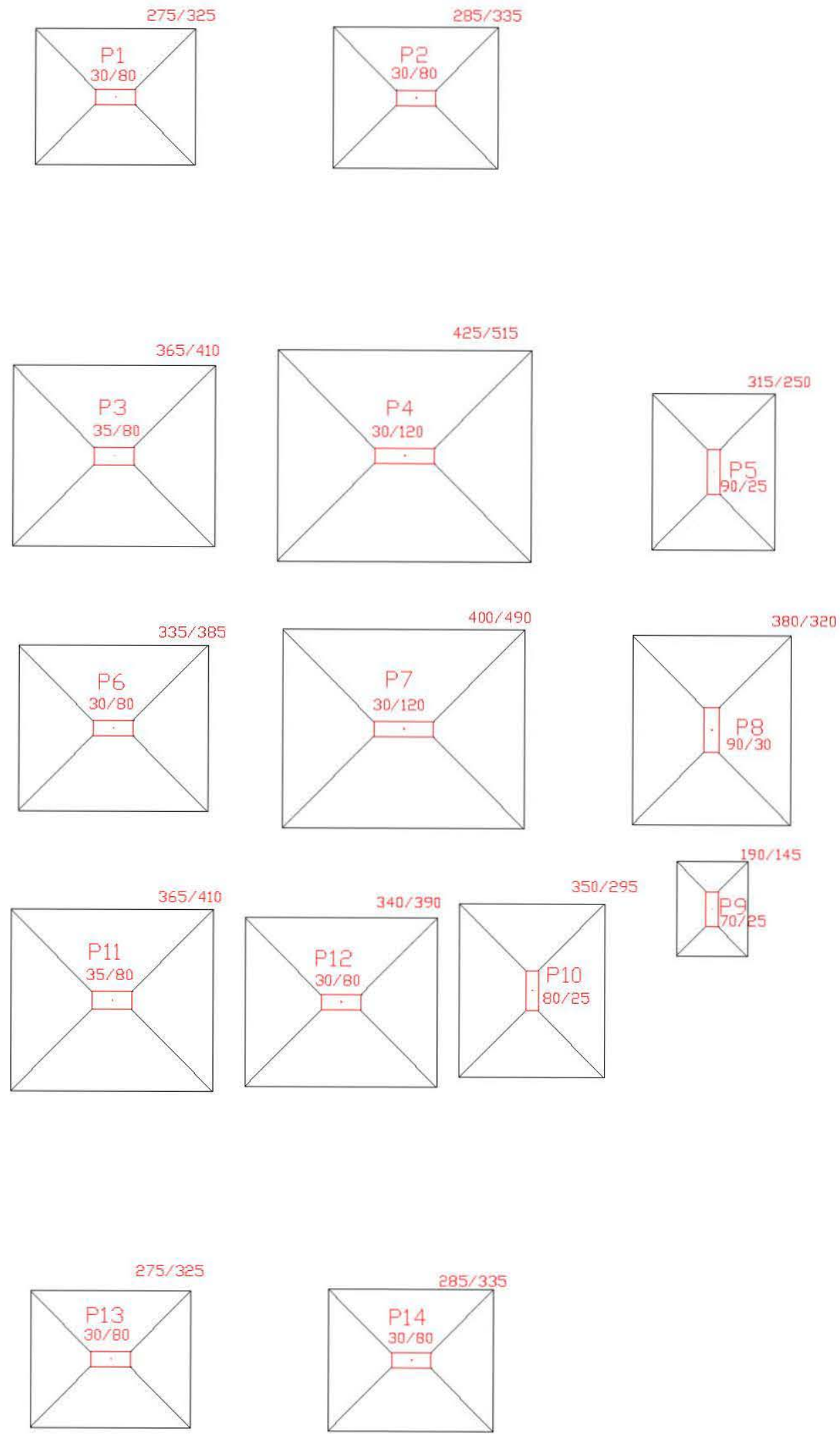

FIG. 8.4 - Estrutura convencional com lajes nervuradas (pré-moldadas). 

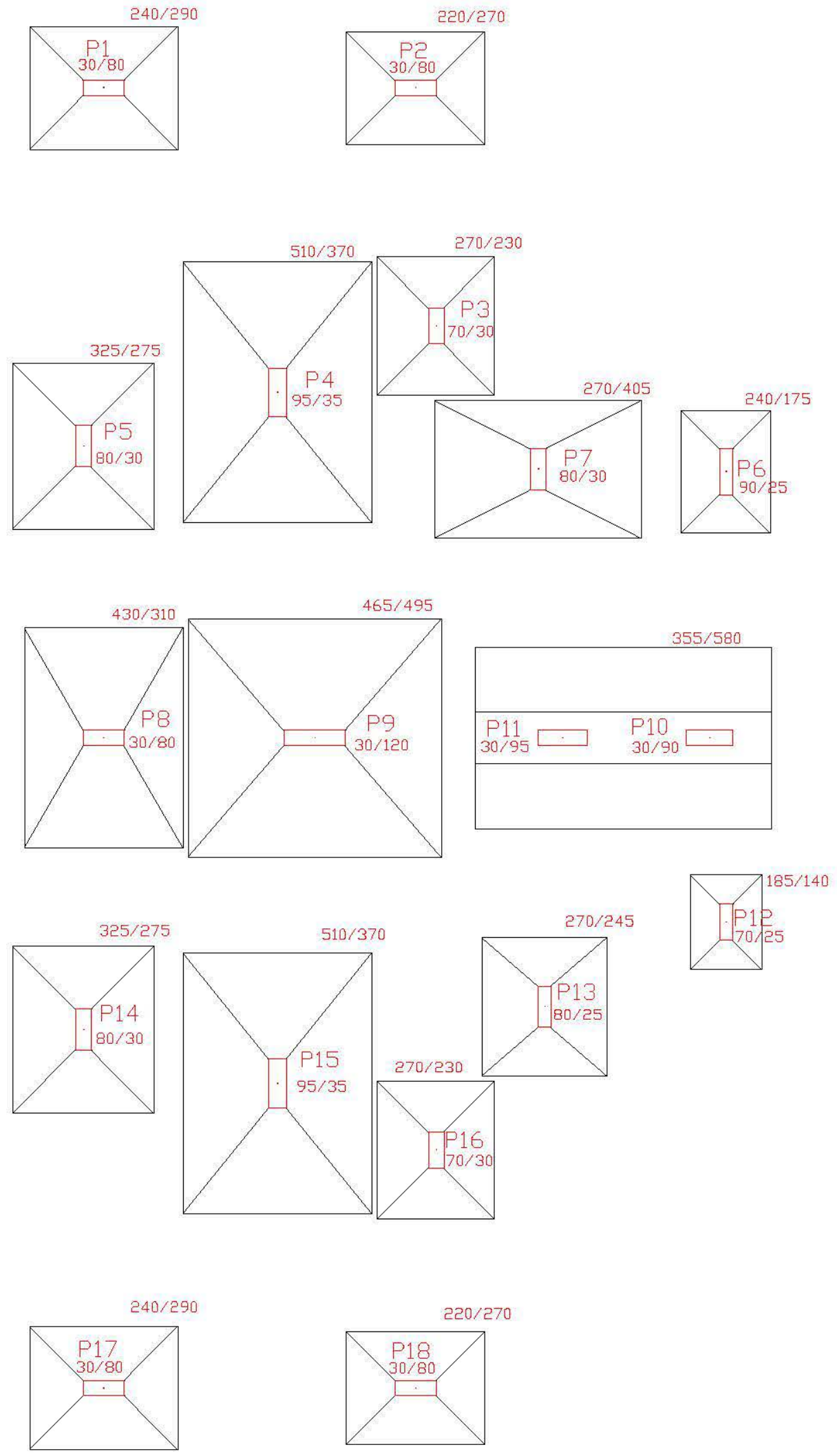

FIG. 8.5 - Estrutura com laje lisa (caixotes). 

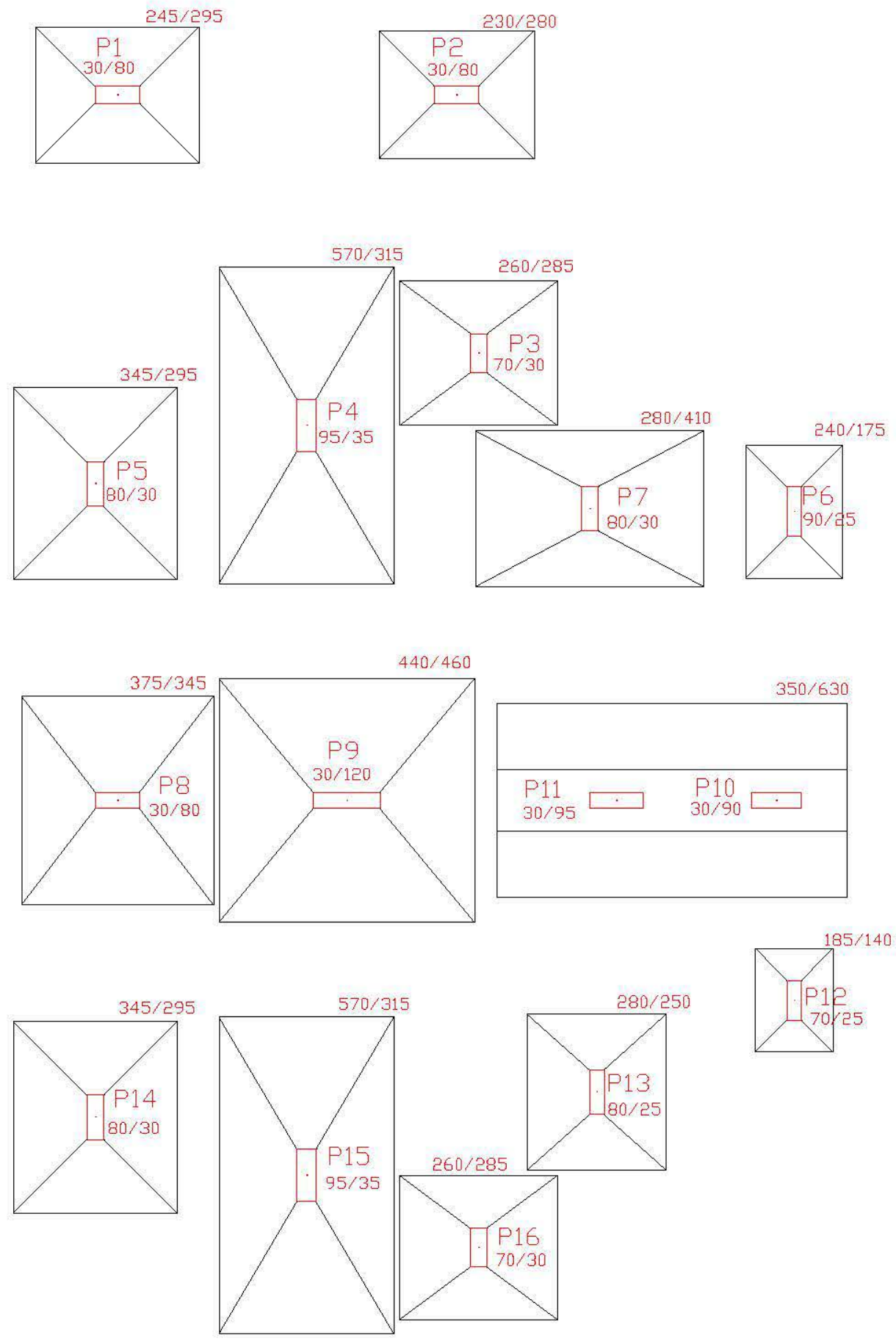

$245 / 295$

$230 / 280$
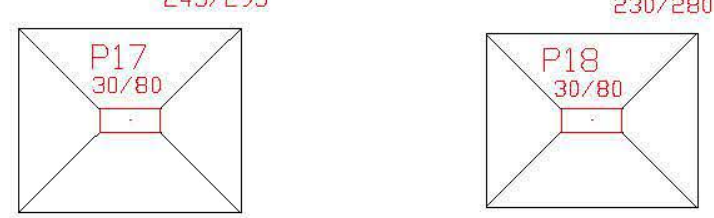

FIG. 8.6 - Estrutura com laje lisa (tijolos). 

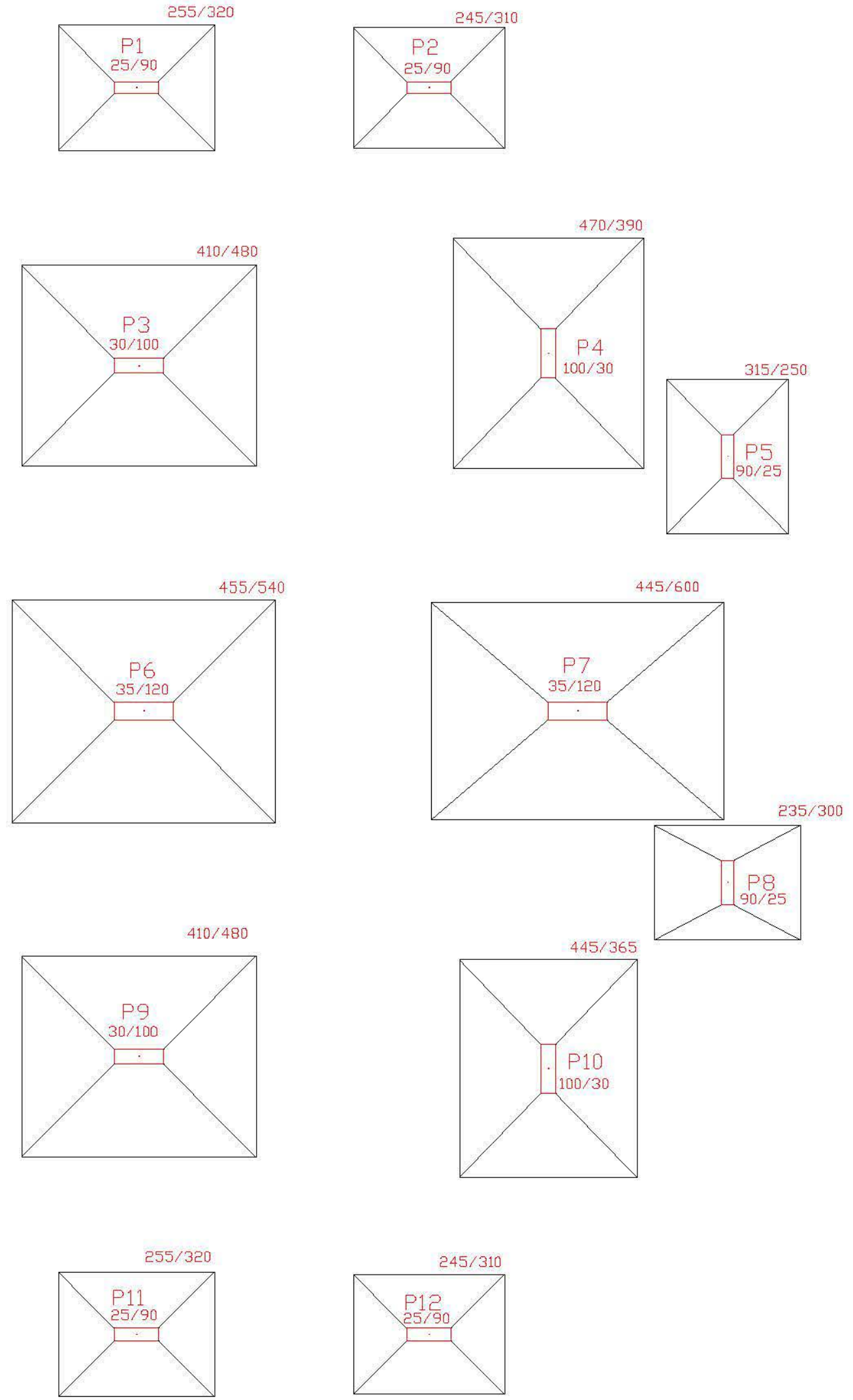

FIG. 8.7 - Estrutura utilizando protensão. 


\subsubsection{ESTRUTURA CONVENCIONAL COM LAJES MACIÇAS}

\section{FUNDAÇÕES}

\begin{tabular}{|l|c|c|c|}
\cline { 2 - 4 } \multicolumn{1}{c|}{} & Qte. & P.Unit. $(\mathrm{R} \$)$ & P.Total $(\mathrm{R} \$)$ \\
\hline Concreto $\left(\mathrm{m}^{3}\right)$ & 88,18 & 126,00 & $11.110,68$ \\
\hline Aço $(\mathrm{kg})$ & 6.225 & 1,10 & $6.847,50$ \\
\hline \multicolumn{2}{l}{} & Total & $17.958,18$ \\
\cline { 2 - 4 }
\end{tabular}

CUSTO TOTAL (R\$) 273.811,98

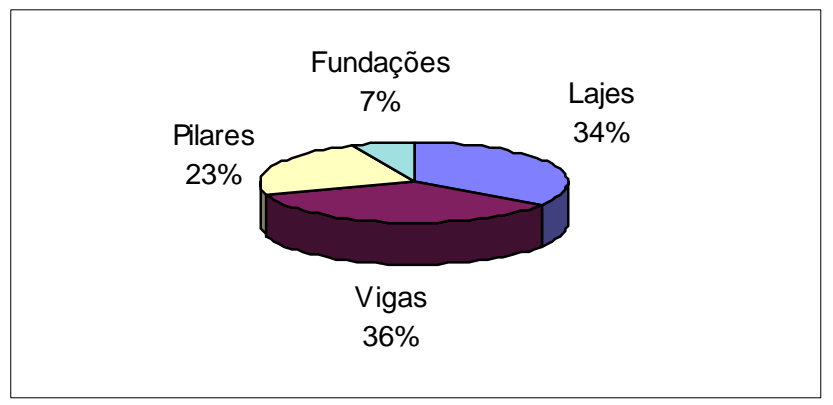

FIG. 8.8 - Custo percentual de cada elemento.

\subsubsection{EST. CONVENCIONAL COM LAJES NERVURADAS (CAIXOTES)}

\section{FUNDAÇÕES}

\begin{tabular}{|l|c|c|c|}
\cline { 2 - 4 } \multicolumn{1}{c|}{} & Qte. & P.Unit. $(\mathrm{R} \$)$ & P.Total $(\mathrm{R} \$)$ \\
\hline Concreto $\left(\mathrm{m}^{3}\right)$ & 79,24 & 126,00 & $9.984,24$ \\
\hline Aço $(\mathrm{kg})$ & 5.638 & 1,10 & $6.201,80$ \\
\hline \multirow{2}{*}{} & Total & $16.186,04$ \\
\cline { 2 - 4 }
\end{tabular}

CUSTO TOTAL (R\$) 233.267,5

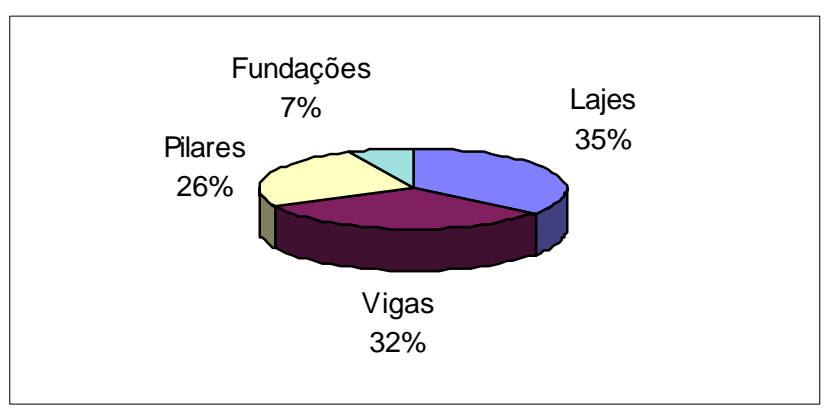

FIG. 8.9 - Custo percentual por elemento. 
8.2.3 EST. CONVENCIONAL COM LAJES NERVURADAS (TIJOLOS)

\section{FUNDAÇÕES}

\begin{tabular}{|l|c|c|c|}
\cline { 2 - 4 } \multicolumn{1}{c|}{} & Qte. & P.Unit. (R\$) & P.Total $(\mathrm{R} \$)$ \\
\hline Concreto $\left(\mathrm{m}^{3}\right)$ & 90,12 & 126,00 & $11.355,12$ \\
\hline Aço $(\mathrm{kg})$ & 6.387 & 1,10 & $7.025,70$ \\
\hline \multirow{2}{*}{} & Total & $18.380,82$ \\
\cline { 3 - 4 }
\end{tabular}

CUSTO TOTAL (R\$) 250.618,72

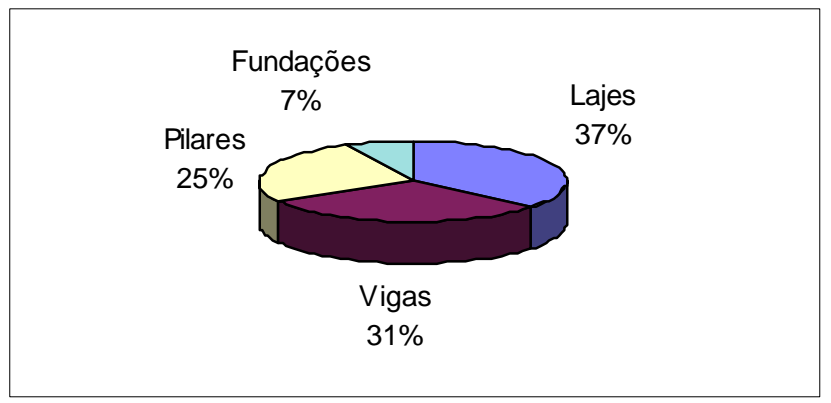

FIG. 8.10 - Custo percentual por elemento.

\subsubsection{EST. CONVENCIONAL COM LAJES NERVURADAS (PRÉ-FABRICADAS)}

\section{FUNDAÇÕES}

\begin{tabular}{|l|c|c|c|}
\cline { 2 - 4 } \multicolumn{1}{c|}{} & Qte. & P.Unit. (R\$) & P.Total $(\mathrm{R} \$)$ \\
\hline Concreto $\left(\mathrm{m}^{3}\right)$ & 81,32 & 126,00 & $10.246,32$ \\
\hline Aço $(\mathrm{kg})$ & 5.807 & 1,10 & $6.387,70$ \\
\cline { 3 - 4 } & & Total & $16.634,02$ \\
\cline { 3 - 4 }
\end{tabular}

CUSTO TOTAL (R\$) 244.758,1

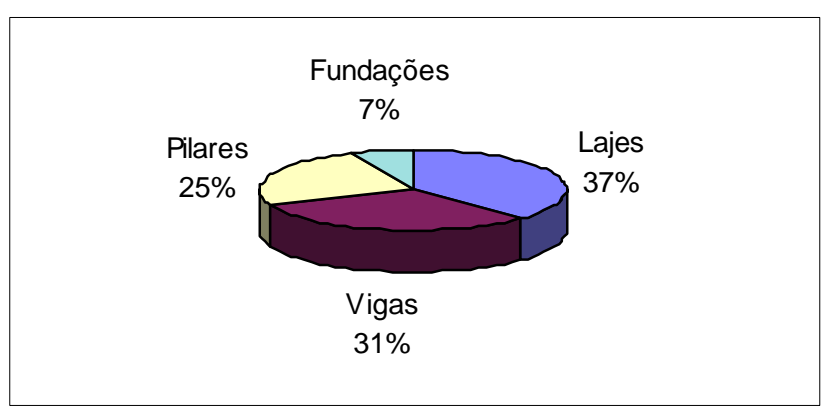

FIG. 8.11 - Custo percentual por elemento. 


\subsubsection{ESTRUTURA COM LAJE LISA NERVURADA (CAIXOTE)}

\section{FUNDAÇÕES}

\begin{tabular}{|l|c|c|c|}
\cline { 2 - 4 } \multicolumn{1}{c|}{} & Qte. & P.Unit. $(\mathrm{R} \$)$ & P.Total $(\mathrm{R} \$)$ \\
\hline Concreto $\left(\mathrm{m}^{3}\right)$ & 84,88 & 126,00 & $10.694,88$ \\
\hline Aço $(\mathrm{kg})$ & 6.044 & 1,10 & $6.648,40$ \\
\hline \multicolumn{2}{l}{} & Total & $17.343,28$ \\
\cline { 2 - 4 }
\end{tabular}

CUSTO TOTAL (R\$) 253.134,38

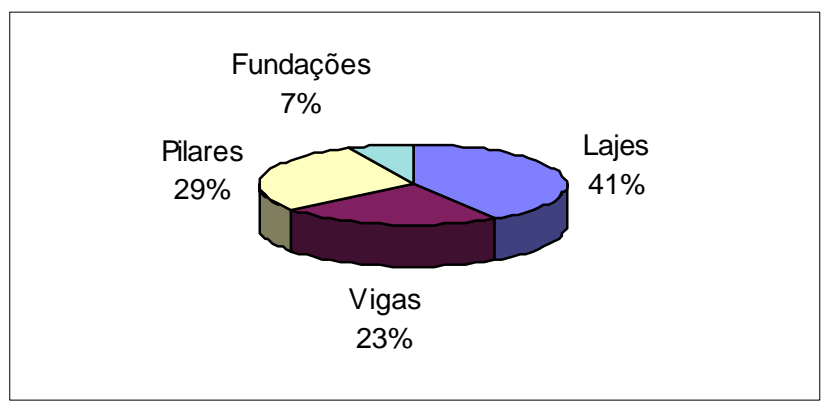

FIG. 8.12 - Custo percentual por elemento.

\subsubsection{ESTRUTURA COM LAJE LISA NERVURADA (TIJOLOS)}

\section{FUNDAÇÕES}

\begin{tabular}{|l|c|c|c|}
\cline { 2 - 4 } \multicolumn{1}{c|}{} & Qte. & P.Unit. $(\mathrm{R} \$)$ & P.Total $(\mathrm{R} \$)$ \\
\hline Concreto $\left(\mathrm{m}^{3}\right)$ & 88,51 & 126,00 & $11.152,26$ \\
\hline Aço $(\mathrm{kg})$ & 6.159 & 1,10 & $6.774,90$ \\
\hline \multirow{2}{*}{} & Total & $17.927,16$ \\
\cline { 3 - 4 }
\end{tabular}

CUSTO TOTAL (R\$) 267.278,96

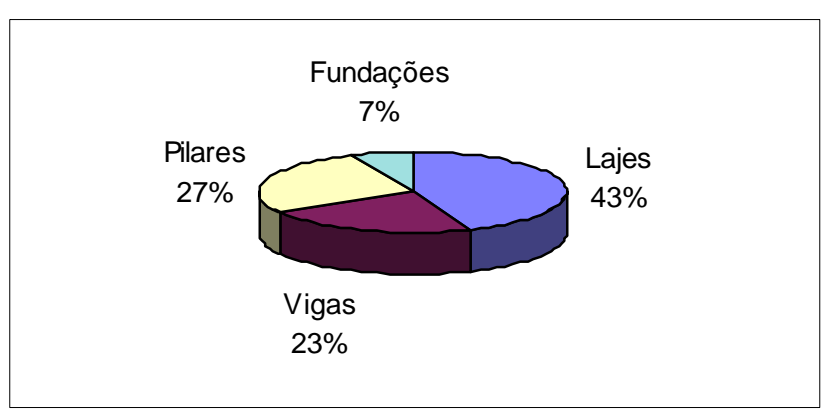

FIG. 8.13 - Custo percentual por elemento. 


\subsubsection{ESTRUTURA UTILIZANDO PROTENSÃO}

\section{FUNDAÇÕES}

\begin{tabular}{|l|c|c|c|}
\cline { 2 - 4 } \multicolumn{1}{c|}{} & Qte. & P.Unit. (R\$) & P.Total $(\mathrm{R} \$)$ \\
\hline Concreto $\left(\mathrm{m}^{3}\right)$ & 96,47 & 126,00 & $12.155,22$ \\
\hline Aço $(\mathrm{kg})$ & 6.552 & 1,10 & $7.207,20$ \\
\hline \multirow{2}{*}{} & Total & $19.362,42$ \\
\cline { 3 - 4 }
\end{tabular}

CUSTO TOTAL (R\$) 270.953,36

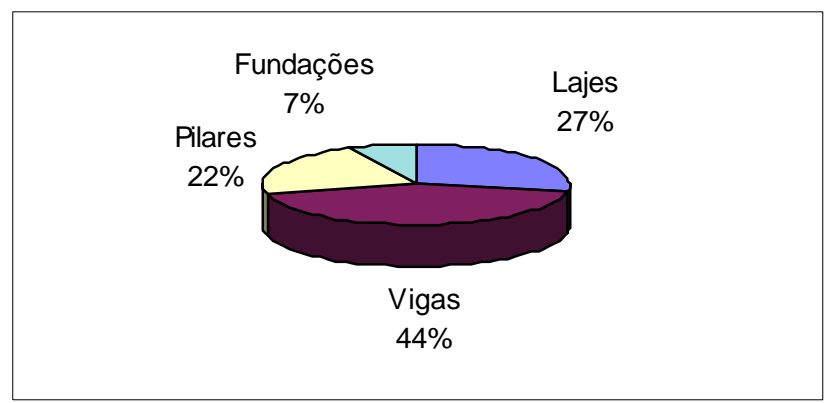

FIG. 8.14 - Custo percentual por elemento.

\subsection{COMPARATIVO DE CUSTOS}

A tabela 8.1 ilustra comparativamente os custos, com fundações, de todas as alternativas consideradas.

Tabela 8.1 - Tabela comparativa de custos com fundações (R\$).

\begin{tabular}{|c|c|c|c|c|c|c|}
\hline OP1 & OP2 & OP3 & OP4 & OP5 & OP6 & OP7 \\
\hline 273.812 & 233.268 & 250.619 & 244.758 & 253.134 & 267.279 & 270.953 \\
$(+17,4 \%)$ & $(1)$ & $(+7,4 \%)$ & $(+4,9 \%)$ & $(+8,5 \%)$ & $(+14,6 \%)$ & $(+16,1 \%)$ \\
\hline
\end{tabular}

Observa-se que com a inclusão das fundações os custos das opções aumentaram aproximadamente entre $7 \%$ e $8 \%$.

Observa-se ainda que as diferenças entre os custos das opções, em termos percentuais, praticamente não se alteraram com a inclusão das fundações. 


\section{CONCLUSÕES}

Ao se avaliarem custos de uma alternativa estrutural, não se deve levar em consideração somente os consumos de materiais e sim todos os aspectos pertinentes ao processo construtivo, tais como: mão-de-obra, tempo de execução, recursos e materiais necessários. Para uma avaliação mais completa, deve-se fazer, também, uma análise das implicações que cada alternativa acarreta nas instalações, nas alvenarias e nos tipos de forro.

A estrutura convencional com lajes maciças (OP1) apresentou o maior custo, e a grande quantidade de vigas dificulta a execução e prejudica a arquitetura. O uso desse sistema estrutural deve ser restringido a casos específicos.

A estrutura convencional com lajes nervuradas utilizando caixotes (OP2) foi a mais econômica, apresentando uma redução de $15,15 \%$ em relação à alternativa OP1. Esse sistema estrutural é muito recomendado para edifícios similares ao edifício-exemplo e vem sendo muito utilizado na maioria das cidades brasileiras.

A estrutura convencional com lajes nervuradas utilizando tijolos (OP3) apresentou uma redução de 9,23\% em relação à alternativa OP1. Tem a vantagem do teto pronto, não necessitando de forro.

A estrutura convencional com lajes nervuradas utilizando préfabricados (OP4) apresentou uma redução de 10,84\% em relação à alternativa OP1, tendo como vantagens: teto pronto e rapidez de execução.

As estruturas com laje lisa (OP5 e OP6) apresentaram uma redução de custos em relação à alternativa OP1 de: 7,84\% (caixotes, OP5) e 2,54\% (tijolos, OP6). Essas alternativas trazem a vantagem da grande flexibilidade do pavimento, devido à ausência de vigas internas. Essa flexibilidade é muito indicada para edifícios que necessitem de variações de paginação entre os apartamentos, 
edifícios sofisticados com um único apartamento por pavimento ou edifícios com pavimentos muito distintos, como por exemplo hospitais e empresas.

A estrutura utilizando protensão (OP7), embora apresente uma redução de apenas $1,67 \%$ em relação à alternativa OP1, é um sistema estrutural bastante promissor, pela flexibilidade dos pavimentos e pelo número reduzido de pilares. Há uma tendência de diminuição dos custos de protensão (que representaram $12 \%$ do custo total), caso haja maior utilização desse sistema. Ele pode ser bastante competitivo para pavimentos com grandes vãos, sem colunas intermediárias, grande flexibilidade de utilização e "layouts" variados.

Muitos construtores argumentam que a flexibilidade do pavimento, apresentada nas alternativas OP5, OP6 e OP7, é um forte apelo comercial para a venda dos apartamentos, já que facilita ao proprietário modificações no seu imóvel.

Nas duas alternativas em que os caixotes foram substituídos por tijolos (OP2 $\rightarrow$ OP3 e OP5 $\rightarrow$ OP6), o custo subiu em média $6 \%$.

Nas estruturas sem recortes (OP5, OP6 e OP7) o custo das formas foi aproximadamente $20 \%$ do custo total, enquanto que nas estruturas com recortes (OP1, OP2 e OP3) o custo da forma foi de aproximadamente $30 \%$ do custo total, com exceção da alternativa utilizando lajes pré-fabricadas (OP4), em que o custo da forma foi de apenas $15 \%$ do custo total.

Observou-se que, com a inclusão das fundações, as diferenças percentuais entre os custos das alternativas não apresentaram variações significativas. Isso porque em todas as alternativas o acréscimo dos custos teve pequena variação, ficando entre $7 \%$ e $8 \%$ aproximadamente.

Por fim, volta-se a repetir que a escolha do sistema estrutural depende de muitas variáveis; algumas fogem da competência do engenheiro de estruturas, inclusive. Há ainda o aspecto em que o projeto de arquitetura pode inviabilizar um determinado sistema estrutural, devido a suas particularidades e imposições. Por isso, este trabalho não tem a intenção de generalizar os resultados aqui apresentados, mas se bem extrapolados podem auxiliar na estruturação de edifícios semelhantes. 


\section{REFERÊNCIAS BIBLIOGRÁFICAS}

AALAMI, B.O. (1989). Design of post-tension floor slabs. Concrete International: Design \& Construction, June.

AALAMI, B.O. (1990). Load balancing. ACl Structural Journal, v.87, n.6, NovemberDecember.

AALAMI, B.O. (1994). Unbonded and bonded post-tensioning systems in building construction. Phoenix, Pti Technical Notes, September.

ANDRADE, J.R.L. (1982). Estruturas correntes de concreto armado. São Carlos, EESC-USP.

ASSOCIAÇÃO BRASILEIRA DE ENGENHARIA E CONSULTORIA ESTRUTURAL (1998). A revolução nos custos. ABECE informa, n.15. São Paulo.

ASSOCIAÇÃO BRASILEIRA DE NORMAS TÉCNICAS (1980). NB-5/80 - Cargas para o cálculo de estruturas de edificações. Rio de Janeiro.

ASSOCIAÇÃO BRASILEIRA DE NORMAS TÉCNICAS (1987). NB-599/87 - Forças devidas ao vento em edificações. Rio de Janeiro.

ASSOCIAÇÃO BRASILEIRA DE NORMAS TÉCNICAS (1989). NB-116/89 - Projeto de estruturas de concreto protendido. Rio de Janeiro.

ASSOCIAÇÃO BRASILEIRA DE NORMAS TÉCNICAS (1978). NB-1/78 - Projeto e execução de obras de concreto armado. Rio de Janeiro.

ASSOCIAÇÃO BRASILEIRA DE NORMAS TÉCNICAS (1997). Revisão da NB-1 e comentários.

BARBIRATO, C.B.C. (1996). Contribuições a análise de pavimento de edifício em laje nervurada. São Carlos. Dissertação (Mestrado) - EESC - USP.

BAPTISTA, S.M. (1994). Análise de pavimentos de edifícios com a utilização do método dos elementos finitos. São Carlos. Dissertação (Mestrado) - EESC USP.

BOCCHI JUNIOR, C.F. (1995). Lajes nervuradas de concreto armado. São Carlos.

Dissertação (Mestrado) - EESC - USP.

BORGES, J.U.A. (1997). Critérios de projeto de lajes nervuradas com vigotas préfabricadas. São Paulo. Dissertação (Mestrado) - POLI - USP.

BRANCO, A.F.V.C. (1989). Contribuição para o projeto de lajes-cogumelo. São Carlos. Dissertação (Mestrado) - EESC - USP. 
BRANDÃO, A.M.S. et al. (1997). Lajes lisas protendidas: método das cargas balanceadas. In: JORNADAS SUL-AMERICANAS DE ENGENHARIA ESTRUTURAL, 28., São Carlos, 1997. Estruturas e fundações. São Carlos, EESC-USP/ASAEE, 1997, v.3, p. 1237-1246.

CAUDURO, E.L. (1997). Em favor da leveza. Téchne, n.26, janeiro/fevereiro.

CORRÊA, M.R.S. (1991). Aperfeiçoamento de modelos usualmente empregados no projeto de edifícios. São Carlos. Tese (Doutorado) - EESC USP.

CORRÊA, M.R.S. ; RAMALHO, M.A. Cálculo de pavimentos de edifício utilizando-se 0 método dos elementos finitos. In: JORNADAS SUDAMERICANAS DE INGENIERIA ESTRUCTURAL, 26., Montevideo, Uruguay, 15-19 nov. 1993. Memorias. Montevideo, CLAES/ ASAIE, 1993. v.1, p.109-120

COSTA, O.V. (1997). Estudo de alternativas de projetos estruturais em concreto armado para uma mesma edificação. Fortaleza. Dissertação (Mestrado) - UFC.

FIGUEIREDO FILHO, J.R. (1989). Sistemas estruturais de lajes sem vigas: subsídios para o projeto e execução. São Carlos. Tese (Doutorado) - EESC USP.

FORMPLAST (1998). Encarte técnico. Fortaleza.

FRANCA, A.B.M.; FUSCO, P.B. (1997). As lajes nervuradas na moderna construção de edifícios. São Paulo, AFALA \& ABRAPEX.

GASPAR, R. (1997). Análise da segurança estrutural das lajes pré-fabricadas na fase de construção. São Paulo. Dissertação (Mestrado) - POLI - USP.

LARANJEIRAS, A.C.R. (1995). Execução de projetos de estruturas de concreto armado, de edifícios. Norma interna da Construtora Suarez.

LIMA, J.C.O. (1993). Sistema treliçado global. Noticiário Mediterrânea n. 1. Boletim técnico.

MELGES, J.L.P. (1995). Punção em lajes: exemplos de cálculo e análise teóricoexperimental. São Carlos. Dissertação (Mestrado) - EESC -USP.

MOTA, J.E. (1998). Protensão não aderente com monocordoalhas engraxadas. /Palestra no auditório da Federação das Indústrias do Estado do Ceará, janeiro/ PRADO, J.F.A. (1995). Estruturas de edifícios em concreto armado submetidos a ações verticais e horizontais. São Carlos. Dissertação (Mestrado) - EESC - USP. 
PRELORENTZOU, P.A.; GIORGI, R.C. (1994). Diretrizes para projetos em lajes planas nervuradas. Norma da Construtora ENCOL.

PRELORENTZOU, P.A.; GIORGI, R.C. (1994). Critérios e parâmetros de projetos estruturais de edificações . Norma da Construtora ENCOL.

\section{BIBLIOGRAFIA COMPLEMENTAR}

AALAMI, B.O. (1994). Strength evaluation of existing post-tension beams and slabs analytical approach. Phoenix, Pti Technical Notes, March.

ARDUINI, A.M.V. (1991). Algumas diretrizes para a elaboração de um projeto de estruturas em concreto armado. Dissertação (Mestrado) - EESC - USP.

CARMO, R.M.S. (1995). Efeitos de segunda ordem em edifícios usuais de concreto armado. São Carlos. Dissertação (Mestrado) - EESC - USP.

CARVALHO, R.C. (1994). Análise não linear de pavimentos de edifícios de concreto armado através da analogia de grelhas. São Carlos. Tese (Doutorado) - EESC - USP.

FRANÇA, R.L.S. (1991). Contribuições ao estudo dos efeitos de segunda ordem em pilares de concreto armado. São Paulo. Tese (Doutorado) - POLI - USP.

FRANCO, M. O. (1985). Parâmetro de instabilidade dos edifícios altos. Revista Portuguesa de Engenharia de Estruturas, Lisboa, n. 23.

FUSCO, P.B. (1976). Fundamentos do projeto estrutural. São Paulo, McGraw-Hill.

FUSCO, P.B. (1981). Estruturas de concreto: solicitações normais. Rio de Janeiro, Guanabara Dois.

FUSCO, P.B. (1994). Técnicas de armar as estruturas de concreto. São Paulo, Pini. GUARDA, M.C.C. (1995). Cálculo de lajes-cogumelo pela teoria das charneiras plásticas. São Carlos. Dissertação (Mestrado) - EESC - USP.

LEONHARDT, F. (1977). Construções de concreto. Rio de Janeiro, Interciência. v.1-4

MONTOYA, P.J.; MESEGUER, A.G.; CABRÉ, F.M. (1987). Hormigón armado. Barcelona, Gustavo Gili. v.1

SUSSEKIND, J. C. (1993). Curso de concreto: concreto armado. São Paulo, Globo. 2v. 